STATE OF ILLINOIS

DEPARTMENT OF REGISTRATION AND EDUCATION

DIVISION OF THE

NATURAL HISTORY SURVEY

STEPHEN A. FORBES, Chief

Vol. XVII. BULLETIN $\quad$ Article II.

\title{
A Manual of Woodlot Management
}

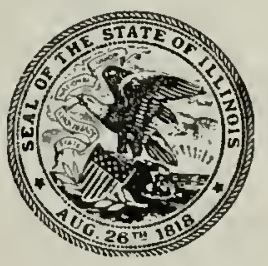


STATE OF ILLINOIS

DEPARTMENT OF REGISTRATION AND EDUCATION

A. II. Sheltox. Direetor

BOARD OF

NATURAL RESOURCES AND CONSERVATION

A. M. Sheltox, Chairman

William Treiease, Biology

Hexry C. Cowles, Forestry

Edson S. Bastin. Geology

Whtiant A. NoYes, Chemistry
JoHs W. Alvois. Engineering

Citarles M. Thompson, Representing the President of the University of Illinois

THE NATURAL HISTORY SURVEY DIVISION

STEPHEN A. Forbes, Chief

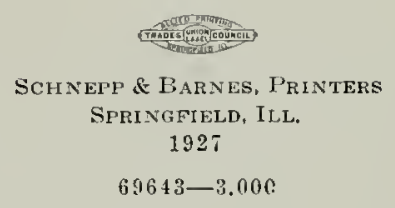




\section{CONTENTS}

P.IGE

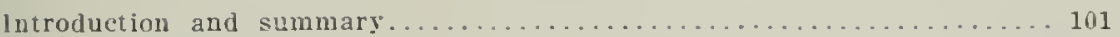

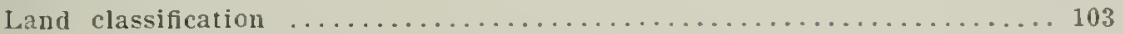

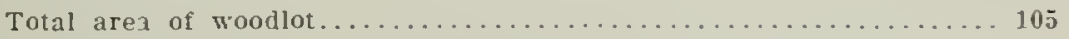

The woodlot as a source of fuelwood, posts, and lumber for the farm... 105 (Table I, Requiled renewals of untreated pusts, p. 106 )

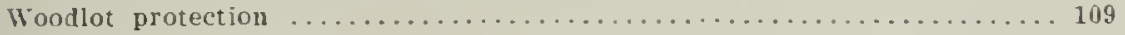

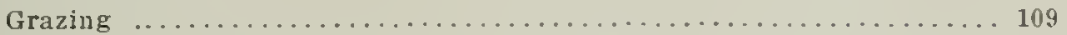

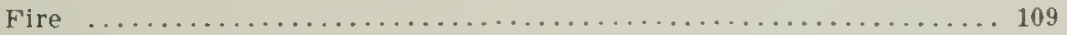

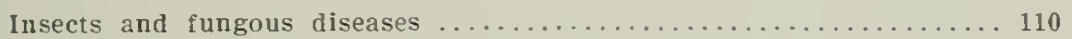

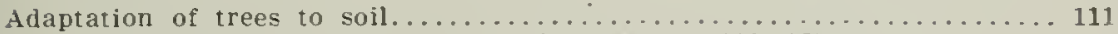

(Tables 11-T]J, Average growth rates, piv. 11:-11\%)

(Table TJI, Lists of species recommended, pi). 115-122)

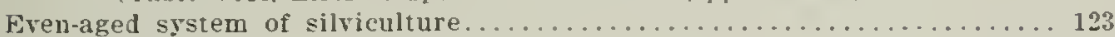

Development of an even-aged stand.......................... 125

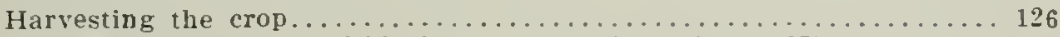

(Table 1. Average vields from tren-aged stands, p, 127)

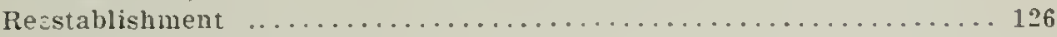

Regeneration from sprouts......................... 126

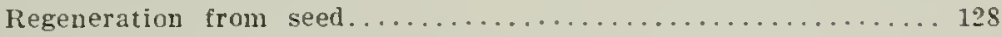

Application of the even-aged sys en ......................... 129

Species suitable for production of piling.................. 129

Intolerant species, exemplified by cottonwood............... 129

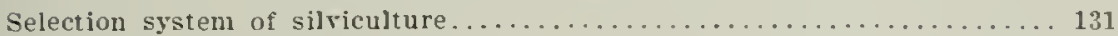

General cultural measures............................ 131

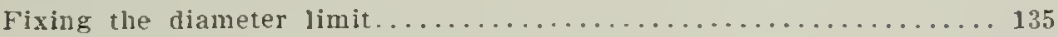

Advantage of larger diameters......................... 135

(Table $K$, Yields of ties per acre under vatum diameter limits, p. 13i)

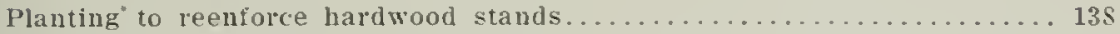

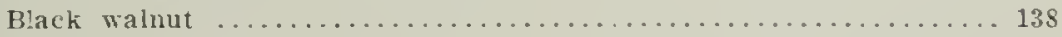

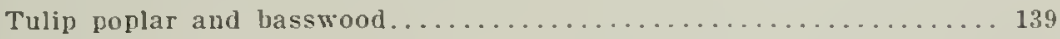

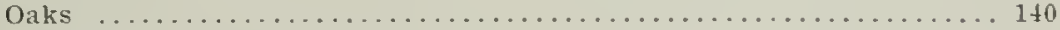

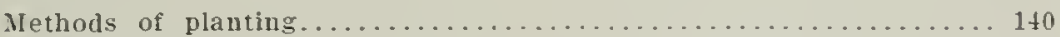

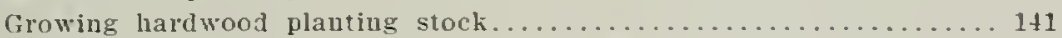

(Table XJ, Number of seeds to sww (1) secare 15 hardwood seedlings to the foot, p. 141)

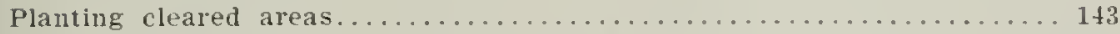

Comnercial aspects of reforesting cleared land ............... 143

Plantations for production of sam-logs.......................

Growing coniferous planting stock...................... 145

(Table XIl. Number of seeds to sow in secure 100 conifer seedlings per sujuate foot, p. 145)

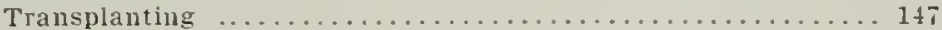

Conifer plantations on sands........................ 14S 
PAGE
PAG

Conifer plantations on loans........................ 150

Christmas tree plantations.................... 150

Cottonwood plantations on bottomlands............... 152

(Table XIII, Yield per acre for fully-stocked cottonwood, p. 155)

Period for most profitable harvest................ 156

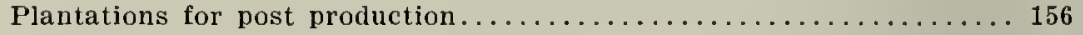

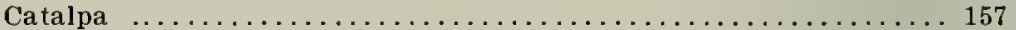

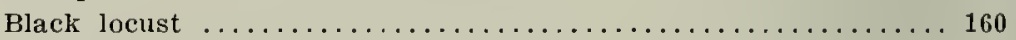

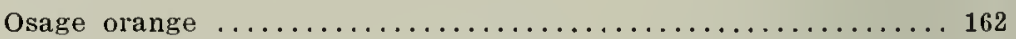

Summary of points on seed and tree planting. . . . . . . . . . . 163

Measuring and marketing woodlot products................. 164

Choice of prodncts.......................... 164

(Table XIV, Shipping distances determined by the margin between

average sale price and average manufacturing cost, p. 166)

(Table XV, Net returns per acre as influenced by kind of product and shipping distance, D. 167 )

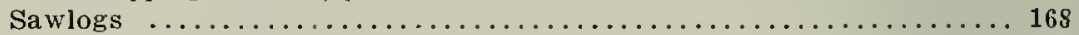

Estimating standing timber................... 168

(Table XVI, Average thickness of bark for black oak, p. 171)

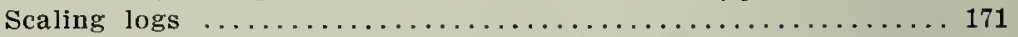

(Table XVII, Board-foot contents for logs of given diameters and

lengths as scaled by the International rule and by the Doyle rule, p. 172)

Markets, specifications, and quotations............... 172

Lumber $\ldots \ldots \ldots \ldots \ldots \ldots \ldots \ldots \ldots \ldots \ldots \ldots \ldots \ldots \ldots \ldots \ldots \ldots \ldots \ldots \ldots \ldots$

(Table XV111, Approximate weights of various wood products, p. 174)

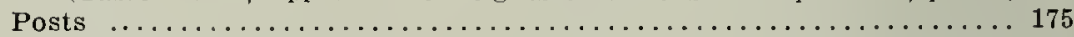

Ties $\ldots \ldots \ldots \ldots \ldots \ldots \ldots \ldots \ldots \ldots \ldots \ldots \ldots \ldots \ldots \ldots \ldots \ldots \ldots \ldots \ldots \ldots$

(Table XIX, Yield in ties of various grades for trees of given diameter

and height, p. 176)

(Table $\mathbf{X X}$, Valnes of ties, based on average quotations, p. 177)

Piling . . . . . . . . . . . . . . . . . . . . 177

(Table XXI, Approximate weights of piling of different sizes, green

and dry, for different kinds of wood, p. 178)

Mine timbers $\ldots \ldots \ldots \ldots \ldots \ldots \ldots \ldots \ldots \ldots \ldots \ldots \ldots \ldots \ldots \ldots \ldots \ldots \ldots$

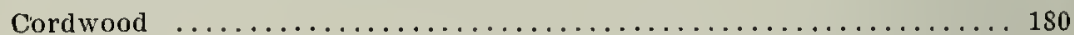

(Table XXII, Number of trees required to yield one cord, p. 1so)

Appendices-

A. Preservative treatment of fence posts................. 181

B. List of concerns dealing in tree seedlings and transplants.......183

C. List of consnmers and dealers (arranged by counties) ......... 184

D. United States Department of Agriculture publications relating to woodlot management and tree culture................ 192

E. lllinois State Natural History Survey publications on forestry... 193

F. Services offered to woodland owner's by Illinois State Natural History Snrvey ............................ 194 


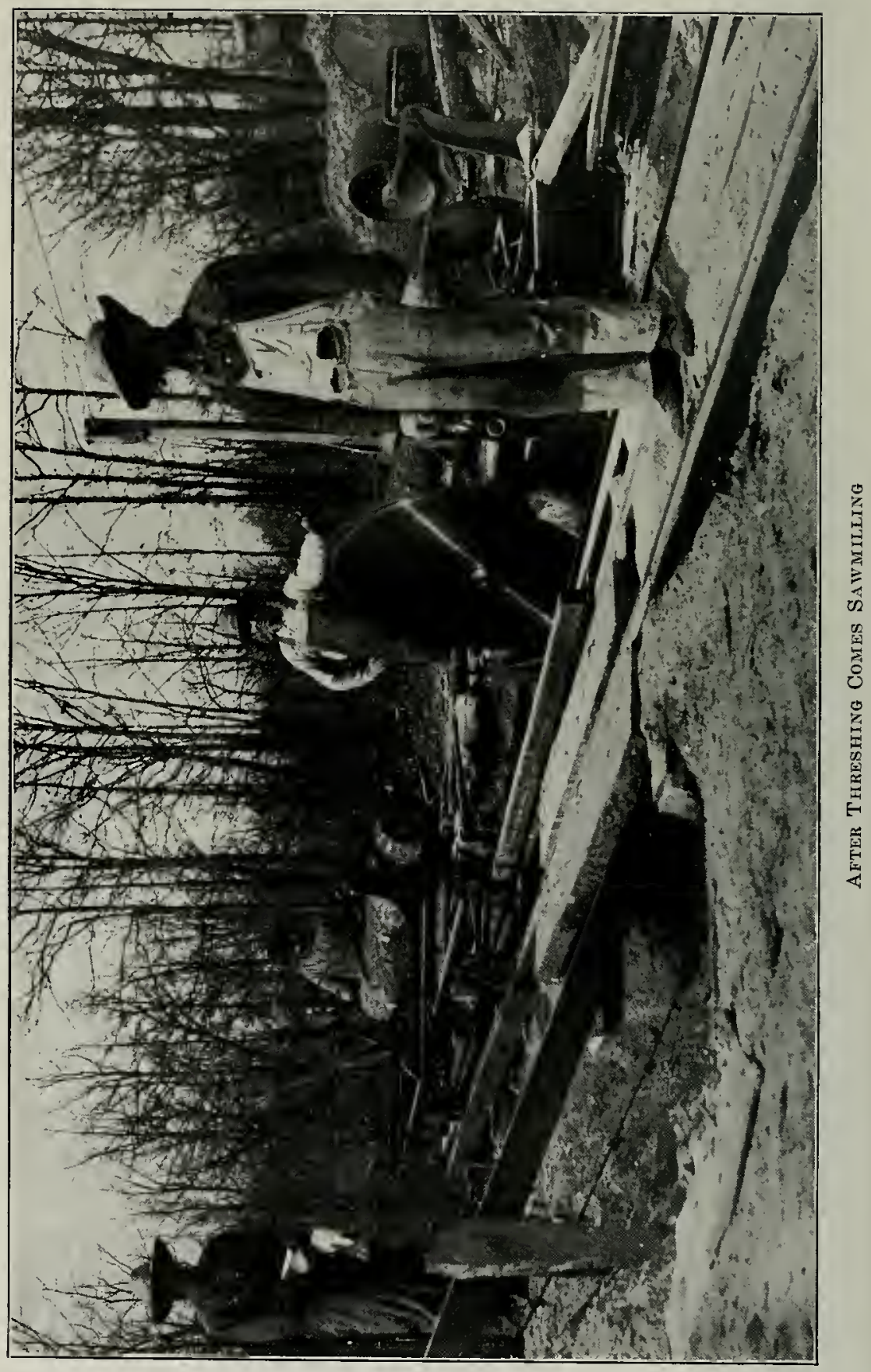




\section{A MANUAL OF WOODLOT MANAGEMENT}

\section{J. TELFORD}

This manual is adrlressed to those landowners who have woodlots or idle land. It is assumed that they appreciate the intangible benefits accruing from the woodlot as a refuge for wild life, as a local modifier of dry and cold winds. as a protection to the sources of local water supply, as a means of enhancing the beauty of the landscape, and as a place for recreation; and that they also appreciate the service to the nation rendered by productive forests. Our purpose is to define the true forest lands in Illinois, to outline the methods for the proper management of the woodlot, and to give the general returns to be derived from the managed production of wood. The point of view throughout is the growing of a wood crop as a producer of revenue. The broad essentials of woodlot management are outlined briefly, the methods which are adapted to the growing of timber nnder different conditions of site and market are discussed at some length, and the methods of measuring and marlieting the product are described in detail.

\section{Summary of Gexeral Meastres tx the Maxagenext OF NATERAL IVOOHLOTS}

The broad essentials of woodlot management may be summarized as follows:

(1) Put the soil in condition to support the best growth by developing and maintaining a good leaf mulch. Since fire, grazing, wind, and sunshine destroy this mulch. keep out fire by eternal rigilance, stock by fencing. wind by leaving a lense wall of bushes on the borders and snall trees within the woods, and sunshine by growing enough trees to provide a complete shade.

(?) Stock the area with the most rapidly growing species suited to the products in view. In Table 1111 (page 118 ) are linted the species recommended for the specified products under definite soil conditions. Work out the worthless trees, such as decayed. broken-topped, crookedor short-boled, very limby ones of all species. and all trees of those species classed as weed trees and listed on page 11s. Observe the seed bed conditions which favor the seeding in of trees of the species desiredshade or sunlight, leat litter, humus or mineral soil-and create such 
conditions at the time when the desired species promises to bear good seed crops. If suitable restocking can not be attained naturally, plant seeds or small trees where reenforcement is necessary.

(3) Develop and maintain light conditions favoring the rapid growth of trees of good form. Enough trees should be grown so that tall clear-boled trees are produced. This type is secured when the trees during their early stages of development get direct sunlight only from overhead and none on the lower branches. This crowding, intendect to force the tree to discard the lower limbs, must be done when the trees are young. The naturally pruned tree should be so developed as to show a tall straight stem, with the crown bunched at the top when it has attained a diameter of 6 to 10 inches and is passing the period of most rapid height growth. After this period, there will be progressively less stem added to the top from which branches can grow, and continued crowding cramps the crow1s. At this stage, therefore, thinnings should be initiated to stpply space for lateral crown expansion. Such thinnings should be light, removing just enough live trees to give the select trees the space which they will fill up in five or six years. When crowding again occurs, another thinning is made. In even-aged stands, these thinnings can be done somewhat systematically at regular intervals. In an all-aged stand containing trees of different sizes, the process of regeneration, the crowding of immature trees to improve their form, thinnings to give additional space to the crowns of select trees, and cuttings incident to harvesting the crop, are carried on simultaneously.

Very frequently one operation can be carried out only by sacrificing some of the rules outlined. If a raw mineral soil is necessary for seedling regeneration, obviously the heavy leaf mulch can not be retained; if undesirable trees have usurped a large part of the area. these can not be removed without letting in sunlight; if the underbrush consists of weed trees, its removal gives access to the wind. In forest management, judgment rather than rules must be followed. 


\section{LAND CLASSIFICATION}

Land is classified according to its suitability for certain uses. The guiding principle usually is that lands slould be put into the most productive gromp to which they lend themselves. Permanent classification is impossible-the swamp of yesterday, if drained, becomes productive cropland 10-day, and may be the site of a town to-morrow-but at present almost nine-tenths of the area of Illinois is given over to the business of farming, so that a classification based upon the use of land for farming applies to practically all of the State.

The farm owner generally classifies his land by answering two questions: (1) Does the land lie so that cropping is possible? (?) Is the quality of the soil good enough to raise paying crops: Any part of the farm which seems unlikely to produce crops at a profit is left in forest or is consiclered waste land. Some areas are molereloped because they do not lie so that cropping is possible. The slopes may be too steep for tillage or they may be badly gullied. Similarly. roch-strewn fields disconrage cultivation. Other areas are not farmed lecanse the quality of the soil is not good enough to raise paying crops. This class includes extremely compact hatdpan soils, extremely loose sandy soils. worn-out cropiands, and soggy bottomlands. Some of this non-cropned land is potential cropland in the sense that by terracing. ly draining. or by soil treatment it can be developed to prodnce crojs. bit there is no reason to believe that the economic conditions which have forced a decrease in the cropland area in Illinois during the past $1 . j$ rears will improve enough to make profitable the immediate redemption of these marginal lamls. The steep hillsides. gullien. rocky, or worn-ont fields, sands, hardpan soils, swamps, and flood hottoms. it is generally agreed. should be in forests.

From the viewpoint of the production of wood at a profit. this definition of the true forest lands is inaccurate. There are lands in the above list which can not produce any hind of wood crops at a profit, and there are certain lands now returning a profit in crops which would show a higher profit from forests. The farmer can not get a profitable wood crop from all lands too poor for general crops. nor does lye need to confine his woodlot to areas unsuited to other crops.

Considering. first, the lands listed above as matuced to ordinary tarm crops, we find that the revenue to be derived from either natural or planted forests on the hardpan soils (post oak flats) is less than the cost of management: that sancls can unually produce acceptable timber crops only when jlanted to conifers: that the loams on steep slopes and on gullied, rocky. or worn-out fields ustually prove acceptable for either native hardwoods or conifers: and that the floodlands are well suited to hardwoods. 
Considering, next, the arable lands which are commonly considered as true croplands, we find that wood production is financially justifiable on such lands only when the sustained net returns from wood crops equal or exceed those from other crops which can be produced on them. There is very little conflict between wood crops and other farm crops on high-grade arable land. Asirle from very linited areas devoted to fence post or Christmas tree plantations, such land can not produce returns from wood crops comparable to those from the ordinary farm crops, and it should not be in woorls. Low-grade arable land and unimproved pasture return net revenues comparable to those from productive forests. The net returns from the rough hillside pasture averages about \$1.25 per acre annually. The same kind of land in wellstocked hardwood forests yields a net retu11n up to $\$ 1.60$ per acre anntially. Certainly, there is no econonic justification for developing a pasture or low-grade cropland where woods are already well established and will give a better return, but, if they are once cleared, the very considerable cost of forest restoration more than offsets the higher revenue accruing from the forest. Keej such forested land in forest. The time has not yet come in Illinois when land already cleared, suitable for and devoted to untilled pasture, will give sufficiently greater returns if restored to forest to justify the change; and such land, therefore, should te kept in pasture.

The detailed classification of farm land to determine the area of true forest land is most important and often difficult. Very steep hillsides or frequently flooded bottomland can readily be classified as forest land, just as well-located, fertile prairie loams fall into the division of true arable soils. The need of information which can be used in classifying the marginal soils between these extremes becomes apparent in the survey of the farm.

Should any of the improzed lands be given over to forest? A proper system of accounting will show if the field in question is giving a net return. Lacking such records the classification becomes a matter of guesswork and is seriously liable to error.

What slopes are too stecp for cultivation? The erosion of a given area is dependent upon the volume of water passing over it, the velocity which the water attains, and the character of the soil. The amount of water is influenced by the area drained and by the structure of the soil and soil cover, and the velocity is determined by the gradient. Heavy, compact clays absorb but little water and, when stripped of cover, readily wash at gradients as low as $6^{\circ}$ in Hardin County. The open, absorbent, deep loess soils in parts of Jackson County produce alfalfa on slopes greater than $20^{\circ}$ without eroding; yet the open mixed sand and loess soils in parts of Whiteside Comnty gully seriously when cleared. 
These instances are advanced to slow that no fixed ruling about degree of slope can be given*. If erosion has developed to such an extreme stage that gullies are forming, the land is true forest land; but areas n1ay be in this class where erosion has not reached the gully phase. Actually less loss to farm soils results from gullying than from a general surface washing resulting in the steady renoval of the surface soil particles, the consequent impoverishment of the soil, and the relegation of the area to the worn-ont crop-land class. The effect on the soil of this surface washing is much more ruinous than is generally appreciated and reduces the fertility of soils to a greater degree than the denlands of the crops for plant food. Thus arable slopes which do not gully may becone true forest areas because they no longer produce profitable crops, and the classification is dependent upon crop recoris and costs.

\section{Total. Area of IVOODLot}

Careful classification of the land on a given farnu may slow both wooded areas and cleared areas which should be forested. The total of these areas of true forest land 11aturally varies for individual farms. If the woodlot comprises all non-arable parts of the farm, it is eviclent that its size may bear little relation to the needs of the farm. The first aim in woodlot management, however, should be to supply the farm with those products which can be grown in the woodlot. In many 111stances the woodlots will also produce a surplus, and they must be managed with a view to marketing this surplus in the most profitable form.

\section{THE WOODLOT AS A SOURCE OF SUPPLY FOR THE FARII}

The wood consumed on farms in Illinois consists largely of fuelwood, posts, and lumber; it averages, as standing timber, 704.8 cubic feet per farm annally. The average rate of growth for fully-stocked stands is estimated at 41.1 cubic feet per acre annully, and the area of the woodlot required to supply this wood to an average farm is 17.1 acres.

Cousidering these three major forms of wood used, the woodlot sliould in all cases supply the posts used on the farm; it should in most cases furnish the lumber: and it sbould supply the fuelwood only when this call be secured by utilizing tops aud other materials which can serve no higher purpose. White oak fence posts cost on an average $\$ 0.24$ each, and an average acre should produce $3 S$ posts annually, a total value of $\$ 9.12$. The farm woodlot can usually supply all the rough lumber used on the farm. The operator will be dependent upon outside sources for the bulk of the surfaced lumber; for, although the woodlands of Illinois will produce crops of pine and other woods suitable for

* For a discussion of erosion see Circular No. 290. "Saving Soll by Lse of M7ngum Terraces", and Bulletin No. 207. "Washing of Soils and Methods of Prevention", Lniversity of lllinnis Agricultural Collegt and Experiment Station. 
finished lumber, the process of manufacturing into siding, flooring, ceiling and similar finished products requires equipment not available to the woodlot owner. The fully-stocked average acre in Illinois should produce an average of 180 board feet of hardwoods annually, having a gross value of $\$ 8.10$. The production of fuelwood as the chief crop is not an economical use of forests. To supply annually wood equivalent to one ton of coal requires nearly $2 \frac{1}{2}$ acres of average woodland. With an average cost of coal of $\$ 6.60$ per ton, the gross returns from such woodland devoted to cordwood are but $\$ 2.71$ per acre annually. No greater mistake is commonly made than converting into cordwood the timber which is suitable for higher uses.

The following information is given for the benefit of the woodlot owner who wishes to compute the woodlot area required to supply his farm. He may calculate from Table I the number of posts which will be needed annually to keep up his fences.

TABLE I

Requireb Rexewals of UNtreated Posts *

\begin{tabular}{|c|c|c|c|}
\hline Species & $\begin{array}{l}\text { Number of untreated } \\
\text { posts that must be } \\
\text { renewed annually } \\
\text { in each } 100 \text { posts } \\
\text { in tence }\end{array}$ & Species & $\begin{array}{l}\text { Number of untreated } \\
\text { posts that must be } \\
\text { renewed annually } \\
\text { in each } 100 \text { posts } \\
\text { in fence }\end{array}$ \\
\hline $\begin{array}{l}\text { Osage orange } \ldots \\
\text { Mulberry } \ldots . . . \\
\text { Black locust } \ldots \\
\text { Catalpa } \ldots \ldots \ldots \\
\text { Cedar } \ldots \ldots \\
\text { Burr oak } \ldots \ldots \ldots \\
\text { Post oak } \ldots \ldots \\
\text { Walnut ...... }\end{array}$ & $\begin{array}{l}21 / 2 \\
5 \\
5 \\
62 / 3 \\
62 / 3 \\
8 \\
9 \\
9\end{array}$ & 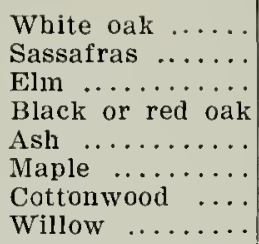 & $\begin{array}{l}10 \\
11 \\
16 \% \\
20 \\
20 \\
221 / 5 \\
281 / 2 \\
281 / 2\end{array}$ \\
\hline
\end{tabular}

* From Second Report on a Forest Suvey of Illinois. State Natural History Survey Bulletin Vol $\mathrm{XV}$, Art. III (1924).

Each post is equivalent to 1.08 cubic feet in the standing tree. To get the total cubic feet required for posts, find from Table $I$ the number required annually and multiply by 1.08 . To get the total cubic feet required for rough lumber,divide the annual board feet requirements by 4.4 . There will be approximately one cord of fuelwood in the tops for each 1000 B. F. of lumber taken out.

If additional fuel wood is cut, the ansount in cubic feet is found by multiplying by $s 0$ the number of additional cords required.

The average annual growth in peeled stems for fully-stocked woodlots is as follows: 
Upland

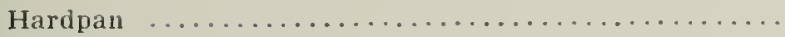

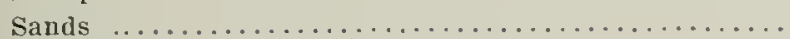

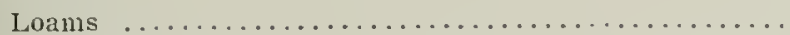

Bottomland

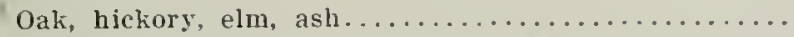

Sycamore, soft maple, cottoumood, sweet gum, jocust...

To find the approximate number of acres required to supply the farm. first find the total number of cubic feet required and then divide by the average annual growtl per acre of the type in question.

Example: Assmme that the farm has 135 acres with a total of 544 posts. If the posts are white oak, there are required for renewals 10 posts for each 100 in service (Table I), or S5 posts yearly. Each post is equivalent to $1.0 \mathrm{~S}$ cubic feet of standing timber, so that the annual drain on the woodlot for post material is $\$ 5 \times 1.08$, or 92 cubit feet.

Assuming that the consumption of rough lumber ou the farm is $1000 \mathrm{~B} . \mathrm{F}$. annualy: and that there are $4.4 \mathrm{~B} . \mathrm{F}$. in each cubic foot of the standiug tree, then the drain on the woodlot for $n$ mb ${ }^{\circ} r$ is 1.000 divided by 4.4 or 228 eubic feet.

Assume that, in addition to the cord of fuelwood in the tops of the trees cut for sawlogs, there are cut 4 more cords per year. Eacl cord is equivalent to 80 cubic feet; hence, this drain for fueluood equals 4 times 80 . or 320 cubic feet.

The total anmua] drain is then to be calculated thus:

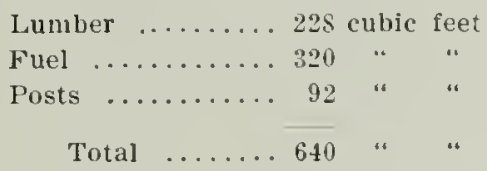

If the woodlot is entirely on the hardpan soils. only fuel and posts can be produced. To supply the 412 cubic feet needed for these, requires $\frac{412}{15.5}$. or 26.1 acres.

If the woodlot is on sands, the fuel. lumber, and post requirements of 640 cubic feet can be supplied by $\frac{640}{28.6}=22.4$ acres.

Similarly, on the upland loams the requirements will be met by using $\frac{640}{36.4}$ $=17.6$ acres; the oak, hickory, elm, ash bottomland type, by using 640 45

type, by using $\frac{640}{100}=6.4$ acres. The gross value of the $1,000 \mathrm{~B}$. F. of lumber, 5 cords of wood, and $\$ 5$ posts is approximately \$42. so that the woodlot on sand gives a gross return of $\$ 4.10$ per acre annually, the upland loam type $\$ 5.23$, the slow-growing bottomland type $\$ 6.48$, the rapidly-growing bottomland type $\$ 14.35$. 


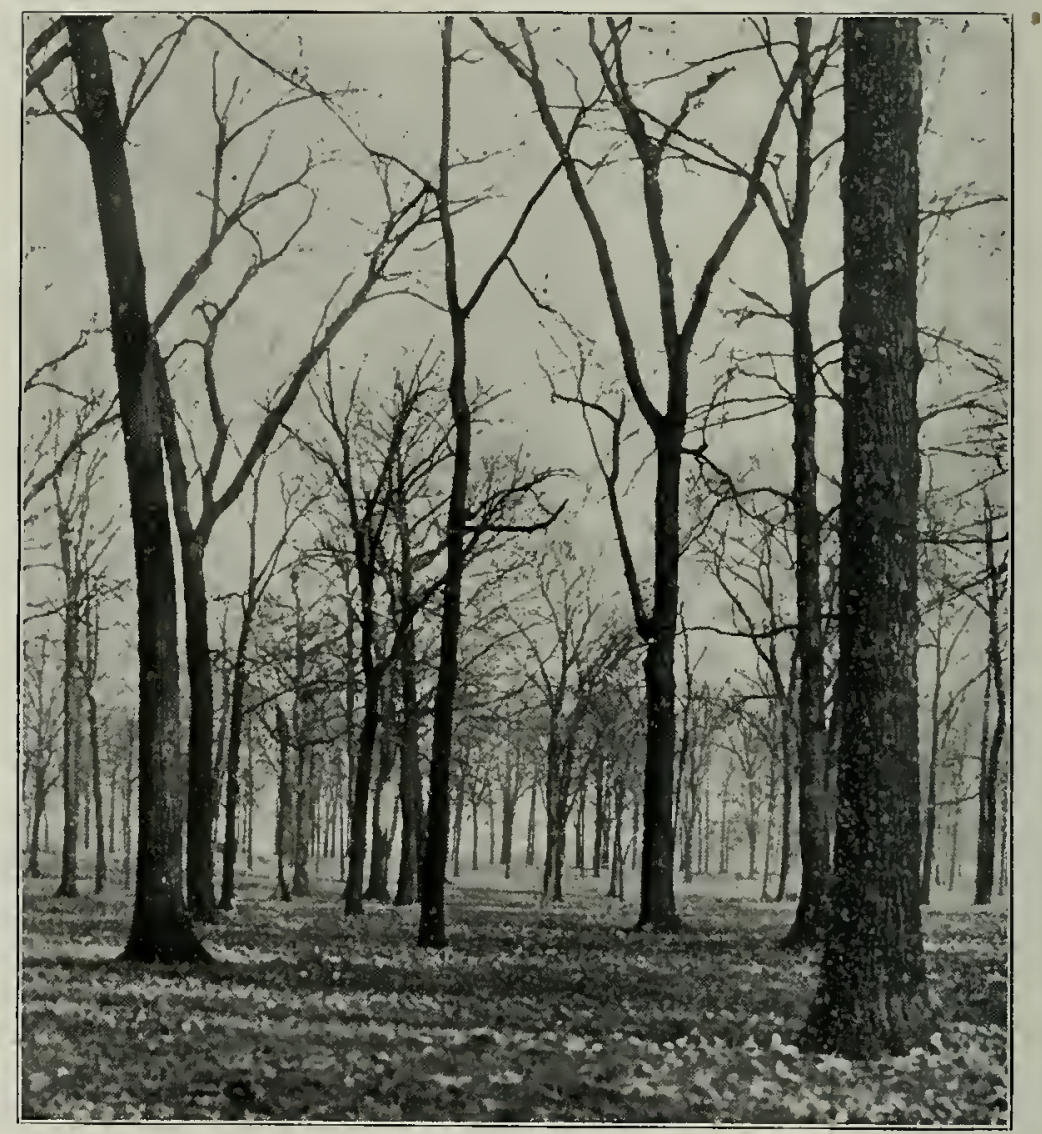

GRALED WOODLOT.

Young trees cleaned out, ground covered with turf. Natural replacement impossible. 


\section{WOODLOT PROTECTION}

The method of establishing and of harvesting a stand usually differ in even-aged and all-aged forests, but the same degree of protection must be given to each against grazing, fire, and attachs of insects and diseases.

Grasing. The injury done to the Hllinois woollots by using them for pisture is greater than injury from all other sotnces. Throughout central and northem Hlinois, woodland is not only being injured; it is being converted to cleared land by grazing.

To appreciate the damage resulting from grazing. We must understand that grasses and trees are conthicting kinds of regetation. A very slight agency in this region is able to upset the balance between them and determine whether a fores or a sol shall hold the contested site. The forest's defenses against grass consist in shade and in a leat mulch completely covering the earth. This blanket of leaves and party-decayed vegetable matter serves the very vital purpose of readily absorbing mointure and checking evaponation : in adclition. it serves to cultivate and fertilize the ground, as it supports bacteria which are the agents for chenical reactions of the greatest importance in building up the soil fertility. The first effect of grazing is the injury to the small trees. I grazed woodlot is strikingly free from underbrush. Hore smlight reaches the ground, and sunlight is as effective as fire in destroying the leaf mulch. Its destruction, compled with the increa-ed sunlight striking the forest floor, pares the way for the occulyation of the site by grasses: and the formation of a sod, in ardition to effectively preventing tree seedlings from becoming established, uses up the moisture. The effect of the very variable moisture conditions which result from the destruction of the mulch of humus and the compacting of the soil by the trampling of stock, is shown as the larger trees begin to die at the top and eventually drop out. First. the grazed woodlot becomes clear of underhrush, then grasses appear and a sod forms, the tops of the large trees die, eventually these trees drop out, and the area is cleared. If you wish to retain any area woorled, you must keep, out live-stock. Grazing and wood production can not be practiced on the same area except to the material disadvantage of each and the lessening of total returns received from the area.

Firc. It is minersally understond that fire is very destructive to ou forests. The ordinary iarm woodlot in lllinois is relatively small. usually isolated from extensive woolland, and can readily be protected by the owner. The reasons why fire protection is imperative are much the same as those given under grazing. The smaller trees are tisully killed outright. and the larger trees suffer wounds which offer ingress to rot fungi, but the greatest injury comes in the destruction of the jeai mulch. A single buming may destroy the accretion of years, and repeated burnings, like grazing, result in the formation of a sod. 
Insects and fungous discascs. The application of insecticides and fungicides and other measures feasible for the protection of valued ornamental and fruit trees are not ordinarily practicable in the woodlot. If a disease or insect attack takes on the proportions of an epidemic, the woodlot owner as an individual usually can not successfully combat it. Such epidemic conditions occur throughout the country both as disease infections and insect infestations. The attacks of a particular disease or insect are generally limited to a certain tree species or genus; they vary in intensity, and in an extreme form they may affect every tree of the species in the region. Disease epidemics on native chestnut are spreading throughout the range of this species so completely that native chestnut seems sure to disappear from our forests. No successtul method has been found to combat it. In sections of the Northeast, Lake States, and Northwest where the white pine blister rust has caused serious loss, organized protective measures have been adopted. Insect epidemic conditions are also common and often destructive. In the Northeastern States losses through infestations of the brown-tail and gypsy moths have reached millions of dollars; throughout the range of eastern larch, periodic epidemics of the larch sawfly eliminate this species from the forest; in the IVest and South, the devastation of bark beetles destroys immense acreages of pines. In Illinois diseases have not reached such destructive intensity as to eliminate completely any important species. Insect damage, however, has been serjous enough to restrict the use of certain affected species. The black locust borer is so universally destructive that the use of black locust for post production is advisable only under exceptional conditions. Trees of the black oak group are being killed by a flat-headed borer. Ash and cottonwood are dying in large numbers as a result of the attacks of scale and bark-boring insects. Where marked disease and insect injury are present in our woodlots, it is usually a result of poor forest conditions. The remedies lie in practicing forest hygiene and in destroying diseased trees and those which harbor borers. It should be the rule to remove trees as soon as they show evidences of weakness and stagnation. If bark borers are present in a living tree, it should be cut and peeled, and the bark and tops burned.

Identification of diseases and recommendation of remedial measures will be made upon receipt of a specimen by the pathologist of the Natural History Survey, Room 219, Natural History Building, Urbana, and of insects by the entomologist at the same address. 


\section{ADAPTATION OF TREES TO SOIL}

To get the highest production from the woodlot, it is essential not only that the trees shonld be given protection so that they can be carried to harvesting maturity but also that they should be suited to the site and market demands. The average growth rates of different species of trees vary greatly, even when they are growing under similar conditions. Once the choice has been made as to what form the output of the woorlot should take, the woodlot should be managed with the object of favoring those most rapidly growing species which are suitable for the manufacture of these products. Studies of growth rates correlated with soil types made by the Natural History Survey,* show the relative values of the conmoner soil types for tree growth and the relative growth rates of the species commonly found on each soil type.

The best soils for timber production in this region are the bottomland sandy loams, followed by the bottomland heary loams. the upland loams, the sands. and finally the very compact loans or hardpan soils. If we give the least productive-hardpan soils-a rating of 1 , the relative productiveness of the other soils for unmanaged tree growth characteristic of each soil type is in about the following ratio: sands. 1.8: upland loans, 2.3: bottomland clay loams, 2.8; bottomland sandy loams 6.3. The above ratings, representative of unmanaged forests stocked with species whose presence in the stand is the result of natural forces, are probably very conservative for stands under management. In the latter. only the more rapidly growing species will be permitted to grow. The growth rates on the poorer soils are uniformly low, but with improved soil conditions not only do the growth rates increase, but there is also an increased number of the more rapidly growing species from which to choose. The prospects of raising the production on the hardpan soils through management of the woodlot are not encouraging, but on all other soils the managed woodlot is clearly capable of producing nuch better returns than the unmanaged.

Tables II. III. IV, I, VI and VII show the average growth rates on these five general soil groups at 20 -year periods in Illinois. The growth rates are indicated by the diameter inside the bark on the stump, by the height, and by the cubic feet of stem exclusive of bark. In a managed woodlot the growth rates should be more comparable to the even-aged fignres as shown in these tables than to the all-aged figures. 


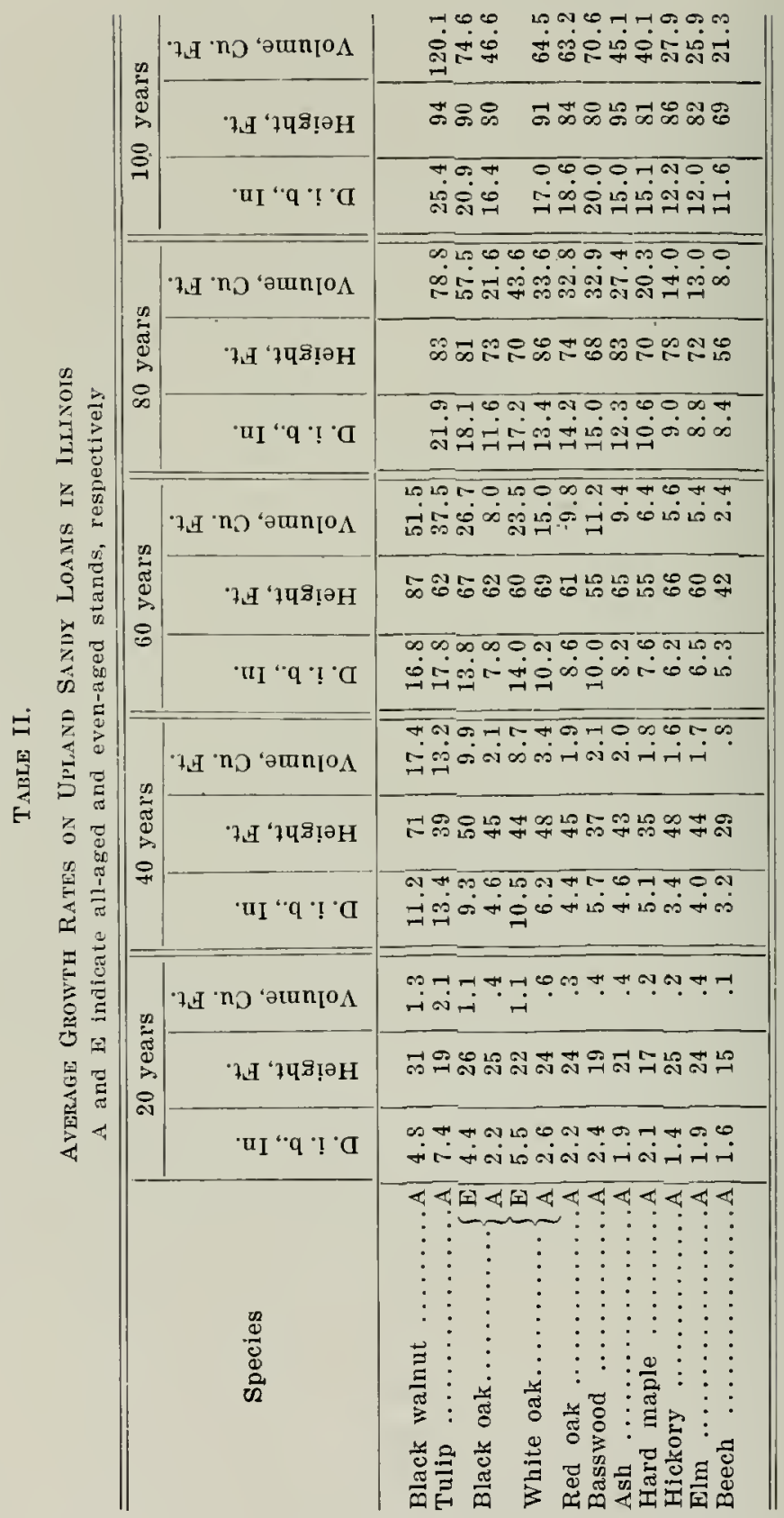




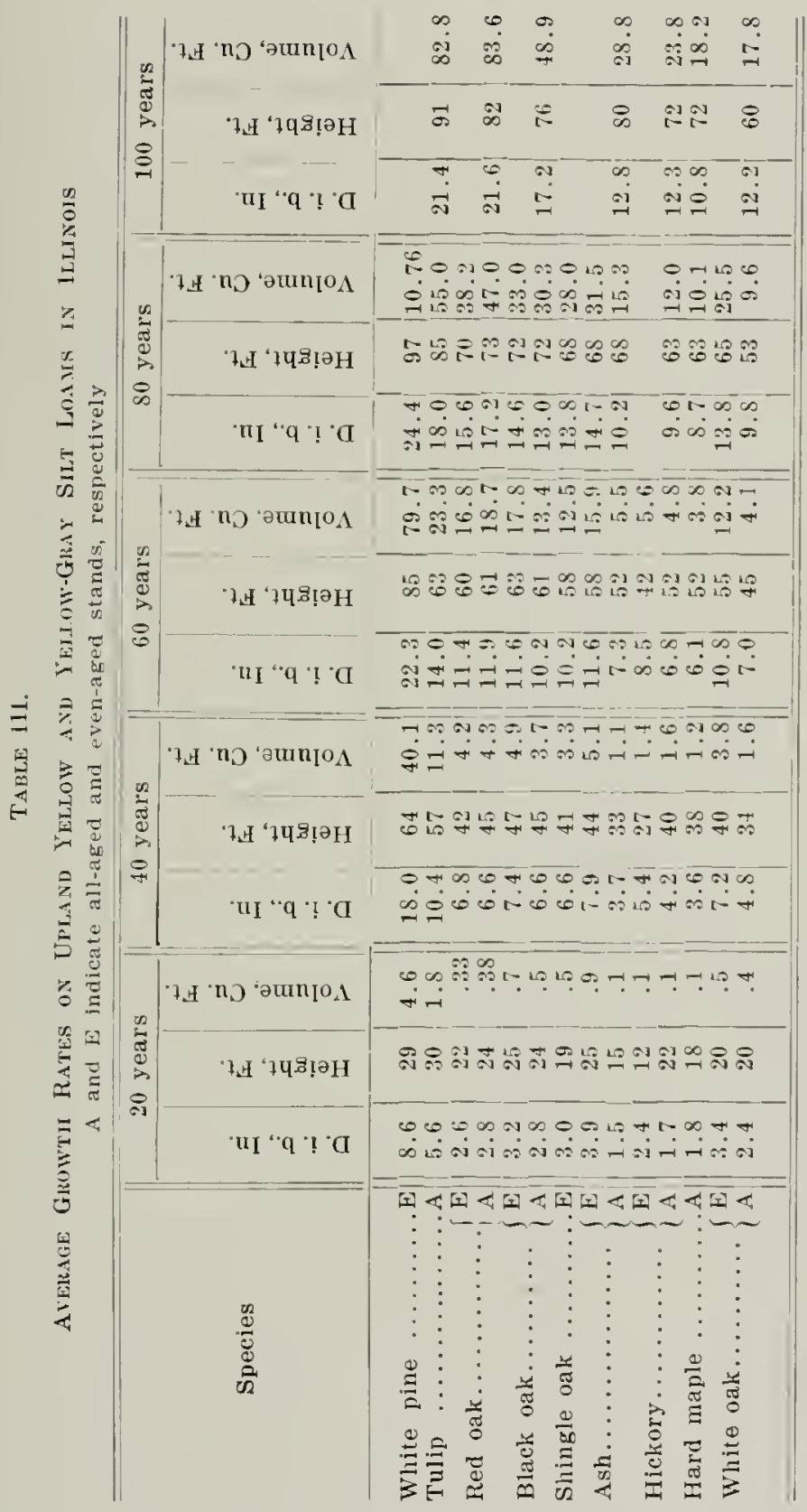




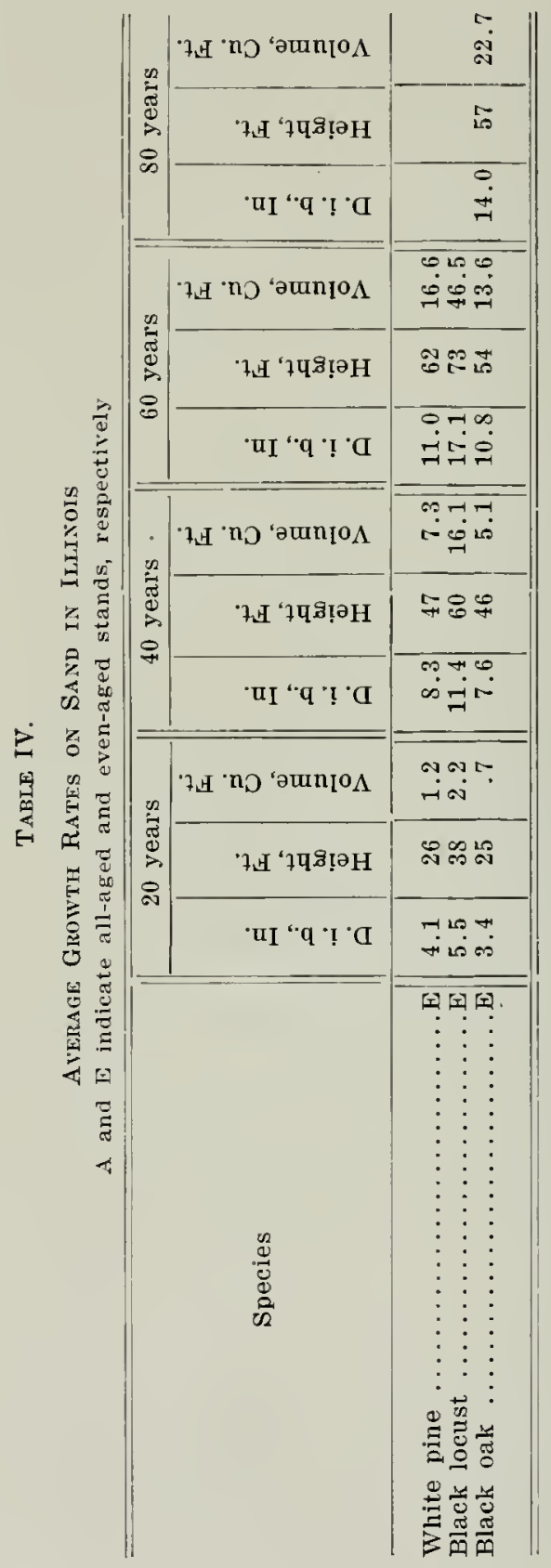




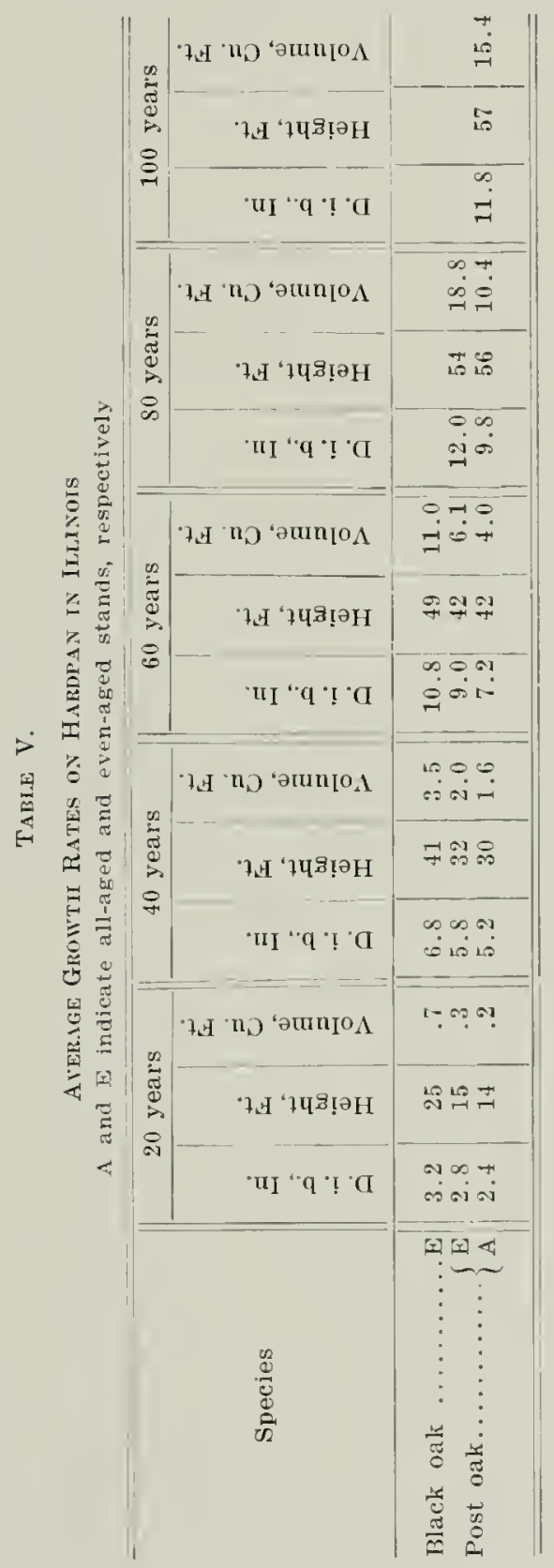




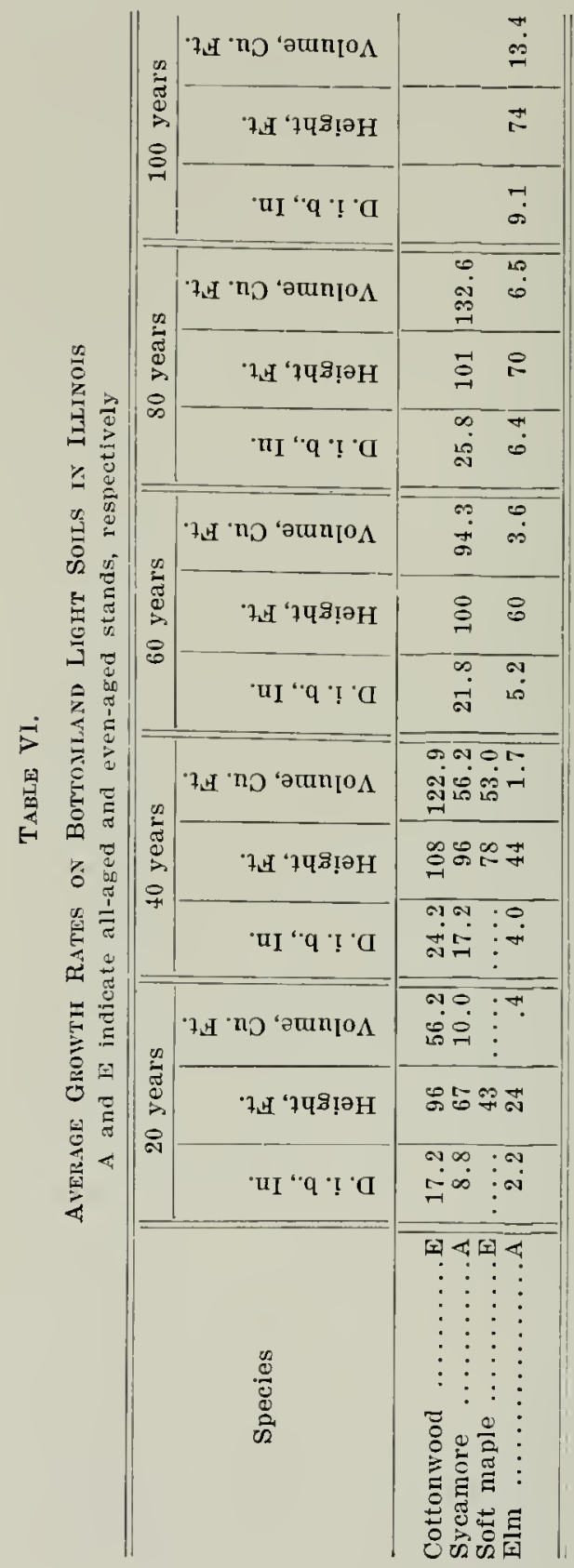


a Manual of Woonlot Mandgemext

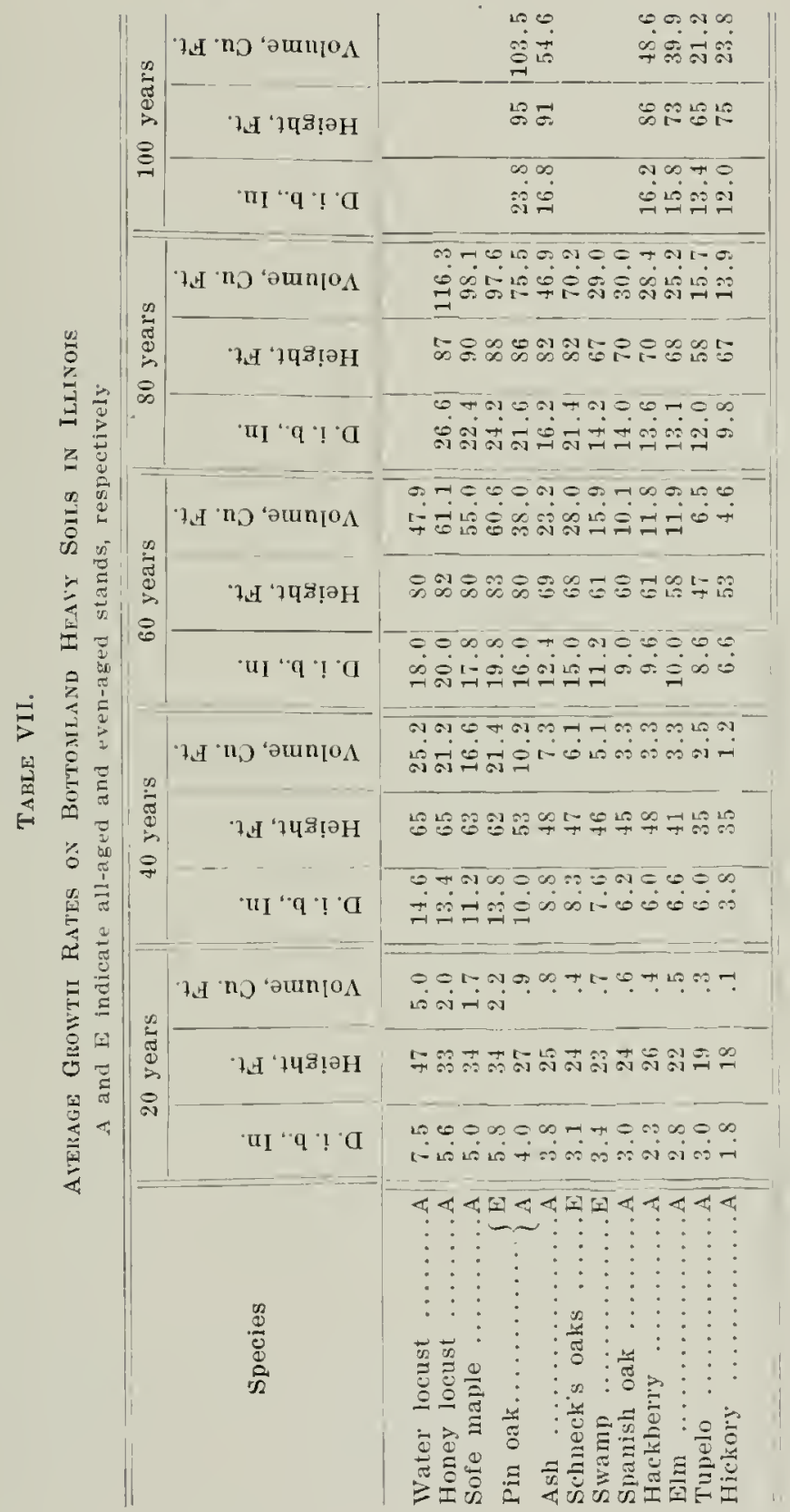


An inspection of these growtl measurements emphasizes the importance of elininating the slow-growing species. The following list contains those slow-growing or otherwise undesirable species which are least suited to a place in the Illinois woodlot.

WEed TREes

Box elder

Hard maple

Buckeye

Shadbush

Pawpaw

Birch

Hickory

Hackberry
Redbud
Dogwood
Persimmon
Beech
Butternut
Red cedar

$\begin{array}{ll}\text { Black gum } & \text { Elm } \\ \text { Hop hornbeam } & \text { Ailanthus } \\ \text { Shortleaf pine } & \text { Jack pine } \\ \text { Aspens } & \text { Crabapple } \\ \text { Scrub oak } & \text { Tupelo gum } \\ \text { Cypress } & \\ \text { Arbor vitae } & \end{array}$

Table VIII is a compilation of those species which are recommended because they have high growth rates and have the mechanical properties necessary for the production of the given product. The fastest growing species are listed first.

TABLE VIII

List of Species Reconalexpen for Specific Soll Conditions and Products

\begin{tabular}{l|l|l|l|l}
\hline \multicolumn{2}{c}{ FOR BOTtomand } \\
Flooded for long periods & Not flooded for long periods \\
\hline Light Soils & Heavy soils & Heavy soils & Light soils \\
\hline
\end{tabular}

For Production of High-Grade Veneer Logs

\begin{tabular}{l|l|l|l}
$\begin{array}{l}\text { Red Oaks } \\
\text { White oaks }\end{array}$ & $\begin{array}{l}\text { Red oaks } \\
\text { White oaks }\end{array}$ & $\begin{array}{l}\text { Black walnut } \\
\text { Red oaks } \\
\text { White oaks }\end{array}$ & $\begin{array}{l}\text { White oaks } \\
\text { Red oaks }\end{array}$ \\
\hline
\end{tabular}

For Production of Posts

\begin{tabular}{|c|c|c|c|}
\hline $\begin{array}{l}\text { Catalpa } \\
\text { White oaks }\end{array}$ & $\begin{array}{l}\text { Catalpa } \\
\text { White oaks }\end{array}$ & $\begin{array}{l}\text { Catalpa } \\
\text { Mulberry } \\
\text { Black walnut } \\
\text { White oaks } \\
\text { Sassafras }\end{array}$ & $\begin{array}{l}\text { Catalpa } \\
\text { Mulberry } \\
\text { White oaks }\end{array}$ \\
\hline
\end{tabular}


FOR BOTTOMLAND Continued.

Flooded for long periods

Light Soils $\mid$ Heavy soils $\quad$ Light soils $\mid$ Heavy soils

\section{For Production of Piling}

\begin{tabular}{l|l} 
Pin oak & Pin oak \\
Red gum & Red gum \\
Sycamore & Sycamore \\
Red oak & Red oak \\
White oak & White oak \\
Black oak & Black oak \\
Shingle oak & Shingle oak \\
Ash & Ash \\
\hline
\end{tabular}

Pin oak
Sycamore
Red oak
White oak
Black oak
Shiugle oak
Ash

Pin oak

Sycamore

Red oak

White oak

Black oak

Shingle oak

Ash

\section{For Production of Ties}

\begin{tabular}{l|l|l|l} 
Sycamore & Sycamore & Sycamore & Sycamore \\
Ky. Coffee tree & Ky. Coffee tree & Black walnut & Ky. Coffee tree \\
Honey locust & Honey locust & liy. Coffee tree & Honey locust \\
Pin oak & Pin oak & Honey locust & Pin oak \\
Red oak & Red oak & Pin oak & Red oak \\
White oaks & White oaks & Red oak & White oak \\
Black oak & Black oak & White oak & Black oak \\
Shingle oak & Shingle oak & Black oak & Shingle oak \\
Ash & Ash & Sassafras & Sassafras \\
& & Shingle oak & Mulberry \\
& & Mlulberry & Ash
\end{tabular}

\section{For Production of Lumber}

Cottonwood

Water locust

Sycamore

Soft maple

Ky. Coffee tree

Honey locust

Red Gum

Pin oak

Red oak

White oak

Black oak

Ash

Shingle oak
Water locust

Sycamore

Soft maple

Coffee tree

Honey locust

Red gum

Pin oak

Red oak

White oak

Black oak

Ash

Shingle oak
Cottonwood

Sycamore

Black walnut

Soft maple

Coffee tree

Honey locust

Tulip

Pin oak

Red oak

White oak

Basswood

Black oak

Ash

Shingle oak
Sycamore

Soft maple

Coffee tree

Honey Jocust

Pin oak

Red oak

White oak

Black oak

Ash

Shingle oak 
FOR BOTTOMLAND-Concluded.

\begin{tabular}{l|l|l|l|l}
\multicolumn{2}{c}{ Flooded for long periods } & Not flooded for long periods \\
\hline Light Soils & Heavy soils & Light soils & Heavy soils
\end{tabular}

\section{For Production of Mine Timbers}

\begin{tabular}{l|l|l} 
Sycamore & $\begin{array}{l}\text { Sycamore } \\
\text { Coffee tree }\end{array}$ & Sycamore \\
Catalpa & Catalpa & Coffee tree \\
Honey locust & Honey locust & Honey locust \\
Red gum & Red gum & Red gum \\
Pin oak & Pin oak & Black walnut \\
Red oak & Red oak & Pin oak \\
Black oak & Black oak & Red oak \\
White oaks & White oaks & Mulberry \\
Shingle oak & Shingle oak & Black oak \\
Ash & Ash & White oak \\
& & Shingle oak \\
& & Ash
\end{tabular}

Sycamore Coffee tree Catalpa Honey locust Red gum Pin oak Red oak Black oak White oak Shingle oak Ash

\section{For Production of Slack Cooperage and Average Veneer Logs}

\section{Cottonwood}

Sycamore

Water locust

Soft maple

Coffee tree

Honey locust

Red gum

Willow

Ash

Sycamore
Water locust
Soft maple
Red gum
Honey locust
Coffee tree
Ash

Water locust

Soft maple

Red gum

oney locust

Coffee tree

Cottonwood
Sycamore
Soft maple
Coffee tree
Honey locust
Willow
Tulip
Basswood
Ash

Cottonwood

Soft maple

Coffee tree

Cocust

Basswood

$\mathrm{Ash}$
Cottonwood

Sycamore

Water locust

Soft maple

Coffee tree

Honey locust

Red gum

Pin oak

Red oak

Willow

White oak

Black oak

Ash

Shingle oak

\section{For Production of Cordwood}

\begin{tabular}{l|l} 
Sycamore & Cottonwood \\
Water locust & Sycamore \\
Soft maple & Soft maple \\
Coffee tree & Coffee tree \\
Honey locust & Honey locust \\
Red gum & Black walnut \\
Pin oak & Pin oak \\
Red oak & Red oak \\
White oak & Willow \\
Black oak & Tulip \\
Ash & Magnolia \\
Shingle oak & Basswood \\
& Black oak \\
& White oak \\
& Shingle oak \\
& Ash
\end{tabular}

Sycamore

Soft maple

Coffee tree

Honey locust

Ash 
TABIE VIII-(Continued)

List of Siecies Recomarexdel for Specific Soll Coxmtoxs axd Prodects

FOR UPIAND

Sandy Loams $\mid$ Silt Loams I Sand

\section{For Production of High-Grade Veneer Logs}

Black walnut Black cherry

Red oaks

White oaks
Black walnut

Red oaks

White oaks

Black cherry

For Production of Posts

\begin{tabular}{l|l|l|l} 
Catalpa & Catalpa & Passafras & \\
Mulberry & Mlulberry & Black locust & \\
Black walnut & Black walnut & Osage orange & \\
White oaks & White oaks & & \\
Sassafras & Sassafras & & \\
Black locust & Black locust & &
\end{tabular}

\section{For Production of Piling}

White oak

White oak

\section{For Production of Ties}

Black walnut

$\mathrm{Ky}$. Coffee tree

Honey locust

Cherry

Red oak

Black oak

Shingle oak

White oak

Sassafras

Mulberry

Black locust

Ash

White pine Black walnut

Tulip

Mlagnolia

Black cherry

Coffee tree

Honey locust

Red oak

White oaks

Black oaks

Basswood

Ash

Slingle oak

\begin{tabular}{l|l} 
Black walnut & Red oak \\
Ky. Coffee tree & Black oak \\
Honey locust & Black locust \\
Cherry & \\
Red oak & \\
Black oak & \\
Shingle oak & \\
White oak & \\
Sassafras & \\
Nlulberry & \\
Black locust & \\
Ash &
\end{tabular}

For Production of Lumber

White pine Black waluut

Tulip

White pine

Magnolia

Black cherry

Coffee tree

Honey locust

Red oak

White oaks

Black oaks

Basswood

Ash

Shingle oak

\section{Red oak}

Black oak 
FOR UPIAND-Concluded.

\begin{tabular}{l|l|l|l}
\hline Sandy Loams & Silt Loams & Sand & Hardpan \\
\hline
\end{tabular}

For Production of Mine Timbers

\begin{tabular}{l|l|l|l} 
Black walnut & Black walnut & Red oak & Red oak \\
Coffee tree & Coffee tree & Black oak & Black oak \\
Honey locust & Honey locust & Sassafras & Post oak \\
Catalpa & Catalpa & \\
Sassafras & Sassafras & & \\
Red oak & Red oak & & \\
Black oak & Black oak & & \\
White oaks & White oaks & & \\
Mulberry & Mulberry & \\
Ash & Ash & \\
Black locust & Black locust &
\end{tabular}

For Production of Slack Cooperage and Average Veneer Logs

\begin{tabular}{l|l} 
Coffee tree & Coffee tree \\
Honey locust & Honey locust \\
Tulip & Tulip \\
Magnolia & Magnolia \\
Basswood & Basswood \\
Ash & Ash \\
\hline
\end{tabular}

For Production of Cordwood

Black walnut Coffee tree Honey locust Tulip

Magnolia

Black cherry

Sassafras

Red oak

Black oak White oak Mulberry Basswood Ash Black locust

\begin{tabular}{l|l} 
Black walnut & Sassafras \\
Coffee tree & Red oak \\
Honey locust & Black oak \\
Tulip & Black locust \\
Magnolia & \\
Black cherry & \\
Sassafras & \\
Red oak & \\
Black oak & \\
White oak & \\
Mulberry & \\
Basswood & \\
Ash & \\
Black locust &
\end{tabular}

Red oak Black oak

Post oak 


\section{EVEN-AGED SYSTEM OF SILVICULTURE}

A silvicultural system is a broad plan of managenent under which a forest is reproduced and developed. The two general types of forests which can be dereloped are eren-aged and all-aged. Even-aged torests contain trees of approximately uniform size, all of which reach harresting maturity and are cut at approximately the same period: all-aged forests, as the name implies. contain trees of rarying ages and sizes. No system based upon the idea of clear cutting is well suited to our Illinois woodlots. One important function of the woodlot is to supply the farm requirements for certain wood products. A clear-cutting system results in the formation of an even-aged stand, incapable of vielding any products until it has passed through the sapling stage. The returns irom the even-aged stands are periodic, and the interval between periods of returns is so long that the interest compounded on the maintenance costs protection, taxes, cleanings-may completely absorb all proceeds. To illustrate the influence of compound interest where returns are deferred: if taxes of $\$ 0.50$ per acre per year are paid for 30 vears $w$ hile the stand is going through the sapling stage. the actual outlay for taxes totals $\$ 1.5$, but the interest on these payments compounded at the rate of 5 per cent totals \$18.4t. On the arerage upland soils, at least 60 vears are required to produce hardwood trees large enough for ties or small sawlogs. At $\$ 0.50$ a year. the total outlay for taxes is $\$ 30$ per acre, but the interest on this amount, when compounded over this period at jo per cent totals $\$ 146.29$. On this basis of calculation, only trees of exceptionally rapid growth and high value can show a profit when grown in even-aged stands. A discussion of the eren-aged srstem follows.

Even-aged woodlots are common throughout central and northern Illinois. The economic conditions by virtue of which such stands originated and dereloped are rapidy altering and should force the complete clearing of these stands on the high-grade agricultural land and should lead to their alteration to all-aged stands on the true forest lands. During the three decades prior to rail transportation when the tide of immigrants settled the prairies. there was a tremendous drain upon the local forests. amounting almost to clear cutting. The plow at the same time stopped the sweep of destructive fires, and the removal of the old forest and the cessation of fire was closely followed by the natural reestablishment of young trees. With the advent of the railroad. these young trees were permitted to grow. since construction materials and fuel requirements were supplied irom other regions. Pressure for cleared land has subsequently resulted in clearing arable areas occupied by this second growth. thus incidentally supplying the farm with certain wood products, but very little cutting has been done in the stands which remain. The majority of these even-aged stands grow on upland sites and are between 60 and 90 vears in age, and the diameters fall between $s$ and 18 inches. 


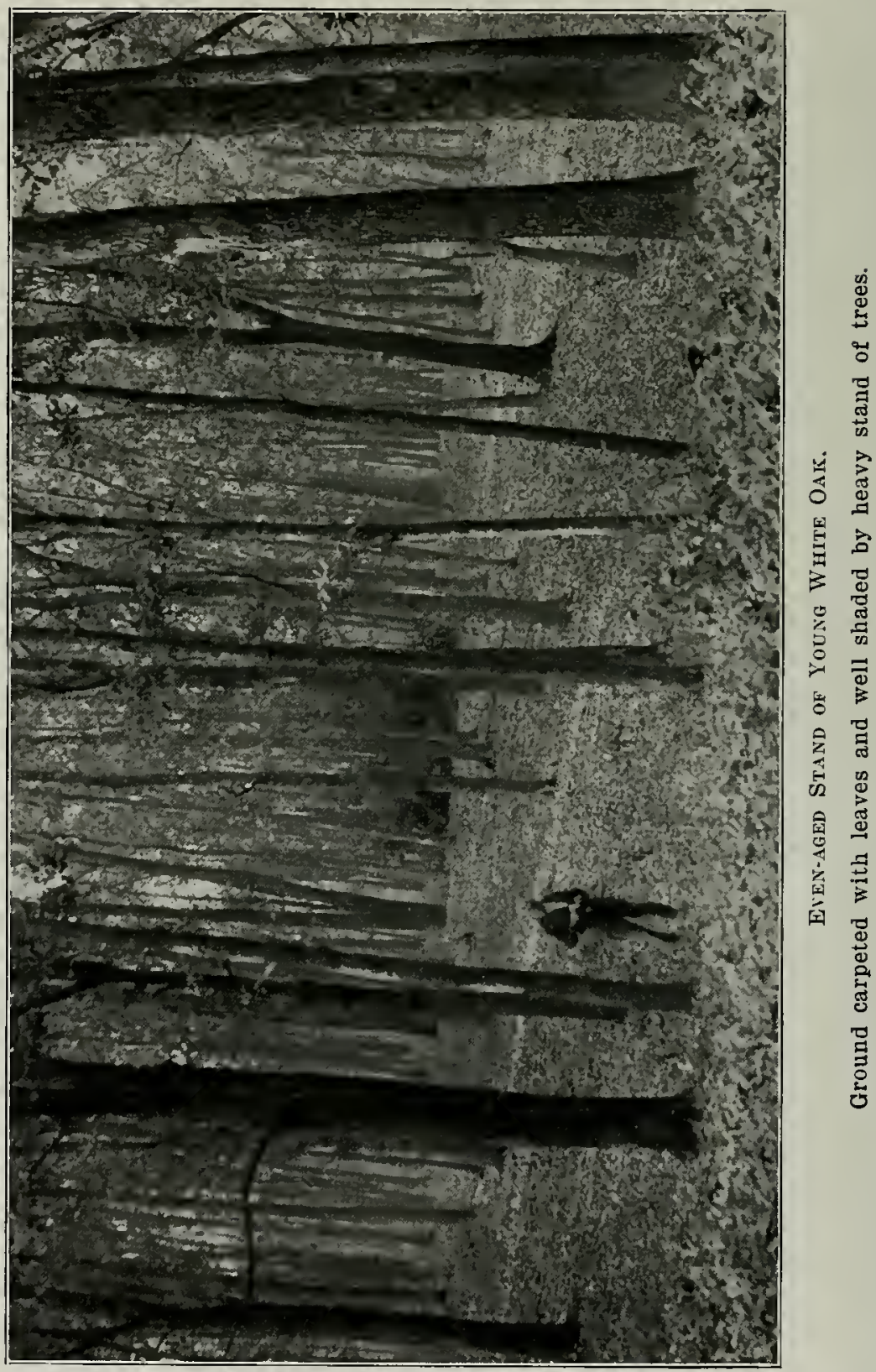


As the timber famine becomes more acute, the farmer will draw upon these woodlots for his requirements, gradually changing them to allaged woodlots. But since the even-aged type usually follows clear cutting or the natural and planted reforestation of abandloned fields, there will always be stands of this character.

The practice of growing wood crops in even-aged stands is more applicable to bottomland than to tpland regions. On the bottomlands subject to inundation, natural regeneration after a clear cutting is a certainty, although it is very difficult to control the kinds which seed in, because the floodwaters deposit seeds from outsile sources and carry away seed from local sources. I'lant growth on such bottomlands is usually rank-weeds, vines, and worthless trees are very aggressive-and under an all-aged, or selection, system constant work is necessary to prevent the useless species from suppressing the useful. The unbroken canopy of the even-aged stand offers less farorable conditions for climbing vines. Certain useful bottomland species have very rapicl growth rates: yet these trees are often intolerant of shade, developing better in even-aged stands. Finally, tall straight stems suitable for piling can best be developed in even-aged bottomland stands. Under these conditions it may be expedient to use an eren-aged system.

The management of even-aged stands is less complex in many respects than that of all-aged stands. The process may be clivided into (1) development of the crop, (2) harvesting, and (B) reestablishing of a new crop. The proper development of the crop is attained through protecting the area so that an abundance of trees may grow and through the juclicious use of the axe so that the maximum growth may be concentrated on the trees which are carried to the final harvest. The natural reestablishment of a new crop can usually be sccured by observing a few rules at the tine of harvesting the old crop.

\section{DeVELOMANT OF AN EVEN-AGEJ STAND}

The stand on the well-stocked acre starts with several thousand snall trees. In a few years these lecome a thicket of saplings. The struggle for light at this stage is very intense, as each tree races upward in the effort to overtop its neighbor. When the polewood stage is reached, there are approximately to0 trees per acre, ranging in diancer from 2 to 10 inches. The increasing height brings adiled difficulty in transporting supplies from root to crown, and the height growth slows down. It this stage, trees must have room to expand laterally in order to make the best growth; hence, thinnings should he macle. This is the opportunity to insure the representation of desirable trees in the final crop by cutting into the following classes: (1) undesirable species (see p. 118). and (2) trees of desirable species but poor form. The forest tree should be tall and straight with a relatively short crown and a long stem. The thriftier trees of the desirable species which should be carried to maturity 
are less than half the number present, but the rule should be to thin lightly, cutting only those trees which are directly interfering with the development of the select trees. In general, not more than a quarter of the trees should be taken out in any thinning, and the crowns of the trees left should close the canopy in 5 or 6 years. All material which can not be utilized should be left on the ground to decay. It should not be burned except in the emergency of insect or disease attacks. When it is evident that the trees are again suffering from crowding, other thinnings should be made. The average numbers of trees per acre on unmanaged even-aged stands at different decades are shown in Table IX.

The heavy mulch of leaves and humus, a characteristic of good forest conditions, can not be maintained if excessive thinnings occur. The appearance of grass and weeds in abundance after a thinning is evidence that it was excessive. Even-aged stands are often free from an understory of bushes and shrubs, and if not, the owner considers it good practice to clear them out. Such an understory should not be cleaned out. It protects the forest floor by its shade and retards the movements of drying air. Indeed, it is advisable to provide a thicket of bushes along the southern and western borders of the woodlot exposed to dry winds prevailing from these points.

\section{Harvesting the Crop}

Under the even-aged system a stand may be harvested in a single operation or by a series of cuttings. Such cuttings should not be extended over too long an interval-more than 20 years-since young trees usually appear after each cutting and the succeeding stand loses its evenaged character.

\section{ReEstablishment}

Following the removal of an even-aged stand, the area may be restocked by sprouts or seedlings or both, or restocking may fail completely ; therefore, a knowledge of conditions favorable to regeneration is essential to intelligent management.

\section{REGENERATION FROM SPROUTS}

Common Illinois hardwoods show a capacity to send out sprouts when trees are cut under certain conditions. These sprouts grow rapidly for several years, but trees developing from then do not eventually attain the dimensions of trees grown from seedlings, and rot commonly enters the sprout through the decay of the stump to which it is attached. The/sprouting capacity weakens and is lost as the tree matures. For these reasons, stands of sprout origin are not well suited to the development of trees for the larger logs, nor can stands be renewed through sprouts from these larger stumps.

This method of regeneration is, however, silviculturally suited to stands handled on a short rotation for the production of posts, cordwood, and mine timbers. The trees should be cut during the dormant season; 
TABLE IX. ATERAge YELDS FROM EvEX-AgeI STANDS IX IllixoIs

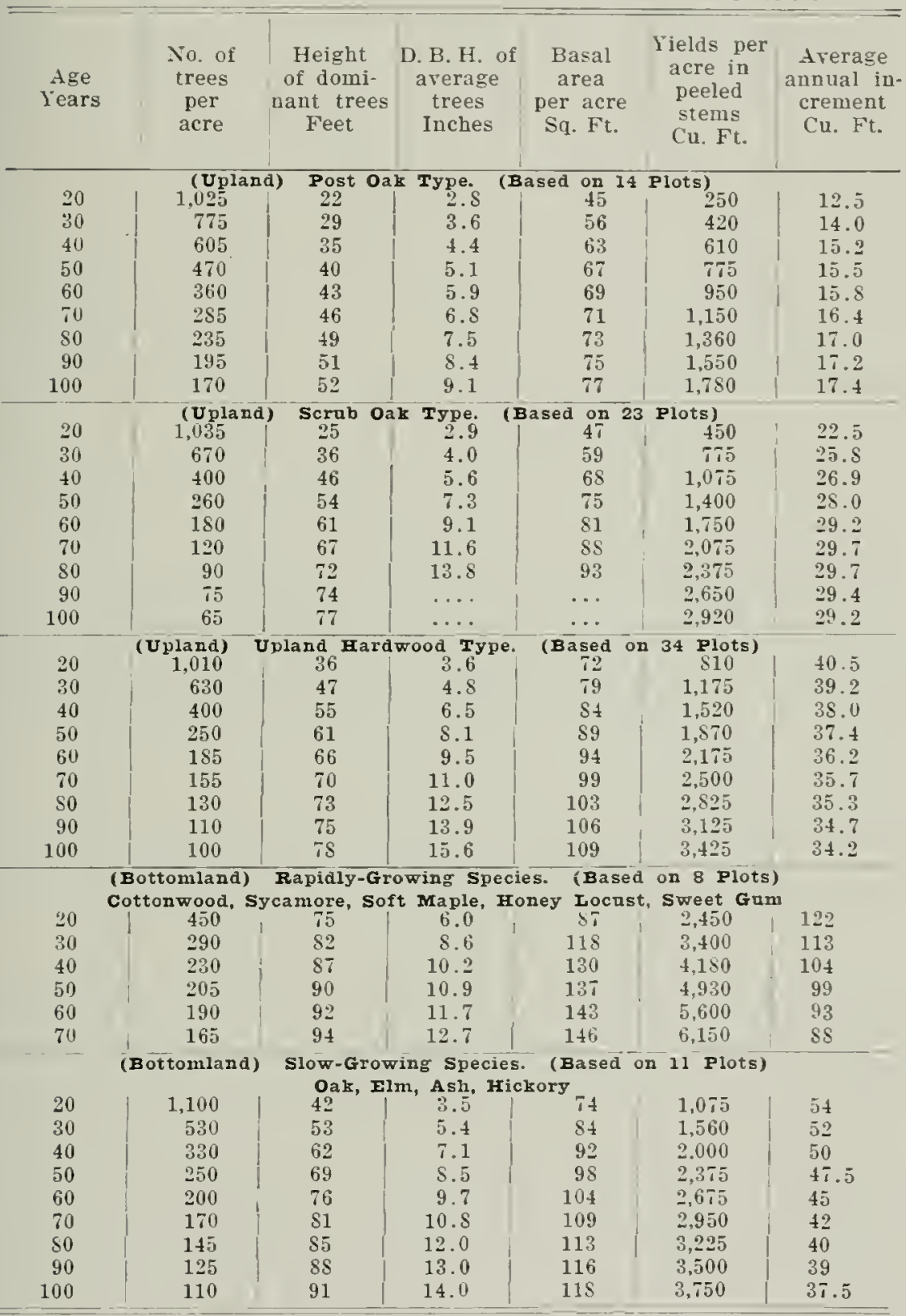


the stumps should be low, and it is preferable to cut the top of the stump on a slant to allow water to drain off. Trees cut during the growing season exhibit a weakened sprouting capacity, and the sprouts are frequently killed by the autumn frosts before the tender tissues harden. Sprouts from low stumps are usually more vigorous, and conditions are less favorable to the decay of stems than in trees growing from high stumps. The sprouting capacity varies for different species, but, in general, stumps should not be more than a foot in diameter for good results. It usually happens that too many sprouts develop and a thinning becomes necessary. This should be made in the early sapling stage when the crowns are closing and crowding each other. The object is to leave plenty of thrifty stems to form the stand but to cut out the less desirable ones which are crowding the others. Frequently the thinning is cheapened by lopping off the tops of undesirables with a nuchéte or a bush hook sufficiently to check them and permit the desirables to get above them.

\section{REGENERATION FROM SEED}

In case the stand is carried past the period of vigorous sproutingabout 60 years for most species-, provision shonld be made for seedling reproduction or for replanting. The two different methods of securing natural seedling regeneration are as follows:

1. When the old crop is removed in a single cutting, the operation should take place after the trees have matured a heavy seed crop. Since heavy seed years vary somewhat for different species, best results are attained by selecting the species which is sufficiently well represented to insure the proper amount of seed production and which is the most desirable tree to grow, and then by clear cutting the area immediately after this species has matured a heavy seed crop. The layer of leaves which covers the ground under normal forest conditions is very favorable to the establishment of heavy-seeded trees, such as the oaks and uther nut trees; it is unfavorable to the secding in of elm, ash, tulip, and otler lightseeded trees. In logging the area, the ground will be torn up somewhat, making spots favorable for the establishment of seedlings. The device of burning this leaf carpet will secure excellent results for light-seeded species if a favorable seed year is followed by a moist growing season; but this combination can not be assured. Therefore, as a failure to reestablish the forest under natural seeding is irrevocable after the seed trees have been cut, a burning is not recommended.

2. In order to positively insure the satisfactory restocking from the trees of the crop to be harvested, the stand can be harvested in two operations. The first cutting removes about 40 per cent of the total number of trees and, by opening up the stand, creates light and heat conditions favorable to the establishment of seedlings. The trees removed in this first cutting are those of undesirable species or form; the 60 per cent left should give character to the succeeding stand. When seedlings appear abundantly in the openings, these remaining trees are removed. Since 
all seed trees are not cut until seedlings are established, this is the safest method of securing seedling regeneration from an even-aged stand. Under this system in light burning previous to the falling of the seed crop is justified where the leaf litter is heav and where it is desired in secure seedlings from light-seecled species.

\section{APILICATION OF TIIF EVEN-AGED SYSTEM \\ Specics sutable for production of piling}

Temporary piling includes any sombl timber that will stand driving. such as a-h, leech. lirch, cherry, sap cypress, sap white oak, red oaks, maple, black gum, and sycamore. In the application of the erenaged system to the production of piling, the object is to grow tall straight trees. Trees of this form can lest lie produced on fertile bottomland sites. Red gum, pin oak, and syeanore, especially in youth, develop a long narrow crown, and the main stem continues in the top. I great number of trees of this form can be grown per acre; consecuently, for piling production these species rate high.

Planting, or artificial regeneration, is not economically justifiable: hence, dependence must be placed nipon natural regeneration. An abundince of seedlings can be secured on cleared lottonnlands if light and soil conditions are favorable: a full stand is assured on all cleared. unsorlded floodlands, but manally the stand is a mixture of many species. To produce tall straight stems, the trees should erowd each other during the sapling and polewood stage, so that no heary side branches are formed. Thinnings can usually legin when the larger trees of the stand are a fout in (lianeter breast high (1? inches D. B. H.).

Pin oak un fertile bottomlands produces a $30^{\prime}$ to :3.' pile in forty years. and unmanget stands contain as many as 100 trees to the atcre stuitable for piling.

\section{Intolcrant species, complificd by cottona'ood}

Those tree species which are not sharle-enduring are classed as "intolerant". Sycannose and soft maple helong in this class. but the Carolina poplar, or cottonwood, is the outstanding example of a rapidlygrowing intelent tree which shonld be grown in even-agerl stands. Cotonwoul trees make phenomonal gromith on all but the heaviest lottomland soils, the logs find a reatly market at excellent prices at mills specializing in fruit and egg containers, and the cortwood furnishes 50 per cent of the pulpwood grown in Illinois. Cottonwod has been sucessfully grown in plantations by the prairie farmer. has been developed into it profitable conmercial project in South . Imerica, and is leing developed commercially on lllinois bottonnlands. There is no wood crop in lllinois which promises better returns than this species. 
Cottonwood seeds in naturally on bottomlands where the moist mineral soil is exposed to full sunlight. It does not sced in on ground covered with a layer of leaves or a heavy growth of weeds, nor will it survive if planted under the slade of other trees. Pure stands have come in naturally on river bars and similar deposits and on patches of abandoned plowland. The embankments of levees and drainage ditches are quickly marked by a line of cottonwoods. This species grows best on the alluvial sandy-silt loams; it grows well on alluvial sands and loams, but poorly on ill-clrained alluvial clays. Although well able to grow on the floodlands subjected to repeated inundations, cottonwood does not grow in swamps where water stands continually or on the very poorly drained clays otherwise well above water level.

Cottonwood matures an abundant crop of seed practically every year during the latter part of May and the early part of June, but these seeds must find favorable seed-bed conditions immediately, for they begin to lose their vitality within a week and are dead within a month. The pistillate, or seed-producing, flowers are borne on different trees from the staminate flowers. At maturity the pods open and liberate immense quantities of tiny brown seeds. Each seed is provided with a tuft of long silky hairs which enables it to be readily carried long distances by the wind. Ripening at a period when the larger rivers are at flood, the seeds are also transported long distances by water: but floods may also submerge an area past the germinating period of the seed, thus effectually keeping cottonwood out. This, together with the aggressiveness of weeds on open bottomland areas, has led to the practice of planting such areas to cottonwood rather than depending upon a natural seeding. The methods of planting are outlined on pp. $152-154$.

When light and soil conditions have chanced to be just right, cottonwood has come in on bottomland sites in immense numbers; but since it is a tree which requires abundant sunlight throughout its life, only a very few of the most vigorous trees survive the sapling stage; the stand then opens up, and less valuable but more tolerant trees grow as an understory. A bad cutting practice of harvesting all trees above a merchantable diameter has been developed to conform with market conditions. A few years later some of the survivors have reached a merchantable size and are cut. Meanwhile, the shacle has been sufficient to keep out cottonwood seedlings, but insufficient to keep out elm, soft maple, hackberry, and other less valuable trees. This cutting practice should be changed to a single clear cutting followed by a fire which thoroughly cleans off the ground cover in order to create seed bed conditions favorable for another crop of cottonwood. 


\section{SELECTION SYSTEM OF SILVICULTURE}

The system generally best suited to the woodlot is termed the selection system. It consists in harvesting trees singly or in small groups and in regulating the cuttings so as to bring the stand to produce about the same number of mature trees in each cutting period. In the fullystocked woodlot the total amount cut at any time should balance the total amount grown since the previous cutting was made. Lnder intensive management the mature trees are harvested annually: hence. the total amount of woorl per acre removed should equal the annual growth of the acre. The usual practice is to fix a minimum diameter linnit and to cut each rear all trees which attain this linit. carrying on at the same time such cuttings in the lower-dianeter classes as may be necessary to facilitate the growth of the trees to be carried to maturity and to iree the stand from undesirable trees. Under this method the woodlot contains trees of many sizes: thus the diverse reguirements of the farm can at all times lie supplied. Since some trees are harvested annually, the value of these can be balanced against the annual maintenance costs-protection, taxes, cleanings-. and there is no connpoumling of interest over long periods.

\section{Gexeral Culteral Meastres}

Whether the wondlot $1 x$ managed for the prodtiction of the small products, such as cordwood, posts and mine timbers. the intermediate products, such as ties, piling, ordinary sawlogs, or the large products. such as reneer logs, the gencral cultural measures are sinilar. The first concern should be to insure proper conditions for regeneration. This means. first of all. the absulute protection of the area from fire and grazing. Lnder natural forest condlitions. Where firen and live-stock are kept out, the layer of leaves gives place to a rich, moist layer of partlydecayed organic matter. uncker which is the mineral soil. Small seeds to some extent sift through the layer of leaves: the sprouting acorn or 11 ut can push through to the rich himus and finally to the mineral soil. The remoyal of this laver of leares and the exposire of the humus or bare mineral soil is usially highly conducive to the establishment of seedlings, but the leaves should not be removed. becanse satisfactory regeneration can usually be established with the leaves present and because the injury to the soil through the destruction of leares and humus outweighs: all benefits.

Where fires have repeatedly rum through the woodland or cattle have freely grazed, the conditions are yuite different. Instead of a meliow moist soil, there is hard hry surface or, if sufficiont sumlight, a sod. Keeping fire and cattle ont will nutully bring back the forest trees if there is no sod: but, if a sod has formed, more intensive measures are 


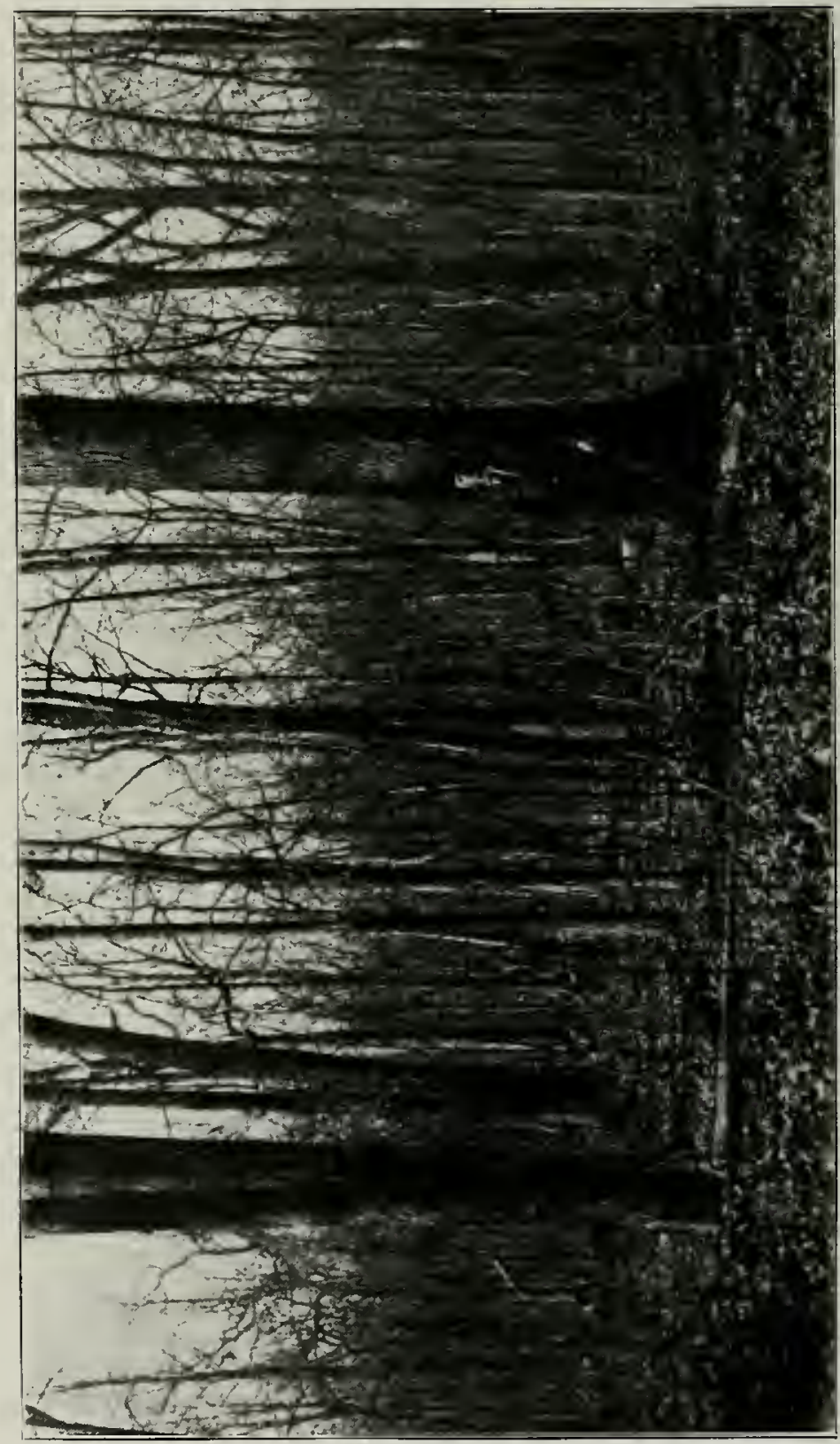

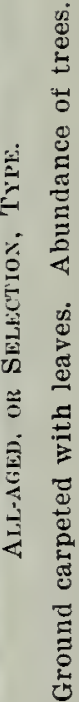


necessary to restore the forest, as germinating seeds can not establish thenselves moler such conditions. Any agency which breaks up the sorl, be it harrow or hogs, is useful: but the best means and often the only sure methorl of securing regeneration is to plant seed or seedlings in spots from which the sod has been removed. Where the woodlot is managed for the production of small products, satisfactory regeneration can be secured largely from sprouts. When managed for the production of medinm and large products, this method can not be depended on. as the latger stumps do not sprout vigorously and the trees which develop from sprouts, although growing rapidly until the polewood stage is reached, do not develop into mature trees as large as those from seedlings.

After the woodlot has been managed under the selection system for a period long enough to secure good forest conditions. abundant natural reproduction is a practical certainty, and management will consist largely in trying to insure the establishment in sufficient numbers of the most desirable species. The rather common practice of marketing the valualsle species from the woodlot without taking any positive steps to reestablish a valuable snccessor has resulted in a two-fold evil. The unmerchantable or low-grade species practically dominate the mature classes and dehige the area with seed. Thus the trees remaining in the woollot have a low value, and these inferior species will perpetuate themselves and make up the succeeding stands. Management aims to correct this condition ly weeding ont the inferior species, thus lessening the seed supply and decreasing their representation in the reproduction, and by securing the establishment of desirable species, even resorting to planting when natural reproduction is not wholly successful.

Since, muder the selection system, the aim is to manage the woodlot so as to bring about the same number of trees to cutting nuaturity each year, the area occupied by each age class should be approximately the same. If the average time required to grow trees suitable for mine timbers, cordwood and posts is 40 years, then each age class would occupy one-fortieth of the area. In actual practice this exact adjustment of age classes can not be attained, becatse of irregularity in regeneration and variation in growth rates, and becanse the amual yields from small areas often are insufficient to justify an annual cut. Athough in theory the area occupied by each age class is the same, the number of trees in each age class is not. On average upland loams there will be something like 42 one-year-ukt trees and but 10 forty-year-old trees on the acre. In the case of such small products as mine timbers, cordwood, and posts requiring 40 years, only 400 out of 1000 trees are brought to maturity. In the case of sawlogs repuiring 80 years, there are 600 trees per acre, 130 of which are carried to maturity. In the case of veneer logs requiring up to 1 in years, only so would be carried to maturity out of a total of 36 trees. Since from 60 to 80 per cent of the total number of trees fail to reach maturity, it is not necessary to have more than hali the reproduction of clesirable species. Thus, for small products, it would be 
considered satisfactory regeneration if 20 trees per acre of a desirable species were established annually; for logs, 4 trees; and for high-grade veneer, one tree of a desirable species per acre properly located will suffice. The young trees of the desirable species should, of course, be located in the openings formed by the removal of the older trees. Frequently, well-located young trees, which have become established before the older trees are removed, provide satisfactory successors to the nuatured trees. Commonly, young trees in abundance will appear in any opening; but if these are wholly of undesirable species or if, as in rare cases, reproduction fails, it is advisable to plant seed or seedlings. Methods of planting seed and young trees are described on pages $138-1+2$.

The establishment of clesirable trees in sufficient numbers is half of silviculture; the other half consists in creating light conditions such that the trees to be carried to maturity will require the shortest time consistent with the production of trees of good form. Openings will always be made in the forest by the removal of mature trees and of other trees of undesirable species, but one of the cardinal principles of cuttings should be to make as few openings as possible where the direct sunlight can reach the forest floor. Although from 60 to 80 per cent of the trees which start will not be carried to maturity, these trees perform the useful service of shading the forest floor and preserving moisture conditions decidedly beneficial to soil enrichment as well as to tree growth: and. in addition, by lateral crowding of the select trees during their immaturity, these others force them to rapid height growth and development into trees of good form. On the other hand, the competition for growing space between all trees is keen, and, if nnaided by thinnings, many of the desirable species will be crowded out by less desirable ones. Hence it is advisable to let all trees grow until such a time that the proper development of the select trees can not continue becanse of lack of crown space. and then to cut the undesirable trees which are competing with the select ones. The number of trees per acre or the regularity of spacing of the trees does not indicate whether the stand should be thinned, but rather the growing space available to the crown is the factor determining the necessity of a thinning. The critical examination is overhead. The rule should be to make light cuttings often rather than to depend upon heavy thinnings at longer intervals. Only through experience can the individual develop the skill and judgment by which he determines when crowding ceases to be a stimulus to height growth and becomes a check to proper development. Unutilized tops of felled trees should not be piled and burned, unless burning nunst be resorted to in order to check insects and fungous diseases. The brush should be scattered to lie close to the ground in order to facilitate decay. In woodlots managed for the production of cordwood, posts, and mine timbers, such thinnings would give products of little value: but in woodlots managed for the production of ties and logs, these thinnings should provide posts, cordwood and mine timbers. 


\section{Fixing TIte DiAMeter Limit}

The diameter of a standing tree is customarily taken outside the bark and at a point $4 \frac{1}{2}$ feet from the ground. This is lnown as the diameter breast high, or D.B.H, and affords a convenient basis of classification. If the stand is kept fully stocked in the maller-dianeter classes, and if the area occupied by each class is approximately the same, then, by fixing a diameter to which the select trees must grow betore they are harvested, equal quantities can be harvested each year, yet the cut is atitomatically balanced by growth.

Not only are there certain products which give higher returns than others, but also the returns per acre, even for a given product, vary with the diameters of the trees harvested. The indivilual tree is numerchantable for a definite period of its immaturity: after it attains merchantable climensions, the value increases rapilly as the tree increases in size. The higher value is clue to the added growtl and to the ligher quality of growth. This increase in value continues as long as the tree remains sound and continues growth. Offsetting this increase in ralue as the inclividual tree gains in size is the fact that fewer large trees can be grown per acre. A refinement of management consists in fixing the diameter limit at the size which gives the greatent returns per acre.

The accurate defining of the correct diameter limit for any given moduct and region requires a linowledge of the average time required to grow a tree to each diameter, the number of trees of any given dianeter which can be grown on an acre, the quantities of the product which are produced jer tree and per acre for each rlimeter class, and, finally. the net value of the product. The problen is further complicated by the constant increase in the value of forest products, an increase which often justifies holding trees beyond the time dictated ly iacturs of nat!ral growth. The local influence of malket conditions, together with the variation in the composition of different stands, permits the application of only very general statements to indivirlual woodlots. It is a iact, however. that the smallest diameter at which a tree hecomes merchantalile almost never corresponds to the diameter at which the tree would give the best returns. It is not wise to cut thrifty trees of the lower-cliameter classes which may be merchantable.

\section{ADVANTAGE OF LARGER DIAMETERS}

The rapid increase in value of the individual tree after it enters the merchantable elass is brought out in stulies of black oak on upland loam in Illinois Such a tree having a D. B. H. of $10^{\prime \prime}$ averages one tie worth $\$ 0.50$; a. $12^{\prime \prime}$ tree averages two ties worth $\$ 1.60$; a $14^{\prime \prime}$ tree, four ties worth $\$ 3.80$; a $16^{\prime \prime}$ tree, four ties worth $\$ 4.90$; an $1 \mathrm{~S}^{\prime \prime}$ tree. five ties worth $\$ 5.70$. It takes 52 years to grow 
the tree producing the $\$ 0.50$ tie, and 103 years for the tree producing the $\$ 5.70$ value. If the 10 -inch tree is cut, the gross annual returns per tree approximate one cent; if the tree is allowed to grow to 18 inches, these returns are approximately $5 \frac{1}{2}$ cents per tree.

No information exists as to the number of trees per acre which can be grown to $10^{\prime \prime}$ D. B. H. in 52 years under the selection system, or to $18^{\prime \prime} \mathrm{D}$. B. H. in 103 years. In the absence of reliable data on the average number of trees per acre of a given diameter which can be matured yearly where the selection system has been practiced, recourse must be had to the data collected from fully-stocked even-aged plots. Table $\mathrm{X}$ gives data for such plots on upland loams in this State, the tabulation being in terms of the average D. B. H. of the stand. The average D. B. H., made up from all trees on the plot, includes trees of several diameters, and the yields assume that all trees which have attained a merchantable diameter will be cut, whereas in the selection system only those trees which reach the diameter limit chosen as the most desirable will be harvested. In order to make the data from even-aged stands directly applicable to a selection cutting, the rather doubtful assumption must be made that the number of trees on the even-aged plot of a given age and average D. B. H. is equal to the number of trees actually brought to this diameter in a selection forest over the same period.

The number of ties which can be harvested from the larger tree until the 15-inch class is reached more than makes up for the decrease in the number of trees per acre. Above this diameter the increase in the number of ties per tree is not enough to off set completely the decrease in the number of trees per acre, and the total tie yield per acre decreases. Converted to gross returns. however, it often happens that the increase in value dne to the higher quality of ties which can be secured from the larger-diameter classes may carry optimum gross returns into a larger-diameter class than that for the maximum number of ties. The interplay of quantities and quality, as measured by gross annual returns per acre for ties shown in column 6, indicates that under average conditions of growth the upland woodlots give the highest gross returns on a 15-inch diameter limit. At this diameter these returns per acre are 1.65 times those when a 10 -inch diameter limit is used.

The same general principle, that it is not profitable to cut the low-diameter classes merely because there happens to be a market for them, holds for other products. Rather limited studies of black walnut on sandy loams in this State indicate that 1.58 trees averaging 14 inches on the stump can be matured per acre annually. Such trees average 50 years in age, and the average annual yield per acre is $63 \mathrm{~B}$. $\mathrm{F}$. of lumber $\operatorname{logs}$ worth $\$ 3.15$ at the mill. If trees are carried until they attain a 26-inch diameter, only .57 trees per acre can be matured annually, and such trees average 140 years in age, but the average annual yield per acre is increased to $214 \mathrm{~B}$. F. of veneer $\operatorname{logs}$ and $16 \mathrm{~B}$. F. of lumber logs, totaling $\$ 23.54$ at the mill. Thus the acre managed on the 26 -inch diameter limit gives a gross return of 7.47 times that from the acre on the 14-inch diameter limit. 
TABLE X.

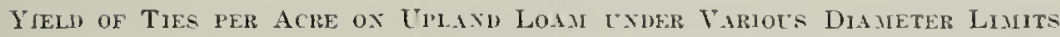

\begin{tabular}{|c|c|c|c|c|c|c|}
\hline $\begin{array}{l}\text { Diameter } \\
\text { Limit } \\
\text { Inches }\end{array}$ & $\begin{array}{l}\text { Height of } \\
\text { Dominant } \\
\text { Tree } \\
\text { Feet }\end{array}$ & Age & $\begin{array}{l}\text { No. of } \\
\text { trees } \\
\text { annually } \\
\text { reaching } \\
\text { diam. } \\
\text { limit } \\
\text { per } A .\end{array}$ & $\begin{array}{c}\text { No. of } \\
\text { ties } \\
\text { annually } \\
\text { harvested } \\
\text { per } A \text {. }\end{array}$ & $\begin{array}{l}\text { Ay. } \\
\text { annual } \\
\text { gross re- } \\
\text { turn per } \\
\text { A. }\end{array}$ & $\begin{array}{l}\text { Ar. } \\
\text { annual } \\
\text { gross re- } \\
\text { turn per } \\
\text { tree }\end{array}$ \\
\hline $\begin{array}{l}10 \\
11 \\
12 \\
13 \\
14 \\
15 \\
16 \\
17 \\
18\end{array}$ & $\begin{array}{l}67 \\
70 \\
72 \\
74 \\
76 \\
77 \\
75 \\
78 \\
74\end{array}$ & $\begin{array}{r}63 \\
70 \\
77 \\
84 \\
91 \\
97 \\
104 \\
111 \\
117\end{array}$ & $\begin{array}{l}2.75 \\
2.21 \\
1.75 \\
1.43 \\
1.21 \\
1.06 \\
0.95 \\
0.86 \\
0.80\end{array}$ & $\begin{array}{r}2.78 \\
3.24 \\
3.64 \\
3.83 \\
3.98 \\
4.02 \\
3.92 \\
3.80 \\
3.73\end{array}$ & $\begin{array}{r}\$ 2.28 \\
2.89 \\
3.29 \\
3.55 \\
3.73 \\
3.76 \\
3.70 \\
3.60 \\
3.50\end{array}$ & $\begin{array}{r}\$ .013 \\
.018 \\
.024 \\
.030 \\
.034 \\
.036 \\
.039 \\
.042 \\
.044\end{array}$ \\
\hline
\end{tabular}




\section{PLANTING TO REENFORCE HARDWOOD STANDS}

$\mathrm{Up}_{\mathrm{p}}$ to this point in the discussion of woodlot management, it has leen assumed that natural reproduction is possible and advantageous, but there are conditions where planting must be resorted to. Tree planting on the farm may be divided into two classes: (1) reenforcement planting within the woodlot, and ( 2 ) planting of cleared areas. The first of these will be discussed here, and the second on pages 143-163.

The principle to be followed in reenforcement planting within the woodlot is to use those species which are not only adjusted to local soil and clinatic conditions but which are also able to compete successfully with the associated native trees and to reproduce naturally under forest conditions. The conifers do not qualify for reenforcenent planting among all-aged hardwoods in Illinois, because those having a sufficiently high rate of growth and value are intolerant of shade and are not well suited to woodlot conditions, nor will they reproduce and hold their place in a hardwood nixtıre. Black walnut, basswood, and red oak are reconmended for woodlot reenforcenent on those soils and sites adapted to these species as shown in Table VIII, p. 118. To these may be added tulip poplar in the southern part of the State.

\section{Black Walnut}

Black walnut is by far the best native hardwood for reenforcement planting. The tree can easily be grown from nuts, the wood is suitable for farm requirements, and the growth rate is relatively rapid. Logs of black walnut connmand a price virtually double that of any other native hardwood, and good markets are accessible. A large percentage of the wahnut now being marketed is conning fron open-grown trees. and the practice is general of leaving seedlings which spring up in vacant places along fences or in pastures. Farm owners liave found that walnut trees set out in plantations on high-grade arable land do not give returns at all comparable to those from ordinary crops, but that trees standing individually or in groups along roads, fences, streams, and hollows, or scattered about in the permanent pasture, are a source of revenue and warrant the slight positive effort necessary to increase their representation in such waste places. A walnut takes up no more room than an elm or hackberry and has a much higher market value.

Black walnut is rather exacting as to soil requirements. It grows best on deep, fertile. well-drained loams with a stable moisture supply. such as are found along the flood-plains of the smaller streams, or in hollows and sheltered coves receiving the wash from adjacent uplands. It makes exceptionally rapid growth on sandy loans. It grows well on the moderately fertile, yellow and yellow-gray, silt loans characteristic of the 
rolling uplands of the timbered regions, and on well-drained, dark, prairie loams. It does not grow on sands or hardpan soils where acidity is high and moisture conditions are variable, nor on swanny areas.

This species is also somewhat exacting as to light requirements. The seedling can persist under an overwood but reruires full overhead light to develop; therefore. in reenforcement planting in a hardwood stand, walnut should be started in openings large enongh to insure such light. This species should be used to supplant other trees which are removed, but there is a limit to the number which should be grown on an acre. It is a space-demanding tree, for the long branches extend almost at right angles to the axis. The canopy is also relatively open, so much so that in pure walnut stands enough light comes through to support grass. It can be grown in groups, but not more than half of the stand should be of walnut if proper forest conditions are retained.

When grown in the open, the tree las a short trunk and wide-spreading crown. A tree developing a long clear bole can be produced by pruning off the lateral branches close to the trunk while the tree is in the sapling stage, or by pinching off the new lateral shoots as they develop luring spring.

\section{Tulip Poplar and Basswood}

Tulip poplar and basswood are not valuable for ordinary farm requirements but are special-purpose woods, and should be grown in those woodlots tributary to a market. Good markets for tulip logs exist in southern Illinois and for basswood logs in both southern and northern Illinois. The natural range of tulip is limited to the southern part of the state, while basswood is of state-wide occurrence. Tulip is slightly more exacting as to soil and light reyuirements, but both species occur on all but extremes of sands and hardpan soils, and each cin naturally establish itself and grow in hardwood mixtures. Tulip must have direct overhead light, being very similar to walnut in this respect. Basswood is rather shade-enduring. and can grow on heavier clays and wetter situations than tulip or walnut. commonly being found on the stream banks as well as on the uplands.

It is not advisable to plant basswood or tulip seel directly in the iroodlot, because the germination of the former is often delayed until the second year and the germination of the latter is meertain. Other less desirable seedlings meanwhile establish themselves. Secds should be planted in a seed bed as described on pp. 141-14\%. The proper time for sowing is in the fall. The proper number of seets per foot of row is shown in Table XI (p. 14\%). In order to produce sturdy stock well able to compete in the woodlot. it is advisable to let the young trees grow two seasons in the seedbed, after which they can be transplanted to the woodlot. 


\section{OAKS}

Red oak, although it is a wood of only medium value for either farm or market purposes, is recommended as a sort of general-purpose tree, because it is one of the most rapidly growing oaks, because it can be easily grown on a wide range of soil conditions, and because its wood has so many uses that markets exist everywhere in the State. It is subject to destruction through the attacks of a flat-headed borer and should not be used in those localities where this insect is killing the black and red oaks. Reenforcement can be made by planting acorns during the spring.

\section{METIIODS OF PLANTING}

The term reenforcement planting has been used for planting done in openings where natural reproduction is not assured. On such blanks, once the desirable species is planted, there is but little danger that reproduction of undesirables will crowd it out. But woodlot improvement cloes not stop with the operation of filling up the blanks with seedlings of valuable species. Such seedlings can be established where an abundance of reproduction of an undesirable kind exists. In this case the un(lesiralule reproduction must be cleaned away from the valuable in order that the latter may properly develop. Such a cleaning should occur at the time when the planting is made and be repeated at any stage of the competition when the unclesirables overtop the planted trees.

When the nut trees and oalis are used, the better method consists in planting the seed where the trees are needed. For basswood, tulip. and other light-seeded trees, the better method is to transplant seedlings where trees are needed.

The acorns of the white oaks germinate in the fall and must be planted at this season: spring is the best time to plant acorns or nuts of the other oaks and nut-bearing trees, as fall-planted seeds are subject to rodent destruction. The seed should be collected in the fall. It is a good plan to place acorns in a vessel of water and discard those which float buoyantly, as this mininizes the number ruined by insects. To store nuts or acorns over winter, place them outdoors in a small heap on a slight elevation where water will not stand, and preferably on well-drained sandy soil. Place a layer of straw or leaves over them and then throw dirt on this, but leave places where the straw ends project out at the side of the mound to insure ventilation. Freezing does not injure them, but as soon as the frost leaves the ground in the spring they must be planted, because acorns especially will quiclily sprout at this time. Most of the black walnuts sprout the first year. but some walnuts will carry over and sprout the second year. In planting. two or three 
nuts are placed in a slight excavation where the tree is to be grown, and about 2 inches of soil packed over them. If squirrels are troublesome, it is advisalule to make several seed spots where ultimately but a single tree may stand, or to jrotect the nuts by covering each one with a tin can frum which the lid has been removed. A crisscross incision in the bottom of the can is made with an axe, the can is placed upside down over the planted nut, and the tree grows thongh the hole punched in the botton. The can rots awy lefore the tree attains a large liameter.

\section{GROWING IIRDWOOD PLANTING STOCK}

Customarily those trees which have small scels are raised in a seedbed during the first year and transplanted to the woodlot as seedlings. Elm, soft maples. willows, and cottonwoods ripen their seeds between April and Jume, and since these seeds are relatively perishilule they shonlel be planted innmediately. The seeds of virtually all other native hardwoods can be planted in the fall. The ideal soil is a well-drained, mellow, sandy-loam, garden soil. It should be tilled until the soil is thoronghly pulverized, then raked level, and the seeds should be sown in rows to a depth two or three times the thickness of the inclividual seed. The rows should be about one foot apart for hand cultivation or three feet if horse cultivation is userl. The object is to sectre a seedling for every four-fifths of an inch of the row, and to do this repuires a knowledge of the germinating capacities of seeds of the species used. see Table XI.

For fall-sowed seed, a mulch consisting of two or three inches of leaves is advisalile, but this should be removed lefore the seeds germinate

TABLE XI.

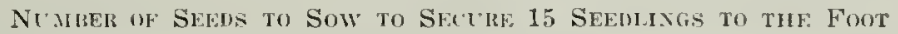

\section{Hardwoods}

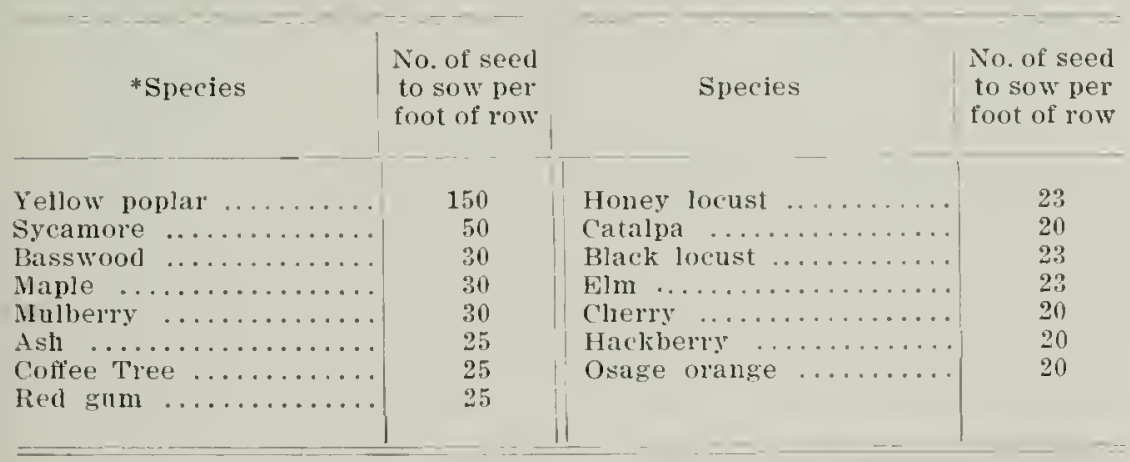

* Based on Table 8, L. S. Dent. Agr. Bulletin 1123. 
in spring. The samc weeding and cultivation should be given as is practiced to insure the success of garden crops. One growing season in the seed bed produces stock of the size most convenient to handle. Stock can be left in the seed bed over winter without mulching. Transplanting should be done in spring as early as possible after the frost is out of the ground. In lifting seedlings from the bed, care nnust be taken to minimize root injury; the trees should never be pulled up but should be turned out by a spade. They should be transplanted immerliately and the roots kept moist while out of ground by covering with wet sacking, moss, or other moisture-retaining matter.

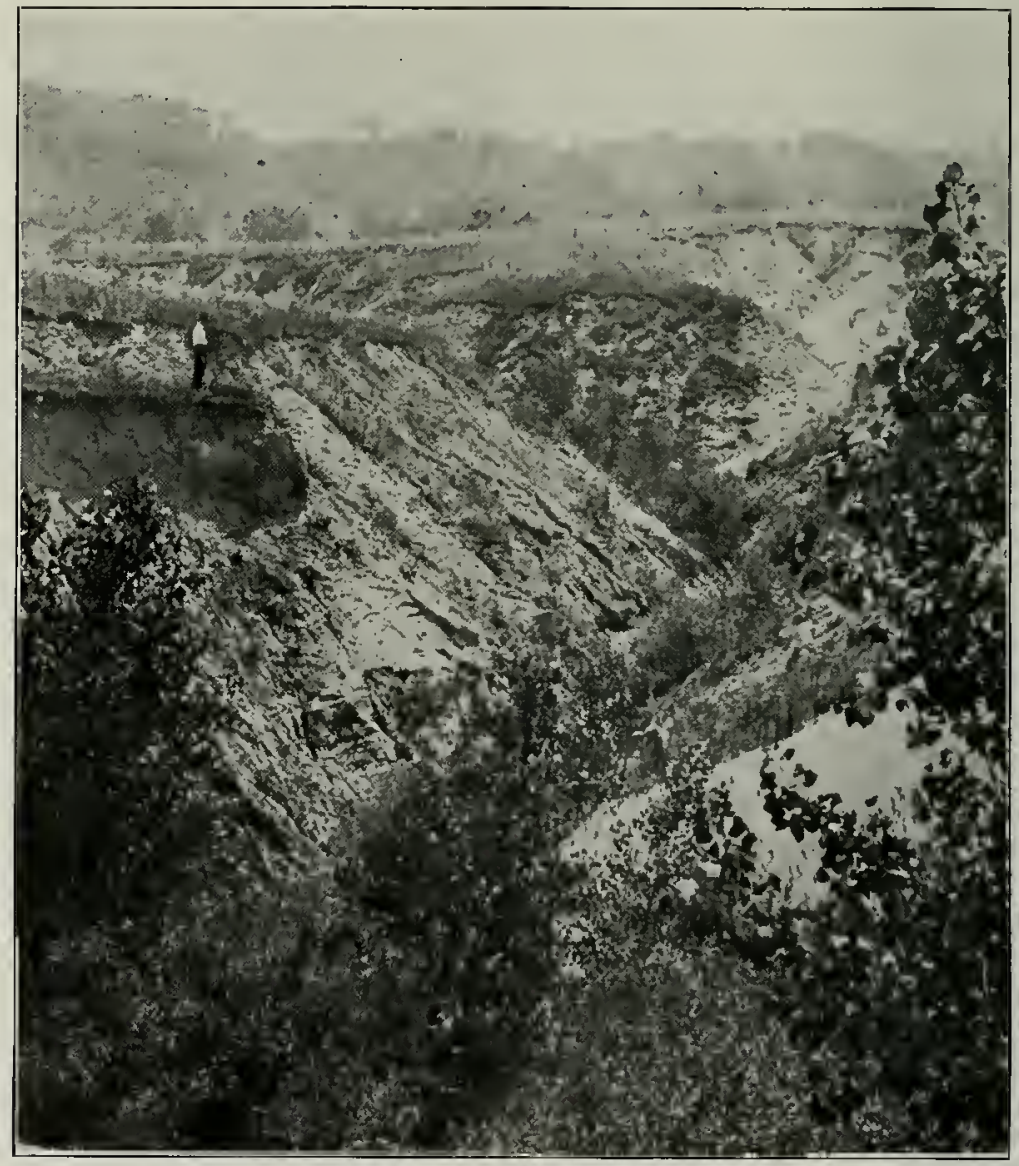

Gullied, Worf-out, Low-grade Solls Should be Planted to Tree Crots. 


\section{PLANTING CLEARED AREAS}

Two disturbing conseguences of forest and land exploitation are forcing a consideration of tree planting on cleared areas. As the forests dinninish, the prices of torest products go up unti] eventually they reach such a height that wood can be growin as a crop at a profit. This is the commercial aspect of reforesting cleared areas. But also, following the development of a region into farm lands, soils from the upland ficlds wash and are leposited over the choice bottomlands, or sands are blown over adjacent fields, so that the protective aspect of reforesting becomes important. In most instances where protective forests are neederl, it is posible to une specie- which promise commercial returns as well.

\section{CONMERCINL ISPECTS OF REFORESTING CLEAREI I.AXD}

The chief deterrent to landowners undertaking the project of planting their waste lands to forents is the long interval which must elapse between planting and harvesting the crop. In an analysis of the project of tree plantations as profitable crops. it is necessary to recognize the tremendous accumulative effect of compound interest when carried over a long period, and to draw a general comparison letween the trend in lumber prices as compared to all other commodities.

In computing returns from forest plantations ats an investment, the practice is to regard all money spent for land purchase and plantation development as entitled to a mate of interest which the owner can readily secure by investing in other common phases of business, and, since the periol between disbursement and realization extends over several years, to componnd the interest. The wise of interest calculations permits the owner to establish the value of an acre of land for growing timber and to compare this with the value of other crops which could be secured from the same land. It also enables him to measure the present value of a smo to le received in the future. The mate customarily used in computing farm values is i per cent. It this interest rate and with average yields and stmmpage values, upland soils of average fertility in Jllinos have a value of $\$ 13.95$ an acre when devoter to pine plantations. Land in annual crops needs to net but H(t).(it per acre yearly to give this soil value. But the forest plantation is in the nature of a savings account which draws i per cent interest and which is permitted to rm for a long period, say jo years, at compound rates. In such an account, the sum of the "deposits" consists. of $\$ 13.25$ an acre for land, $\$ 1 ? .00$ for planting, and $\$ 20.00$ for taxes paid at the rate of $\$ 0.40$ yearly. These deposits are considered to earn i) per cent interest compounded ammally, so that at the end of 50 years when the deposits total $\$ 45.25$, the accumulated interest is $\$ 314.95$, and the accomnt amounts to $\$ 360.00$. 
It should be pointed out that while such an accounting is a fair basis for planting projects where land must be purchased and where capital has the choice of other fields of investment, the case of the farm owner is somewhat different. Farms are acquired as units, embracing both good and poor areas. The owner can not separate out and dispose of the waste areas, since no market exists for discomnected fragments of land of this type. He is committed to owning the wasteland and carrying the taxes on it in order to possess that part of the farm from which he gets his revenue. He is already two-thirds in the business, and the decision left for his judgnient is whether the cost of the other third of the project--establishing and carrying the trees-will be amply rewarded. When he considers that plantations in 50 years repay the cost of establishing approximately 30 fold, amounting to an average of $\$ 7.00$ per acre yearly, he is more likely to decide in favor of planting than if he considers compound interest on the land values and taxes.

In approaching the problem of the practicality of devoting areas now cleared to growing wood, it is important, also, to thoroughly appreciate the fact that the present is a period intermediate between a former period of abundant and cheap supplies of high-grade virgin timber and a future period of inadequate supplies of wholly second-growth origin, and that forest crops have increased and should continue to increase in value more rapidly than other commodities. Since 1865 the average price of lumber in the United States has risen 300 per cent while the average prices of other commodities have risen but 40 per cent. The use of current stumpage values in computing the value of a crop which matures in 50 years injects a very conservative element into the computation. The prices of wood products have now reached a level where with certain species the Illinois plantation can return a profit on all but the poorest soil.

\section{Plantations for Production of SaW-logs}

Plantations for the production of saw-logs offer a profitable use for low-grade lands, but only those species can yet be profitably used which have an exceptionally high growth-rate and value. The native hardwoods are not profitably used for restocking denuded upland areas. Even under natural seeding to hardwood and with no planting cost incurred, the long period required to produce hardwood saw-logs and the small yields per acre result in decidedly low returns. Recent studies of growth rates in this State place the average yield of well-stocked even-aged stands of native hardwoods on upland loams at 60 years as $6,144 \mathrm{~B}$. F. to the acre. The stumpage value scarcely totals $\$ 75$ an acre. Pine plantations on similar sites produce $30,000 \mathrm{~B}$. F. in 50 years, or a stumpage value of $\$ 360$ per acre. If planting is necessary in each case, the cash outlay on an acre of hardwood is $\$ 12$ planting cost and $\$ 24$ taxes; on pine, $\$ 12$ plant- 
ing cost and \$?0 taxes. The hardwood pays an average oi $\$ 0.65$ per year over money spent for taxes and planting: the pine returns ten times as much. or $\$ 6.50$. The interest rates eamed on these costs properly compounded over the period represent slightly better than $1 \frac{1}{2}$ per cent for hardwood and slighty better than 6 per cent for pine.

\section{GROWIAG CONIFEROE PLAXTIXG STOCK}

In those States which have developed tree nurseries, suitable planting stock can nsually be secured cheaper than it can be raised. This State is just developing such murseries. and the supply from private concern. is uncerain and expensive: consequenty. the Illinois landowner must grow his own. (Tree seeds can be jurchased from concerns listed on p. 1, . .3.1

The seedbed should preferably be located at a point convenient to work and where water can readily be supplied in dry period. A sandy loam is best. and ahmont any fertile soil is acceptable. but the land should not be fertilized with fresh manure or line. The seedbed should be thoroughly tilled and the soil pulverized and leveled off in beds. A convenient width of the beds is about $t \mathrm{ft}$. This allows access from the margin and is suitable for the adju-tment of sharling trames. -tbout joo trees per ruming foot of bed can be raised in bed-s of this width.

Fall sowing is preferable to spring sowing, beanse the gemination of seeds which have lueen in moist soil over winter is higher. If. howerer, planting is done in spring. germination can be increased by soaking the seeds in water for about a week beiore sowing. The seeds can be sowed in row spaced about $j$ inches apart and rumning crosswise of the bed. The drills should the ahout one-half inch deep. and the number of fresh seed to be sowed per linear foot of drill is shown in Table NII.

T.ITIE XII.

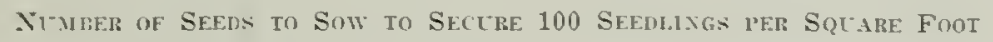

\section{Conifers}

\begin{tabular}{|c|c|c|c|}
\hline Species* & $\begin{array}{l}\text { No. of } \\
\text { seeds } \\
\text { per lb. }\end{array}$ & $\begin{array}{l}\text { No. of seedlings } \\
1 \mathrm{lb} \text {. of seed } \\
\text { will produce }\end{array}$ & $\begin{array}{l}\text { No. of seed per run- } \\
\text { ning foot of drill to } \\
\text { produce } 100 \text { seedlings } \\
\text { per sq. ft. }\end{array}$ \\
\hline Eastern red cedar....... & 17,000 & 6.000 & 120 \\
\hline European larcli ......... & 60.000 & $5.000-10.000$ & 331 \\
\hline Jack pine ............. & 150.000 & $15.000-35.000$ & 276 \\
\hline Red pine .............. & 54,000 & $20.000-30.0610$ & $\$ 3$ \\
\hline Easteru white pine...... & 26.000 & $\$ .000-14.000$ & as \\
\hline Norway spruce ......... & 60.000 & $14,000-35,000$ & 103 \\
\hline
\end{tabular}

Facet on Table 2. Farmers Butletin $\overline{7453 .}$ t. S. Dept. Agr. 


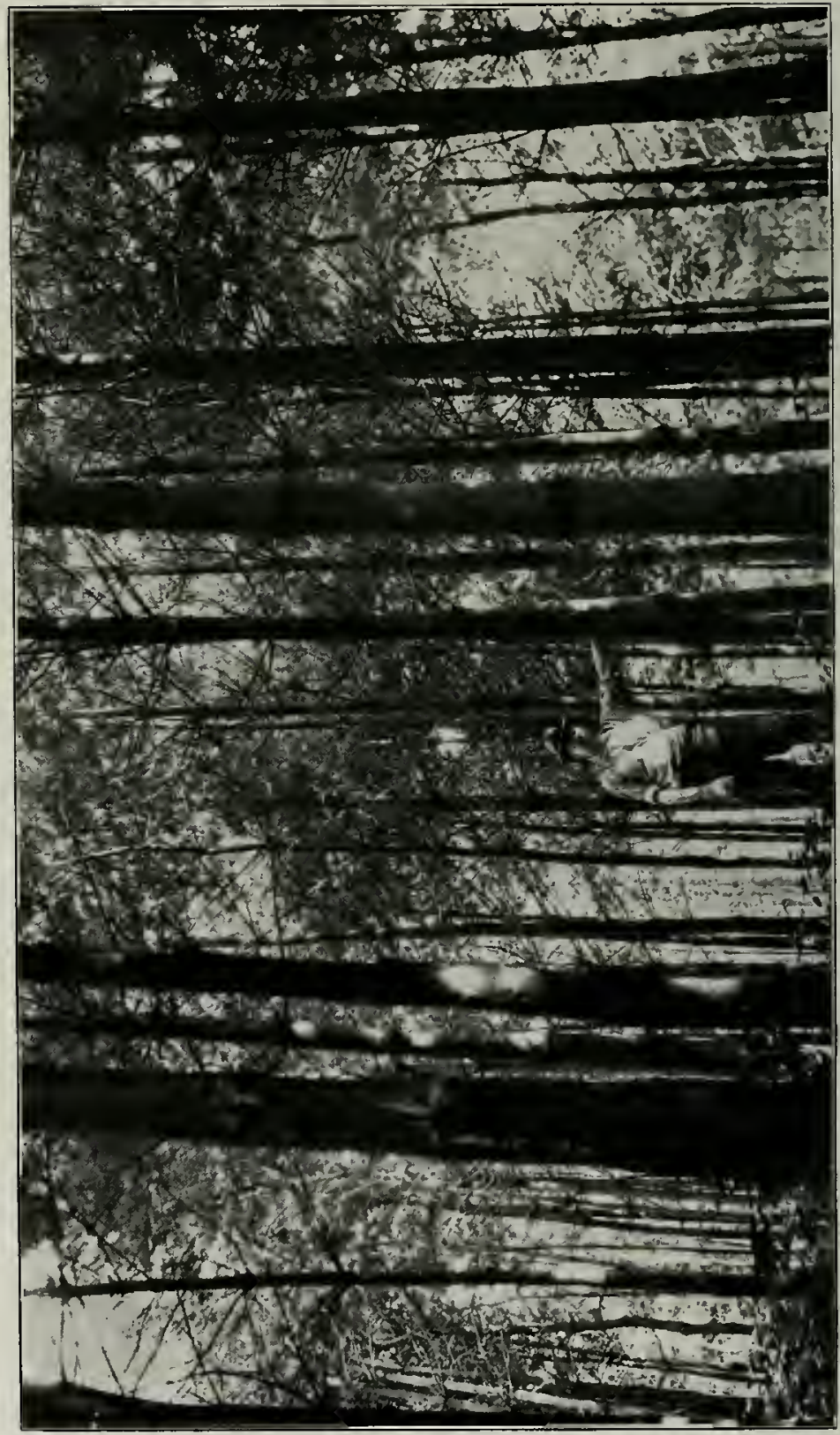


The seeds should be corered with one-fourth to one-half inch of pulverized soil and this in turn with a mulch of straw leaves, or burlap, The mtnch must be renoved in spring as soon as seedlings appear, and shade should be provided for most coniferous seedlings at this stage. A good iramework to support the shading material consists of two-by-fours driven into the gromel at the corners of the bed, so that about ? 0 inches projects above ground, and connected by one-by-four strips nailed near the top of each stake. This forms a support across which can be placed the brush, boards, or lath used to supply shade. By this arrangement the layer of shading material will be about 20 inches above the seed bed. Shading is essential from the time the seedling emerges until well into the first summer. Complete shading, however, shothld never be supplied, hut the material should shut off only about half of the sunlight. After the first year the trees should stand full sunlight. The beds should be kept free from weeds, and during dry periods they must be watered. although the ground should never he kept water-soaked.

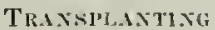

The trees can be left in the seed bed dtring two growing seasons, then either planted directly in the plantation or set out in transplant heds. Spruce rlevelops so slowly that it is uswally arlvisable to set it in transplant beds for one or two growing seasons. On such adverse sites as pure sands, loams where a rank weed and grass growth prevails, or gullied uplands where bare soil is exposed to the drying effects of sun and wind, pine transplants should be used; but on the ordinary upland loamy cleared fields pine socdlings can be successfully used.

Transplanting from seedling bed to transplant bed may lie done after either the firt or second season's growth. The soil of the transplant beds should he wcil tilled. The heds can be if feet wide, the trees are spaced 2 inches apart in a row, ant the rows are 6 inches apart. Such a bel contains i? plants for each linear foot of berl. Transplanting is facilitated by using an inch board in inches wide and of feet long. with notches cut two inches apart along one edge to hold the seedlings. (See figure.) I row of holes one-fourth inch in dianeter is bored one-half

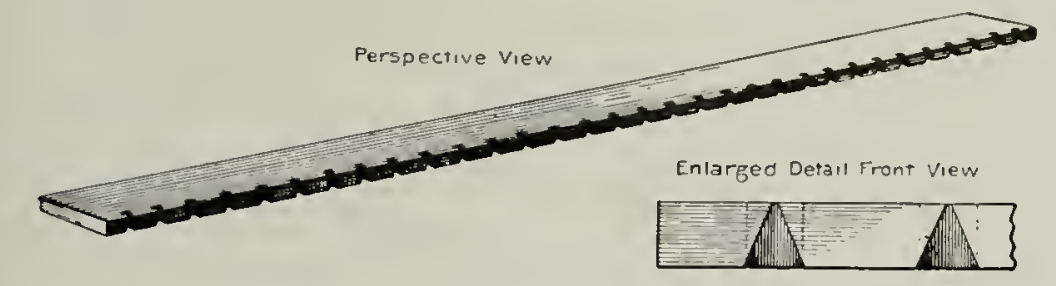

Transplant board*

*From r. S. Dept. Agr. Bull. 1453. 
inch from the edge, two inches apart. Wedge-shaped slots are cut from the edge to the holes, the base of the wedge at the underside of the board being three-fourths of an inch and the apex on the top side having a width about the same as the one-fourth inch hole.

Transplanting may be done either in fall or spring. If dry, both seed bed and transplant bed should be well soaked in order to soften the soil. Carefully lift plants by inserting a spade fork between the rows, thrusting it deeply under the roots, and, as the handle is forced back, pulling gently on the tops. If too much force is used, the roots will be so damaged that the seedlings will die. The roots should be kept constantly moist until replanted. The trees can be placed in a basket and the roots well wrapped with wet burlap or moss. It is not advisable to place the roots in water, as it should be the ain to retain as fully as possible the soil particles which surround roots when the trees are lifted from the bed. Poor specimens should be discarded, and the rest immediately transplanted. The transplanting hoard is placed across the bed, the unnotched edge serving as a marker. The trench is dug along this edge to a depth of at least 6 inches. the spade being thrust vertically down along the edge of the board and the excavated earth placed directly in front of the trench. The board is now reversed so that the notched edge is over the trench and the back of the notch is flush with the vertical side of the trench. The seedlings are then placed one to a notch in a vertical position. The lower leaves hold the crown above the board and the trench is now filled with earth which is tramped firmly about the roots. To remove the board, grasp the unnotched edge and pivot it forward on the notched edge and draw it slowly backward. Repeat the process for each row. Before finishing for the day, water the plants set out that day. The beds should be kept free from weeds and in periods of unusual drought should be watered. Trees carried over the winter in transplant beds do not need to be mulched.

The trees may be removed from the seed bed or transplant bed to the plantation either in fall after the conchusion of the season's growing period or in spring before growth starts. On sandy sites chere is a slight advantage in fall planting; but on heavy soils fall-planted stock is often heaved by frost, so that spring planting is preferable. On the ordinary upland loans it becomes more a matter of convenience. If the site is so unfavorable as to require transplants, it is advisable to use stock which has been in the seed bed one year and in the transplant bed two years, that is, stock about 6 inches high, but it is rarely economical to use stock which is a foot or more high.

A discussion of the methods of establishing plantations and the kinds of trees which are recommended for the different soils follows.

CONIFER PLANTATIONS ON SANDS

Red pine ( $P$. resinosa) and white pine $(P$. strobus) will grow well on most Illinois sands; but if the site is exceptionally dry and exposed, 
Tack pine ( $P$. banksiana! should be used. Either red or white pine produces very excellent lumber. Probably preference should be given to red pine on sancly sites as it grows naturally under these conditions and is not susceptible to insect and disease damage to the same degree as white pine. Yet there is no reason why white pine slould not be used, as it has demonstrated its ability to produce good yields on Illinois dune sand, and effective control can readily be secured if the white pine blister rust becomes estallished in Illinois. Spruce and tanarack are not adapted to siltd.

On areas where the sand drifts, it is advisable to establish a windbreak on the windward side of the area to be planted. The ordinary cottonwood, or Carolina poplar, has the required adaptability, as it sends out roots from the parts of the tree which becone luried by sand rrift. This specien also grows with "relative vigor on dune sands, A windbreak of three rows of poplar with the trees spaced 8 by 8 feet usually suffices to stop) the sand particles. Rooted cuttings (describer on p. 15t) nnay be used. On sandy areas the sparse grass cover is not an impossible barrier to transplants. If the plow can be used, a single furrow should be plowed, and the planter: should follow this immediately and plant the trees in the furrow. The soil should not lave time to dry between the plowing and planting. Transplants rather than seedlings should be used, and the proper safeguards should be taken to prevent root drying when the plants are out of the ground.

The furrows should parallel each other at 6 -foot intervals, and the trees should be planted at 6 -foot intervals in the furrow. This spacing of $t i$ fect loy 6 feet makes a total of 1,210 trees required for an acre. Spacing can lie measured by pacing. In planting, the tree is held in one hand in a vertical position and the roots properly spread; then with the other hand the most fertile soil is spread alonut the roots and packed firmly, care heing taken to renove all leaves and sticks from contact with the roots. The tree should be planted fully as deep as it stood in the nursery. Lastly, some loose sand or litter should be thrown over the topsoil as a protective mulch. If the sand is liable to drift, the furrow should not be deep, as the tree will be covered and die. If the plow can not le used, planting is usually done by two-man teans, one man digging the hole with a grub love or mattock, the other following closely and planting the trees. The man digging loles maintains an even spacing between lines (if necessitry. by placing a stick to serve as a foresight at the end of the row and (i feet from the last row planted) and maintains even spacing between trees within the line by pacing. The earth is scooped out and leposited in a heap at the edge of the hole. If a sod interferes, it should he torn up, making a bare spot about 16 inches square. The planter places the trees properly, as in furrow-planting. Two men in this way plant an acre in a day. Trees respond to cultivation, but usually no further trcatment after planting is given the young plantation on sand excepting the replanting necessary in the following year to replace trees which die. 


\section{CONIFER PLANTATIONS ON LOAMS}

Practically all of the common conifers used in plantations in this region are suited to loams, but the pines are most satisfactory for lumber production, and white pine should probably be given preference over red pine on the heavier loams. Larch and spruce grow well, and a special discussion of spruce for Christmas trees will be given. The loams in Illinois are comparatively fertile, and a plantation can easily be established on unsodded fields. Two-year-old seedlings can safely be used. When a sod occupies the site to be planted. special measures are necessary, as small conifers can not compete with the heavy grass which covers loams in this region. If the a rea can be plowed, the sod should be broken up by plowing a couple of furrows for each row of trees. On heavy soils it is preferable to do this in the fall. leaving the upturned soil exposed to frost and air over winter, and planting the following spring by plowing a single furrow in the center of the double furrow. In this method transplants should be used. The planter should be particularly careful to work the more fertile topsoil against the roots. If the area can not be plowed, the man digging holes should clear a spot about 16 inches square and dig the hole in the center of this. Once the trees become established and the canopy closed-about 10 years after planting -the sod is shaded out and a carpet of needles soon furnishes typical forest conditions.

Conifer plantations for profit should not be attempted under other trees, nor in spots where shade from brush or weeds is dense, nor on heavy, sour, light-colored hardpan soils locally known as post-oals flats, nor on bottomlands subject to inundation.

\section{Citristalas Tree Plantations}

The species most used for Christnias trees are spruce and fir. Of these. Norway spruce is best adapted to handling in plantations. A sandy loam is best, but the ordinary yellow and yellow-gray silt loams of the rolling uplands are entirely satisfactory. The brown prairie loams can be used if well drained. The soil should not be pure sand or a heavy hardpan. A north or east slope not too steep for tillage is preferred, but trees can be grown even on dry southwest exposures which have suitable soils. Cultivation hastens the early growth of all kinds of trees in plantations, and the business of growing Christmas trees warrants the use of land which can be cultivated, although it need not be high-grade crop land. To secure the best returns, the soil should be put in good tilth by plowing and harrowing. Sodded areas should be thoroughly broken, and it is a good plan to raise a crop on such land before planting trees in order to thoroughly work and disintegrate the sod. However, Christmas trees can be raised on land too rough for cultivation. 
Trees may be planted either in autumn or spring on light soils: on heary soils it is preferable to plant in spring. Four-vear-old spruce transplants are recommended. Snch trees will he irom 10 to $1 \mathrm{~s}$ inches high and will be ready to develop rapidly. lonnger transplants and even seedling, can be used, but such trees require irom one to three additional years before good height growth begins. The tree- are spaced in the formation of a triangle three teet on a side. and regular spacing is desirable where later cultivation is applied. This spacing is attained by jowing parallel furrows spaced 31 inches a jart. planting the trees every three feet in the furrow and at a point halt-way between the trees of the adjacent inrrow. For such a three-toot triangular spacing. there are required $\$ 600$ trees per acre.

In all planting operations, precautions are essential to prevent the drying of roots when trees are out of the ground. As each tree is put in place, the roots must be well spread and in contact with moist iertile soil. The soil must be frrmly packed about the roots. and loose soil finally scattered over it to serve as a mulch. The plantation should be cultivated during the first two years.

The variation in height growth is very pronounced in young spruce. The heights commonly in demand are from $t$ to i feet. and the time required to grow spruce to such sizes funs irom $t$ to in years. The usual system is to cut out the larger trees as they become merchantable rather than to attempt to carry the entire-plantation until most trees are merchantable and then clear the area. I small per cent will attain $f$ feet or more after four gruwing seasons, and $! n$ per cent shonld reach this height before the eighth growing season. To special irrigation or fertilization is desirable. as trees growing more than one foot a year do not have the compact form desired in Chri-tmas iree-

Christmas tree plantations should prove profitalle when located near a market, especially when the production is carried on with sufficient regularity to assure dealers a sustained smpply.

The cost of vigorous four-vear-old transplants when purclused from private nurseries is prohibitive for plantation stocking. and since Illinois has not yet perfected a state-owned nursery, the planter must grow his own stock from seed. The methods are described on 1pp. 145-14s. The trees shonld be left two years in the seedbed and two vears in the transplant bed. Seed costs approximately se.st per pound, and one pound shonld prodnce ?., 1100 seedlings--at least enough transplants for 3 acres of plantation. The disadvantage is that eight years are required to produce marketable trees from seed. In most States suitable transplants can be secured from the state nurseries at rates up to $51 . \mathrm{s}$ per thonsand. and at such rates this stock is profitably used. The returns begin 
after four growing seasons, and at an average price of $\$ 0.50$ per tree the acre shows the following gross returns:

\begin{tabular}{|c|c|c|}
\hline Year* & No. of trees harvested & Gross value \\
\hline $4 t h$ & 1000 & 500 \\
\hline 5 th & 1000 & 500 \\
\hline $6 \mathrm{th}$ & 2000 & 1000 \\
\hline 7 th & 940 & 470 \\
\hline & Total & $\$ 2470$ \\
\hline
\end{tabular}

* An allowance of 12 per cent, or 660 trees, is made to cover loss in growing stock and trets which fail to attain a merchantable size in 7 years.

These returns of $\$ 2+i 0$ per acre are based on the wholesale price to the retailer. on the assumption that the owner of the plantation will deliver his trees direct to the retailer. Trees can be cut, bundled, and delivered within a reasonable distance, for 1 ; cents each, netting $\$ 1: 29$ per acre. Against these receipts must be balanced the costs of plowing and subsequent cultivation, which average $\$ 12$; of transplants, $\$ 84$; of planting. $\$ 35 ;$ and taxes at $\$ 1.50$ anmually carried seven years to the maturity of the project. IThere a ; per cent interest rate is used in all computations, the entire project gives an amual return of $\$ 208.80$ per acre for the use of the land.

\section{Cottonwood Plantations on Bottomland}

As stated above (p. 130), cottonwood grown in plantations on bottomlands yields larger quantities of wood in a shorter period than any other native tree. The area to be planted must be as completely cleared of brush and weeds as for field crops. Planting stock is of three kinds: (1) direct cuttings. (2) seedlings, and (3) rooted cuttings.

Direst cuttings are used on the more fertile, mellow, bottonland soils where a good supply of moisture is available. Cuttings are talien from vigorous trees growing in the neighborhood, preferably from the top of the tree. The growth of the preceding year is best, and that of the second year is acceptable. but good results can not be secured by using wood older than two years. The branches are cut during the dormant season and should be subdivided into lengths averaging about 18 inches by cuts made at a $15^{\circ}$ angle with a sharp knife. These cuttings are tied in bundles of 50 or 100 , with the tops all one way. Care should be exercised to avoid breaking off the buds. If made in autumn, these cuttings should be buried over winter below the frost line in moist sand, and they should not be allowed to dry out whether cut in spring or fall. It is also advisable to bury spring-cut stock for 2 or 3 weeks in moist sand, with the large end but an inch or two from surface. This process facilitates the callousing of the cut surface from which roots are sent out. 
The method of planting consists merely in sticking the larger end of these cuttings into the ground to a depth of about a foot. No preliminary plowing or digging is done as the cuttings can usually be pushed directly into the soil. When the soil is not loose, it may be necessary to make a hole with a stick or iron rod. This is the cheapest planting method commonly employed and is well suited to fertile, mellow, moist soils free from weeds and brush. The cuttings should be planted as soon as the frost leaves the ground in spring. When this is done in a wet period, excellent stocking results.

Secdlings are recommended for intermediate sites, where soil or moisture conditions are neither exceptionally favorable nor adverse. Wild stock can be collected, or seedlings can he grown. In collecting wild stock, one-year-old scellings average $12^{\prime \prime}$ to 18 " in height should be lifted in spring before growtl starts. In favorable circumstances this stock can be tumed out with a plow, but ordinarily a spacte can be used to adrantage. Collecting should be done while the ground is soft and moist, and precautions must be taken to keep the roots moist until replanted.

If seedlings are to be grown, a seed bed of rich loam should be selected and the soil thoroughly worked. pulverized, and then rolled smooth. Small branches heavily laden with seed callins are cut from the seed tree just hefore the pods open. At this time it may he necessary to cover the beds with paper or any material which will hold the buoyant seeit on the plot. When the poils open, shake seed out on a calm day. The bed should be evenly covered with a very thin layer of cottony seed, then just enough dry soil sifted over this to bicle the cotton from view. Next, thoroughly siturate the seelled, using a spray. Cover the moistened suface with japer nutil the seedlings appear. Ifter this the paper should be removed, but the bed should be kept moistened, as the surface soil must not become dry before the tiny seedlings have developed deep taproots. If the stock seeds in thicker than 20 trees to the square foot. it should he thimned. This stock should be taken up and planted the following spring before growth begins. It will then be about ? feet tall. It is important to lieep the roots moist cluring the interval between lifting from the bed and replanting

Seerlings are planted as follows: a hole about 6 inches wide and fully a foot deep is dug with a narrow spale, the roots of the seedling are well spread. and the loose eartls is packed firmly about them. The seedling should be set fully as deep as it stood in the beri.

Rooted cuttings are recommended for sites where soil and moisture conditions are not well suited to the establishment of cottonwood. This stock is bulky, costing more to handle than either calloused cuttings or seedlings. On sandy or gravelly soils where the water table is not cluse to the surface, or on fertile sites where vigorous weed growth is not 
controlled, rooted cuttings are necessary to insure the establishment of a fully-stocked plantation. For growing this stock, branches should be cut into lengths of about 1 foot and set in a well-tilled sandy-loan bed to a depth of ! inches. At least one good bud should project above ground. Space 6 inches in a row with a foot between rows. Keep free from weeds and well moistened during the growing season. Plant the following spring before growth begins. Planting requires digging the hole for each tree as for seedlings, but the process can be cheapened by the use of a plowed furrow on those areas where a plow can be used. The spacing for all forms of planting stock should be 10 feet by 10 feet when logs are to be produced, and 8 feet by 8 feet for pulpwood. This is 440 and 680 trees per acre, respectively.

The exceptional growth and unusual intolerance of cottonwood results in an early struggle for light and the early suppression of all but the most vigorous trees. Pure stands of cottonwood open up at an early age, creating light conditions favorable for less-exacting trees and weeds. Cottonwood responds to increased light conditions resulting from a thinning. but after the sapling stage the canopy of a pure stand opens up so much naturally that the benefits of increased growth on the trees left in a thinned stand are somewhat nullified by the increase in weeds and brush which follows such a thinning. When thinnings are made they should be light. The main crop should be harvested in a single cutting, all brush and under-growth being cleaned out at the same time, and the area should be immediately restocked with cottonwood before a heavy growth of other species makes clearing costs prohibitive. An idea of the number of trees naturally found at different ages on fullystocked cottonwood stands can be had from an inspection of coltunn 2 in Table XIII (p. 15.j).

Planting an understory of soft maple and elm has been practiced as a means for utilizing all the light for tree growth and for keeping out the weeds. On floodlands a well-shaded forest floor is not essential to the maintenance of soil fertility. since such fertility is renewed by repeated soil deposits rather than by the decay of forest litter. The growth of the understory must be cleared off at the time that the overwood is harvested if a new stand of cottonwood is to be established: and since such growth is relatively slow and is not of merchantable size, growing an understory is a cuestionable practice in managed cottonwood stands on floodlands. Weeds and trees which seed in naturally, do not greatly influence the development of a crop of cottonwood on fertile bottomlands after it is well started.

The yields given in Table XIIl can be secured from cottonwood plantations on the floodlands of the IVabash, Ohio, and Cache, and on the Mississippi up to about Alton. On Mississippi bottomland in Union County a yield of $5.1 i+$ B. F. per acre harvested for veneer logs from 18 -year-old trees compares very favorably with the $4.100 \mathrm{~B}$. F. yield in the table. Yields on the Kaskaskia, Illinois, and upper Mlississippi bottomlands are somewhat lower. 
Logi delivered at the mills average about $\$ 25$ per thousand (Doyle Rule). The 1924 price for logs delivered on the river hank at a landing in southern Illinois was $\$ 17$ per thousand. The trees are grown on the floodlands outside the levees: consequently. the haul is short and \$.5 per thousand is a fair logging cosl. Table XIII show's the vields and the returns received at these values.

\section{TAIBLE XIII}

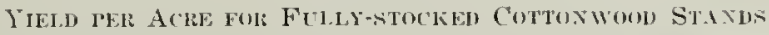

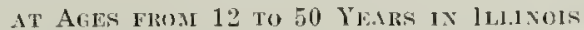

\begin{tabular}{|c|c|c|c|c|c|c|c|}
\hline Yrs. & $\begin{array}{l}\text { No. of } \\
\text { trees } \\
\text { per A.* }\end{array}$ & $\begin{array}{l}\text { B. F. } \\
\text { yield } \\
\text { per A. } \\
\text { (Doyle } \\
\text { Rule)* }\end{array}$ & $\begin{array}{l}\text { Gross } \\
\text { value } \\
\text { of } \operatorname{logs} \\
\text { per } \mathrm{A} . \\
\text { at } \$ 17 \\
\text { per } \mathrm{M} .\end{array}$ & $\begin{array}{c}\text { Cost of } \\
\text { logging } \\
\text { per } \mathrm{A} \text {. } \\
\text { at } \$ 5 \\
\text { per } \mathrm{M} \text {. }\end{array}$ & $\begin{array}{l}\text { Accumulat- } \\
\text { ed tax and } \\
\text { planting } \\
\text { cost per A. } \\
\text { An. Tux } \$ 0.40 \\
\text { I"lantim } \$ 9.08 \\
\text { lnterest } 5 \% \\
\text { compundel }\end{array}$ & $\begin{array}{l}\text { Returns } \\
\text { per } \mathrm{A} \text {. } \\
\text { above log- } \\
\text { ging, plant- } \\
\text { ing, and } \\
\text { tax costs }\end{array}$ & $\begin{array}{l}\text { Maximum to } \\
\text { be spent lor } \\
\text { buying and } \\
\text { clearing } \\
\text { lands at } 5 \% \\
\text { compound } \\
\text { interest }\end{array}$ \\
\hline 1 & $\therefore$ & 3 & i & 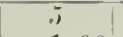 & 6 & $i$ & is \\
\hline 12 & 452 & 200 & 3.40 & 1.00 & 22.68 & -20.28 & $\ldots \ldots$ \\
\hline 13 & 375 & 700 & 11.90 & 3.50 & 24.20 & -15.80 & $\ldots \ldots$ \\
\hline 14 & 320 & 1,300 & 22.10 & 6.50 & 25.82 & -10.22 & $\ldots \ldots$ \\
\hline 15 & 276 & 1,900 & 32.30 & 3.50 & 27.51 & -4.71 & $\ldots \ldots$ \\
\hline 16 & 243 & 2,600 & 44.20 & 13.00 & 29.28 & 1.92 & 1.62 \\
\hline 17 & 217 & 3.300 & 56.10 & 16.50 & 31.15 & 8.45 & 6.54 \\
\hline 18 & 195 & 4,100 & 60.70 & 20.50 & 33.10 & 16.10 & 11.44 \\
\hline 19 & 178 & 4,900 & 83.30 & 24.50 & 35.16 & 23.64 & 15.48 \\
\hline 20 & 163 & 5.700 & 96.90 & 28.50 & 37.32 & $31.0 \mathrm{~s}$ & 18.80 \\
\hline 21 & 150 & 6.500 & 110.50 & .82 .50 & 39.59 & 38.41 & 21.50 \\
\hline 22 & 140 & 7,5011 & 127.50 & 37.50 & 41.96 & 48.04 & 24.95 \\
\hline 23 & 130 & $S .400$ & 142.80 & 42.00 & 44.46 & 56.34 & 27.20 \\
\hline 24 & 121 & 9.500 & 161.50 & 47.50 & 47.08 & 66.92 & 30.07 \\
\hline 25 & 114 & 10,700 & 181.90 & 53.50 & 49.84 & 78.56 & 32.92 \\
\hline 26 & 106 & 12,000 & 204.00 & 60.00 & 52.72 & 91.28 & 35.72 \\
\hline 27 & 99 & 13.400 & 227.80 & 66.00 & 55.77 & 106.03 & 38.80 \\
\hline 28 & 92 & 15.100 & 256.70 & 75.50 & 58.95 & 122.25 & 41.86 \\
\hline 29 & 86 & 17,100 & 290.70 & S5.511 & 62.30 & 132.90 & 42.65 \\
\hline 30 & 80 & 19,200 & 326.40 & 96.00 & 65.81 & 169.59 & 49.59 \\
\hline 31 & 75 & 21,400 & 363.80 & 107.00 & 69.50 & 187.30 & 52.94 \\
\hline 32 & 70 & 23,500 & 399.50 & 117.50 & $73.3 \mathrm{~s}$ & 205.62 & 55.41 \\
\hline 33 & 66 & 25,300 & 430.10 & 126.50 & 77.45 & 226.15 & $56.4 !$ \\
\hline 34 & 62 & $26,600^{\prime}$ & 452.20 & 133.00 & 81.73 & $2: 37.47$ & 55.83 \\
\hline 35 & 59 & 27,500 & 467.50 & 137.50 & 86.21 & 243.79 & 53.98 \\
\hline 36 & 57 & 28,200 & 479.40 & 141.00 & 90.92 & 247.45 & 51.64 \\
\hline 37 & 53 & 28,700 & 487.90 & 143.50 & 95.87 & 248.53 & 48.91 \\
\hline 38 & 51 & 29.100 & 494.70 & $145.50^{\prime}$ & 101.06 & $24 S .14$ & 46.07 \\
\hline 39 & 50 & 29,300 & 498.10 & 146.50 & 106.52 & 245.08 & 42.96 \\
\hline 40 & 49 & 29,300 & 498.10 & 146.50 & 112.24 & 239.36 & 39.63 \\
\hline 50 & 32 & 29,400 & 499.50 & 147.00 & 187.56 & 164.94 & 15.75 \\
\hline
\end{tabular}
Valley" 


\section{Perion ror Most Profitable Harvest}

Table XIII has heen worked ont in detail in order to show the importance of the time element on bath the amount of wood grown and the net returus received. The annual tax of $\$ 0.40$ per acre and the planting cost of $\$ 9.0 \mathrm{~S}$ both approach maximum costs for the umprotected floodlands used for this purpose in Illinois. Where money is spent for taxes and planting costs and when returns are deferred for a period of years, compound interest at 5 per cent has been charged.

The stand first contains trees of a merchantable size at the age of 12 years, when the yield is 200 B.F. per acre. as showu in column 3. The merchantable contents added thereafter increase yearly nntil the amount of merchantable contents grown in the 31 st year $(2200 \mathrm{~B}$. F.) is more than four times that grown in the 13 th year $(500 \mathrm{B.F}$.); atter the 31 st year the rate of increment decreases rapidly, and virtually no increase in yields occurs after 40 years. The folly of cutting a stand of 20-year-old cottonwood for a yield of 5,700 B. F. per acre becomes apparent when it is seen that an additional growth of $13,500 \mathrm{~B}$. F. can be secured if the stand is allowed to grow another ten years. Expressed in money the wood grown in the first 20 years has an average gross value of $\$ 4.84$ per acre annually, but in the next ten years the wood grown has an average gross value of $\$ 22.95$ per acre annually.

The rapid increase in carrying costs, due to compounding the interest on money actually expended, is apparent in column 6. At 18 years approximately half of these costs, or $\$ 16.28$, is actual dishursement, and the rest, or $\$ 16.82$, is interest; at 33 years the interest amounts to 71 per cent (\$55.17) of the carrying costs ( $\$ 77.45$ ); and at 39 years, the interest has climbed to $\$ 82.02$, or 77 per cent of the carrying costs. This rapid increase fixes the period for most profitable harvest well in advance of the time when the volume of wood in the stand reaches its maximum amount. Thus, according to column $\mathrm{s}$, in which land cost, planting cost, and tax cost are calculated, with 5 per cent compound interest, the most profitable time at which to cut the stand is at 33 years. although the maximum merchantable content of the stand does not occur before 39 years, as shown in column 3. In other words, under the approximately average yields and costs shown in this table, cottonwood reaches its financial maturity at 33 years, paying 5 per cent interest compounded on a total investment of $\$ 78.77$ per acre for land, planting, and taxes.

\section{Penntations for Post Production}

The farm owner who is considering the advisability of establishing a plantation of trees to supply his posts is confronted with this problem: he can consider one of the five durable species each of which has at least one serious limitation, or he can decide to treat his posts with a preservative and grow any of a half-dozen species well suited to this purpose because of rapid growth rates, insect immunity, and ease of culture. 
The five durable species commonly used are catalpa, liack locust, Osage orange, mulberry, and red cedar. Ilthough very lapid growth produces posts of low durability, yet posts from these species have an average durability of 1 is years or more. Red cerlar, although it will grow on thin sterile soils, is scarcely to he consilered because of its slow growth*. Mulluerry repuires a fertile soil, freezes back in winter. and develops a bushy form not suited (1) post pruduction. (Jage orange is very chrable and has been freely plinted as a hedge, lout develops both poorly and slowly when planted in groves. Black locust han all the qualities of durability, rajuid growth rate, adipltaloility to a wile range of soils, and proper form, but it has two inseet enemies which have discounted its usefulness. Catalja has a rapid growtl rate, durability, and suitable form, but reguires a fertile soil, and has one serious insect enemy.

\section{C.ITALPA}

Most failures in catalpa plantations in lllinois can le tracel either to planting the trees on soils not suited to the species, to the use of the wrong species, or to insect attacks. Catalpa plantations show excellent returns, but only on high-grade fertile soils. The upland locations where eatalpa will succeed are limited to decp, well-(lrained, fertile soils. It grows well on fertile prairie loams, Jut it is not recommended for ordinary light-colored soils of the upland, and it should never be planted on exireme types, such as sands or clays. On bottomlands the tree grows well over a wither range of soils, and can be used on both heavy and light loams, but not on extrentes of sands or clays. It is not injured by flooding but is susceptible to frost injury on bottomland sites in the northern part of the State. When grown in pure plantations, it is also defoliated from 2 to 3 years out of 5 ly larve of the catalpa splinx moth.

In spite of its exacting soil requirements, lialility to frost injury, and probability of insect damage, this tree is recommended hecatse in Illinois under proper conditions it jroduces more high-grade posts in a given perior than any other species. It should not le considered for pole or tie products, as it tends to rot freely after the pust size is passed. The average service of posts is 16 years. From $1:$ to 15 years are usually required to produce posts in plantitions, and the average yearly yield approximates 100 jer acre.

The use of a lydrid of the native catalua (Cafalpa spociosa) and the southern catilpa (Catalpa bianonoid's) has invarialy resulted in trees of musatisfactory form. In ordering nuriery stock, insist upon Catalpa speciosa.

It is preferable to select a spot protected from the prevailing winds. because in exposed plantations the trees on the south and west sicles are usually distorted and less thrifty. Catalpa should not be planted

* Studies based on 200 trees in southern Illinois indicate that approximately 50 years are required for cedar to grow to post size. 


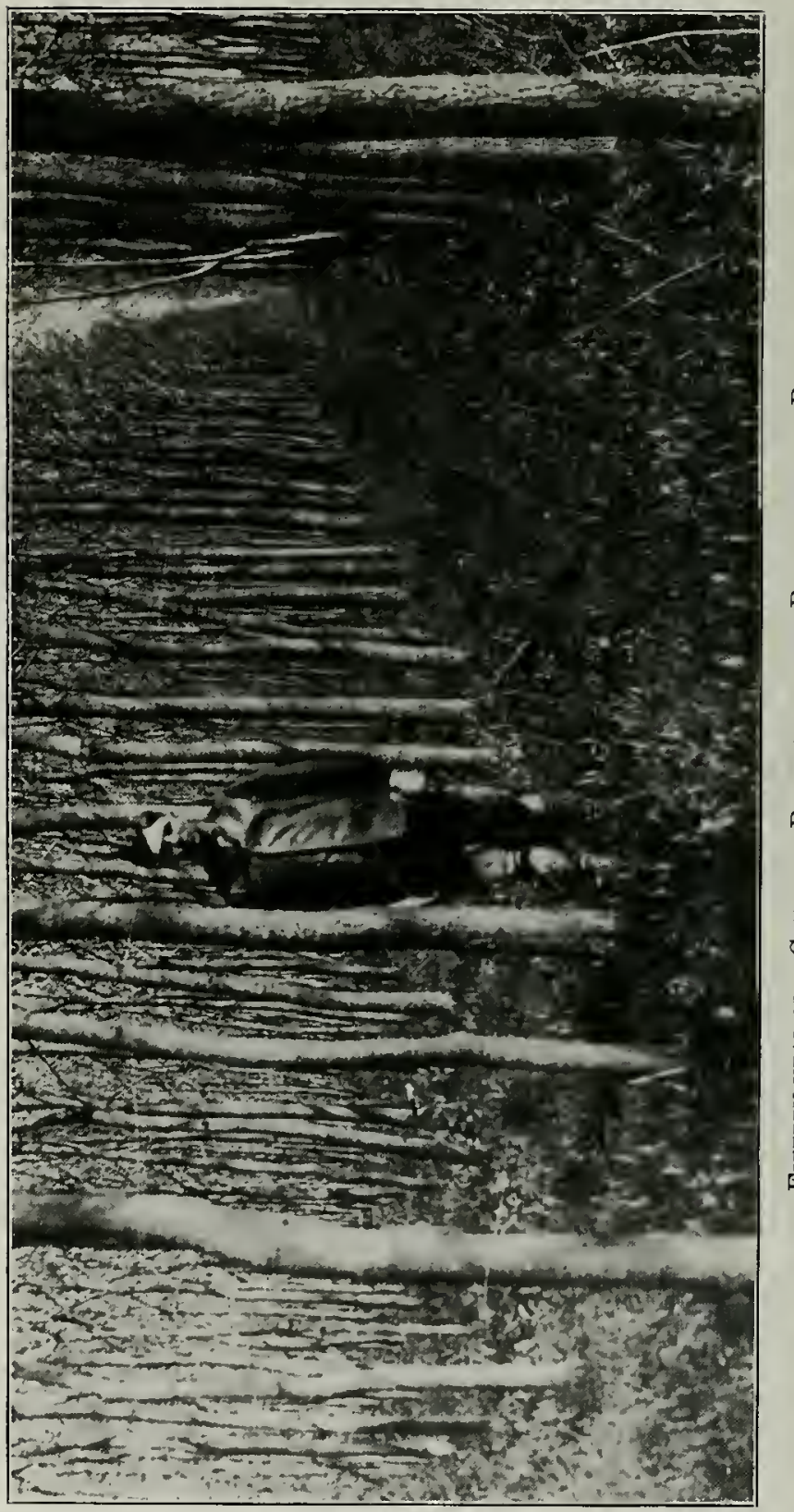


under other trees nor in small openings in native hardwood forest. The cleared area should be plowed, as catalpa planterl in a sod develops very slowly. After plowing, furrows should be run every six feet, and the trees planted three feet apart in these furrows. The roots should be well sprearl in the bottom, loose moist earth placed over them and packed firmly with the foot. After the furrows have been planted, they should be plowed full of eath. This spacing requires 2420 trees per acre.

The plantation should be cultivated and kept clean of weeds until the trees attain a size sufficient to form a closed canopy-at least two years. Proper tillage shortens by several years the time recuired to grow posts.

Catalpa does not naturally develop the straight smooth stem suited to post material. The terminal lud is frequently winter-killed or injured by insects, resulting in a crook in the stem as a lateral branch replaces the terminal. Mlso, the dead side lownches lang to the tree long after they have heen shaded ont. In order to correct these conditions, the young trees frefunenty are cut lack to the gromed during the dormant season after their second year's growth. As sprouts develop, only the most vigorous one on each stump is permitted to grow. This sprout often grows nearly to the same height the first year as the seedling attained in the previous two years, and it forms a straight steni. There is a very good chance, however, that the vigorous sprouts hearing their large leaves will be ruined ly storms or distorted by sheer weight. The same injury also follows a proning off of the live lateral branches for the purpose of forcing the stem to vigorous height growth, and this practice is not recommended. The trees should be planted close together to insure active height growth, and on fertile land to support such growth: as the lateral branches are shaded out and dic, they should be primed off as close to the stem as possible.

At about eight or ten years after the plantation has been set out. it will need thinning. The smaller trees should be cut, taking out between one-fifth and one-third of the total ntmber. The plantation on good soil should produce posts after 1 ? years. The higher yields are secured between 12 and 18 years, and an acre slould average 1110 posts per year since planting. Because catalpa posts are not easily split from larger dianeters but must he sawed, it is usually preferable to cut the trees before they develop large diancters. Some success in reestablishing a new plintation from sprouts is secured if the rows are cut clean in the dormant season. In order to minimize wind injury, it is a good plan to cut rows on the north or east side first and to work south or west in successive years as posts are needed. The old plantation then forms a windbreak. Only one sprout to each stump is usually allowed to grow. but as this practice often results in a very tall shoot unable to support its heavy crown of leaves, it may be arlvisalle to let all sprouts grow fluring the first season and to knock off all but the best one the following winter. 
The plan of management of a catalpa plantation must include control of the catalpa sphinx. This is practical, as an arsenical spray can be applied to the crowns with a hand punmp in those years when the worms are abundant. The normal defoliations of three years out of five will utterly kill an unsprayed plantation. The effective mixture consists of 4 pounds of lead arsenate to 50 gallons of water, and it should be applied upon the first evidence of the larvae in the plantation.

\section{BLACK LOCUST}

Black locust stock can be purchased cheaply, is easily transplanted, makes rapid growth, and produces very durable posts. The tree develops a very fibrous root system capable of producing new trees from root sprouts. Black locust is one of the legume family and has the nitrifying merits of this family. Perhaps its best quality, however, is its ability to grow on thin, sandy, or eroded soils; as an agent in the reclamation of sterile gullied hillsides or loose sand, it is superior to any other tree. Even though the borers distort or kill the stem, the roots grow vigorously and bind the soil, sending out sucker shoots freely and developing a soil cover as well as enriching the soil with nitrogen.

There are conditions under which black locust plantations are not destroyed by attacks of the borer. Trees which are growing with pronounced vigor seem not to offer suitable conditions for borer infestation in epidemic intensity. Although such trees are usually attaclied, the infestation does not gain such momentum as to destroy them. It is possible for entire plantations to be brought to profitable yields of posts in spite of the locust borer. Pure locust plantations are successfully grown on fertile, well-drained loans, but they are generally destroyed when located on sterile sands or thin loams. On such intermediate sites as gullied uplands or crop-worn fields, special measures will often result in a growth vigorous enough to enable the plantation to resist a borer attack. Alternate the locust with another species, and cultivate the plantation as long as it is possible to drive between the rows.

Black locust should never be planted under an overwood, but it will grow as groups in openings of the forest. It produces posts in about 15 years. A good mixture for the reclamation of gullied uplands or of sand hills and for the production of posts consists of sassafras and locust, planted alternately, as the sassafras offers a certainty of some posts even if the locusts are destroyed. Spacing should be about 6 feet by 6 feet, thus requiring 1210 trees per acre. 


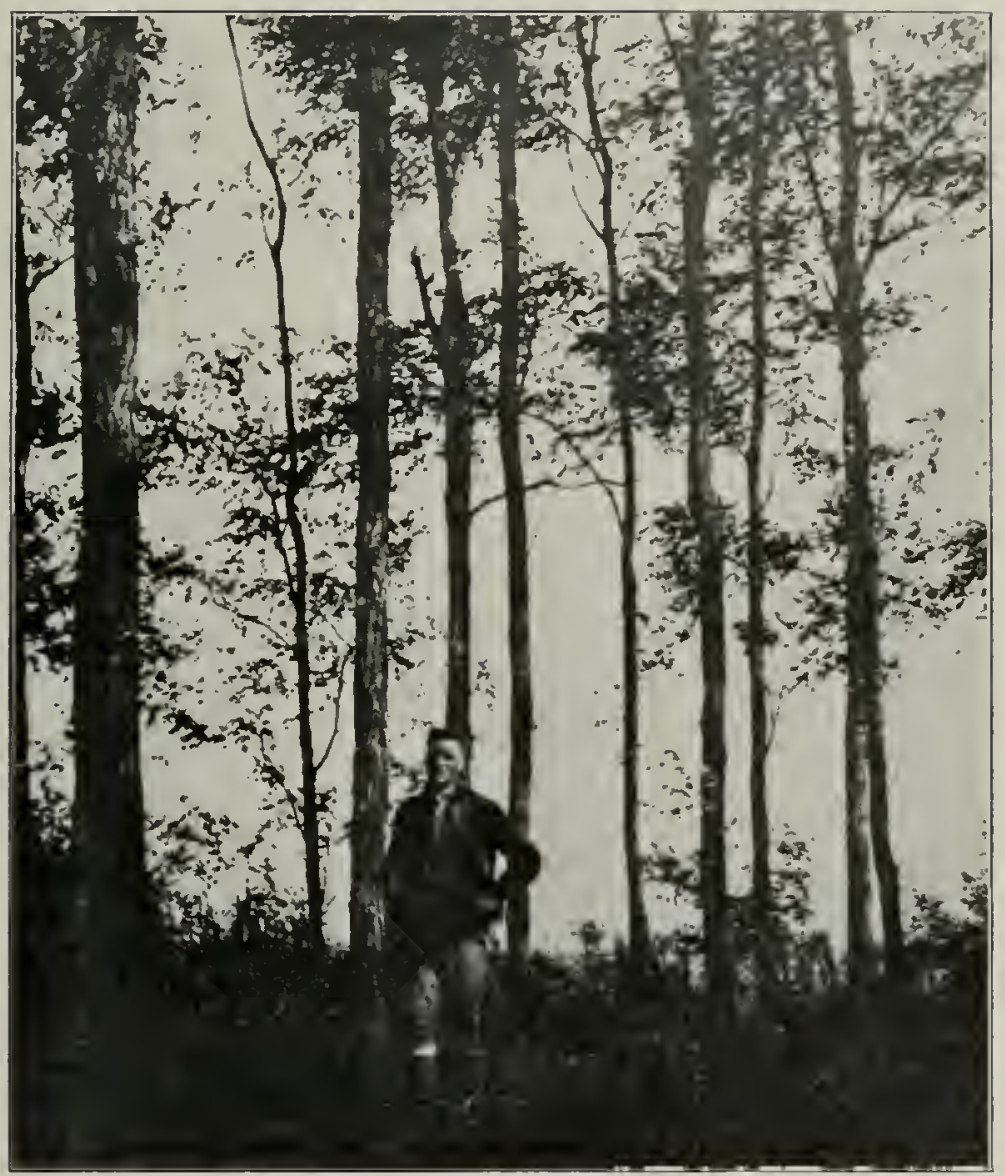

Plixtition for tile Ploncction of Posts.

Twenty-year-old black locust on gullied land. 


\section{OSAGE ORANGE}

Osage orange is less exacting in soil requirements thiun catalpa and more exacting than locust. It will produce posts on sandy and loamy soils which are deep and well-clrained, but it is not suited to extremely heavy, thin, or sterile soils, and it suffers winter injury on bottonlands.

Although Osage Orange posts excell in durability, the growth rate is less than that of either locust or catalpa, and the trees have a pronounced habit of forking close to the ground and producting much-branched and crooked stems. This defect can be corrected by pruning, but the tree has too slow a growth rate to recommend it for extensive plantation work. Osage orange can grow well in situations exposed to drying winds, and the very qualities which bar it from use in plantations make it a very excellent hedge tree. The much-branched form is trimmed to make a living fence, or the trees are allowed to develop full height growth, making a tall hedge which serves as a windbreak. Leaders from the trinmed hedge may be permitted to grow and provide posts at intervals of about three feet.

This species was formerly freely planted about the fields, not only because it served as an excellent fence and provided excess post material, but also because a windbreak was considered a necessity for high crop yields in all sections of the prairie regions. The influence of windbreaks upon crops in adjoining fields is injurious within the zone reached by the shade of the trees and may be injurious over a somewhat wider zone because their roots compete with crops for moisture; for a distance beyond this the influence is generally beneficial. The balance measured in crop yields is entirely in favor of windbreaks in more arid regions but not enough so in Illinois to justify decisively their general use. The past decade has witnessed a transformation in farn management involving the general use of tractors, organized campaigns against weeds and insects, and the effort to utilize fully the crop-producing areas. As a consequence, hedges are in disrepute and during the past few years their removal has been actively carried on; yet many landowners are still interested in growing such hedges.

Seedlings can be easily grown on the farm. Gather the hedge apple: in fall and place them in water until the pulp becomes rotten, and then wash out the seeds. Plant the seeds in spring in well-tilled garden soil and, when the seedlings appear, thin so that they stand about three inches apart. Keep free from weeds and transplant to the field in fall or early the following spring. One growing season in the seed bed is ample. For hedges, a two-foot spacing is recommended; for windbreaks, three-foot. If a plantation is the object, plow the area and set the seedlings in rows seven feet apart and five feet in the row. The area should 
be cultivated until the growth of the branches impedes this wark-about two years. The trees should also be pruned, as this species has a habit of developing forks and persistent side branches. If pruning is properly done between the second and fifth years, post production is materially increased. The trees require at least 15 years to grow to post size.

\section{Sundary of Points ox Seed axd Tree Plaxtixg}

Recuforcoment planting in under-stocked natural stunds.-Use rapidly-growing native hardwoods rather than conifers. For oaks and other large-seeded species, plant the seeds where trees are needed. Trees having small seeds are customarily first started in a seed bed and the young trees transplanted whe re needed aiter the first growing season in the bed. Transplant during spring before the leares appear and in spots cleared of bushes and sod. paching fine, moist soil about roots and mulching with litter.

Planting cleard arcas.-For saw timber, conifers should be used on upland sites and broadleaved species on bottomlands. Conifers are grown from 2 to 4 years in the nursery before transplanting in the field. If such trees can not be lought for a cent a piece, they should be grown on the tarm. Plant thickly-6 feet by if feet-to develop trees of good form, and begin thinnings when the lower branches have been shaded out and the plantation reaches the polewood stage-trees from 3 to 8 inches in diameter and $\geqslant 0$ years or older.

In plantations for posts, the relatively durable species recommended are: catalpa for tertile uplands, or for bottomlands except in the northern quarter of the State, and black locust mixed with larch or sassafras on the less fertile soils. For hedge fencing, nothing equals Osage orange. 


\section{MEASURING AND MARKETING WOODLOT PRODUCTS}

In general, the woodlot owner should undertake the marketing of his own products. In so doing, in addition to providing employment for teams and men at a season when farm work is slack, he gets for himself a knowledge of timber values and woodlot management, which is the best guarantee for a permanent and profitable woodlot. Woodlot owners are usually ignorant of the products and grades into which trees can be cut, do not know of the many markets for woodlot products, and are unable to estimate standing timber. For these reasons they frequently sell standing timber for a hump sum below its real value, or turn into cheap products much timber which is suitable for highgrade products. It is a good plan to investigate the markets and estimate the contents of standing timber, even if it is to be sold for a lump sum. Selling by the piece or by board-foot unit rather than for a lump sum is generally more satisfactory, especially if it is possible to get a reliable check on the amount taken.

While it is usually desirable to harvest systematically at regular intervals, as previously explained, yet this practice should be modified when necessary to take advantage of periods of favorable market conditions. Timber holds a unique position as a crop, inasmuch as, within certain limits, it increases in volume and vahe if not harvested. When market conditions are poor, it should be allowed to grow.

\section{Choice of Products}

There are eight principal products grown on Illinois woodlots: cordwood, mine timbers, cross ties, lumber, cooperage and veneer logs, piling, and posts. All forest soils in the State can produce at least three of these products, and most forest soils are generally fit for the production of all eight. Since some of them are much more profitable than others, it is best to choose those from which the highest returns may be had.

Before any comparison of returns can be made, these different products must be reduced to a common unit, for different products are measured by different units : cordwood, by the cord; mine timber, cross ties. piling, and posts, by the piece: logs and lumber, by board feet. These may all be reduced to cubic feet. The average cord contains 80 cubic feet of wood; the average nine timber, 0.606 ; cross tie, 3.0 ; pile, 22.3 ; post, 0.8 ; and $1,000 \mathrm{~B}$. F. in the $\log$ is equivalent to 166.8 cubic feet; 1000 B. F. of lumber to 83.3 cubic feet. Again, in converting the tree into the different products, the owner should consider what portion of it is usable in each case. The amount of stem which appears in the product varies from 32.5 per cent in lumber to 100 per cent in cordwood. The amount of wood to the acre is best expressed as total cubic feet in the entire stems, and the annual growth, or accretion, as the number of cubic feet annually added. Therefore, in order to express the money value of the annual growth worked up into the differ- 
ent products, their value must be comptuted per cubic loot of total stem rather than per cubic foot of manulactured product. This has been done in Table $\mathrm{XV}$ (p. 16i).

The choice of the product or combination of products, in any given case, depends upon the following considerations: (1) per cent of the tree wbich enters into the salable product. (2) relative costs of converting the tree into different products, (3) relative cost of shipping products to market, and (4) relative sale values at market.

(1) The per cent of the total amount of wood in the bole of a tree which enters into the salable product averages as follows: cordwood 100 . piling 85 , mine timber and posts 74 , cooperage and reneer logs 65 , cross ties 49 , and lumber 32.5. It is evident that, if the sale price is similar, the greater returns will come from those forms of product which utilize the greater part of the tree.

(2) The average costs of converting a tree into the different products, in terms of cubic feet of wood in the bole or stem. are as follows: veneer or cooperage logs $\$ 0.0509$ per cubic foot, cordwood $\$ 0.551$, piling $\$ 0.0794$, cross ties $\$ 0.0796$, mine timbers $\$ 0.0808$, posts $\$ 0.0932$, and lumber $\$ 0.0996$. Thus the greatest cost of conversion (into lumber) is 95 per cent greater than the lowest cost (into veneer $\operatorname{logs}$ ), both being measured in cubic feet of the entire stem.

(3) The freight rates vary with the product and the distance. Customarily, cordwood pays the least per hundred pounds, mine timbers slightly more, while rates on piling. logs, posts, and lumber are yet higher. The effect of these transportation costs is to limit definitely the area within which forest products can be shipped. When the costs of manufacture and transportation equal the sale price, the operator has given his product away. At the average sale price of \$5.06 per cord, cordwood cau not be shipped at all. The other products can be shipped distances varying from 100 miles for ordinary $\operatorname{logs}$ up to 500 miles for average lumber produced in Illinois. (See Table XlY.)

(4) Rates of growth per acre and per cents of possible utilization determine the quantities of the different products which can be produced; the respeztive manufacturing aud shipping costs determine the expense of putting the various products from tree to market; and, finally, the respective sale ralues determine the choice of the product. The average cost of manufacturing, the average sale price, and the margin left for profit per cubic foot of product are shown in Table XIV, and from these elements can be computed the shipping zones: but the determination of the relative profit in growing these different products is not based solely upon the cubic feet of product, but involves also relative per cents of the total growth which can be utilized in making these products. In Table $\mathrm{XV}$ this variable degree of utilization has been taken into account by converting all values per cubic foot of the different products into values per eubic foot of the total contents of the standing twe. and the data are tabulated to show stumpage values per cubic foot of the standing tree for timber which is marketed at average prices (1) with no freight cost. (2) with a 25-mile haul. and (3) with a 100-mile haul. This table, giving weight to degree of utilization as well as costs, more nearly expresses the ratings of the different products from the viewpoint of the producer. 


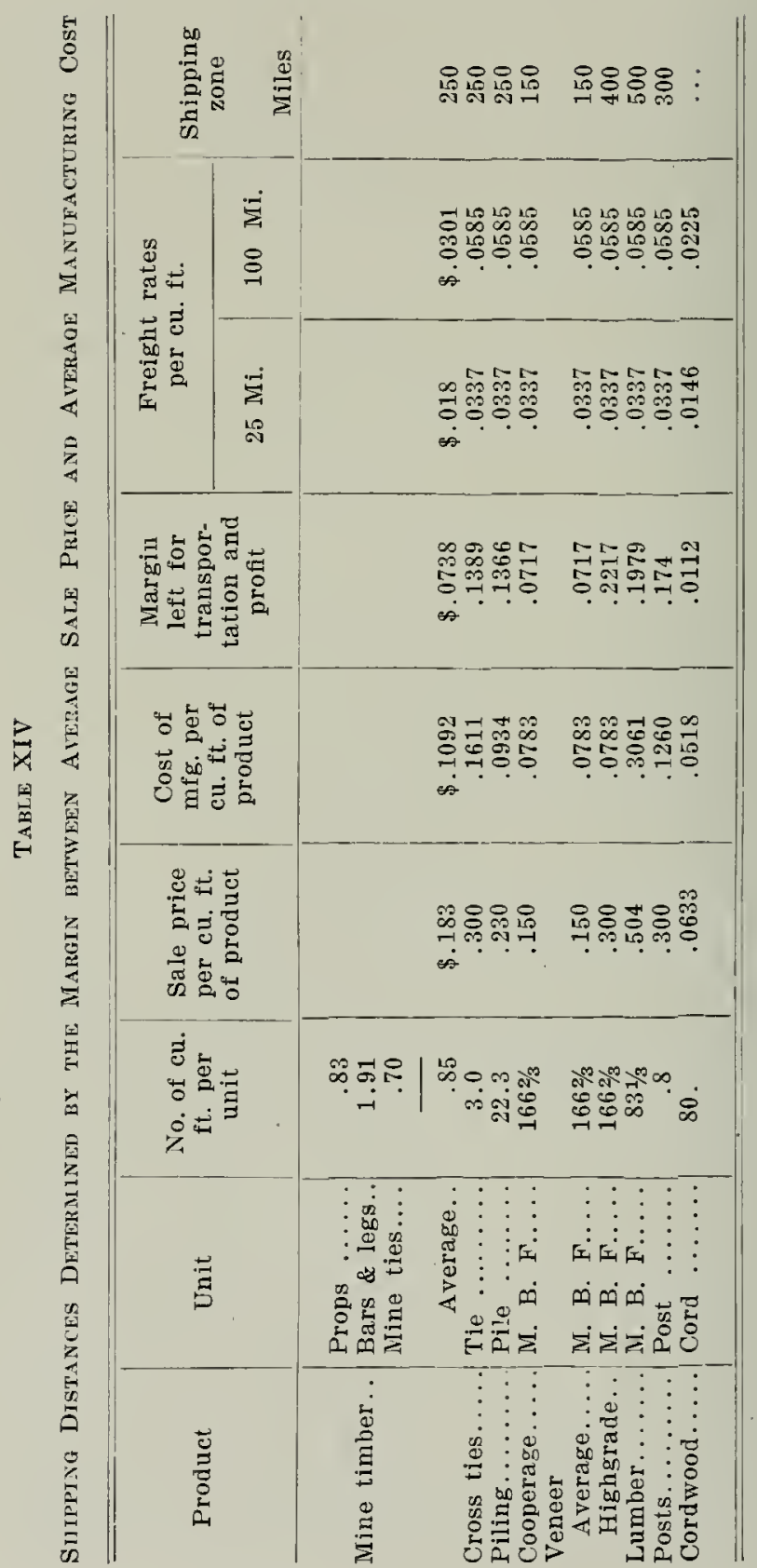


A MAxull of WoOdLot MAxagemFix

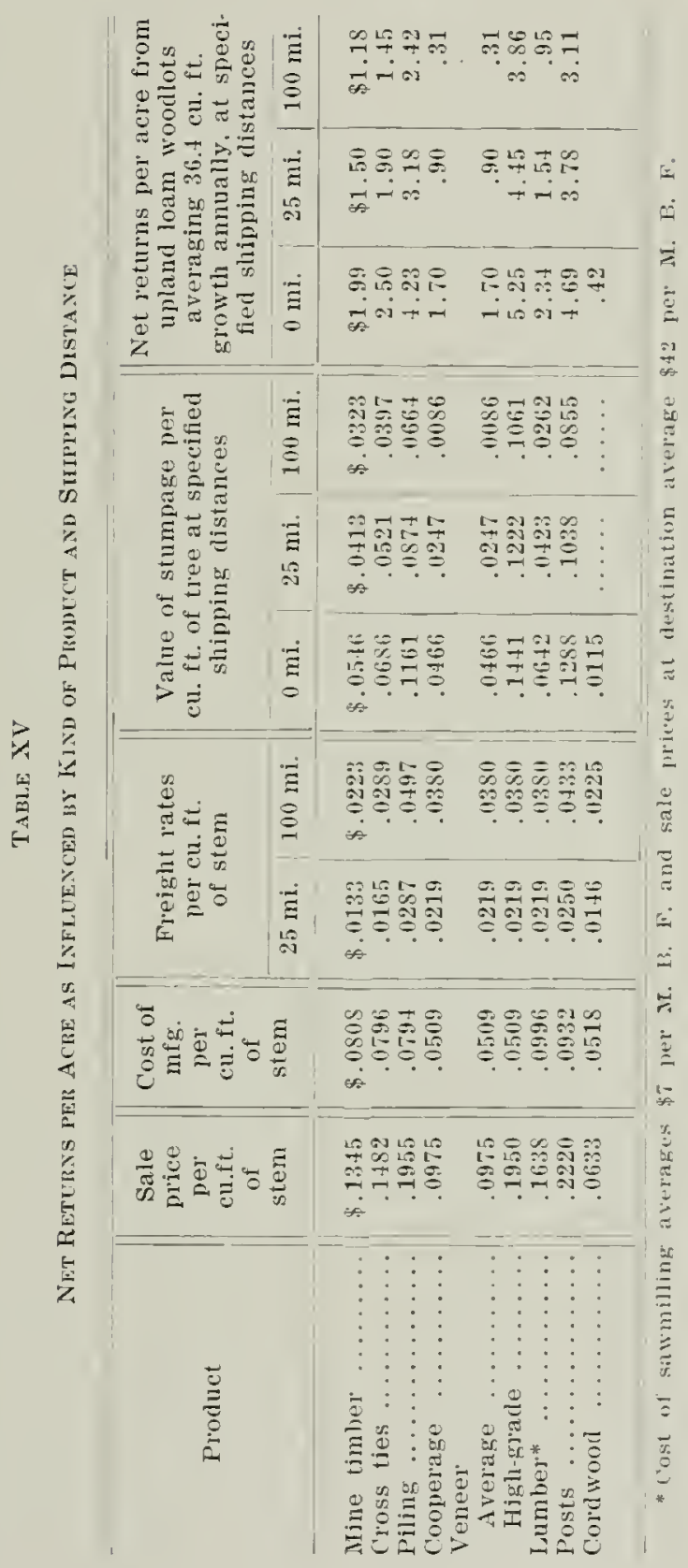


Thus Table XIV, in terms of cubic feet of produet, shows the margin left for profit and transportation of the different products in the following order: (1) high-grade veneer logs, (2) lumber, (3) posts, (4) ties, (5) piling, (6) mine timber, (7) cooperage and average veneer logs, and (8) cordwood. Table XV, containing the same data but also including the quantity utilized, rates the different products as follows: (1) high-grade veneer logs, (2) posts, (3) piling, (4) ties, (5) lnmber, (6) mine timber, (7) cooperage and average veneer logs, and (8) cordwood. This is the more accurate index of the relative average value of the different products from the prodncer's viewpoint.

High-grade veneer, posts and piling, are in general the most profitable products; the average net returns from woodlots yielding these are roughly twice as great as for those yielding ties, lumber, mine timber, or average veneer and cooperage logs, and ten times as great as those yielding cordwood. It is necessary to emphasize the fact that. while these are average statewide figures, yet the presence of local markets will modify these ratings, and the woodlot owner producing for the market must know the market conditions locally. For instance, cordwood sells for $\$ 8.00$ a cord in Chicago and $\$ 3.00$ in Johnson County. These are sale prices of $\$ 0.10$ and $\$ 0.0375$ per cubic foot, respectively. The cost of manufacturing is $\$ 0.0518$ per cubic foot. Woodlot owners near Chicago supplying this market find cordwood giving higher returns than either mine timbers or cooperage and average veneer logs, while those in Johnson County fail by $\$ 0.0143$ per cubic foot, or $\$ 1.14$ per cord. to get the average labor cost for producing it.

\section{SAWLOGS}

\section{Estimating standing timbor}

Logs for veneer, cooperage, and lumber are measured by the thousand board feet (M.B.F.). The amount of lumber in a standing tree is estinated by judging the number of logs which would be cut from the given tree and estimating the length and top diameter inside the bark of each log. The estimator requires a stick of lumberman's crayon (red) for marking trees, calipers for getting the diameter of the tree, a pencil, and a notebook. A convenient form for recording log lengths ind dianeters by species is shown on the following page.

Calipers may be purchased from a dealer in instruments of precision, or may be made from an ordinary carpenter's square by attaching an arm sliding along the beam and at right angles to it (see figure). If large timber is to be measured, the heam slould be 36 inches long; in second growtl, an 18- or 24-inch beam suffices. The sliding arm is made by cutting a half-inch strip about two inches wide, two inches longer than the short arm of the square. Next, get a strip of tongue-and-groove material six inches long and an inch and a half wide, shave off the tongue and mortise the first strip at right angles through the center of this 6-inch strip in such a way that when the beam of the carpenter's square is placed in the groove the mortised arm will be parallel 
to the fixed arm of the square. A brace, as shown in the figure, is necessary to strengthen the movable arm. When in use, the movable arm must be parallel to the fixed arm of the square.

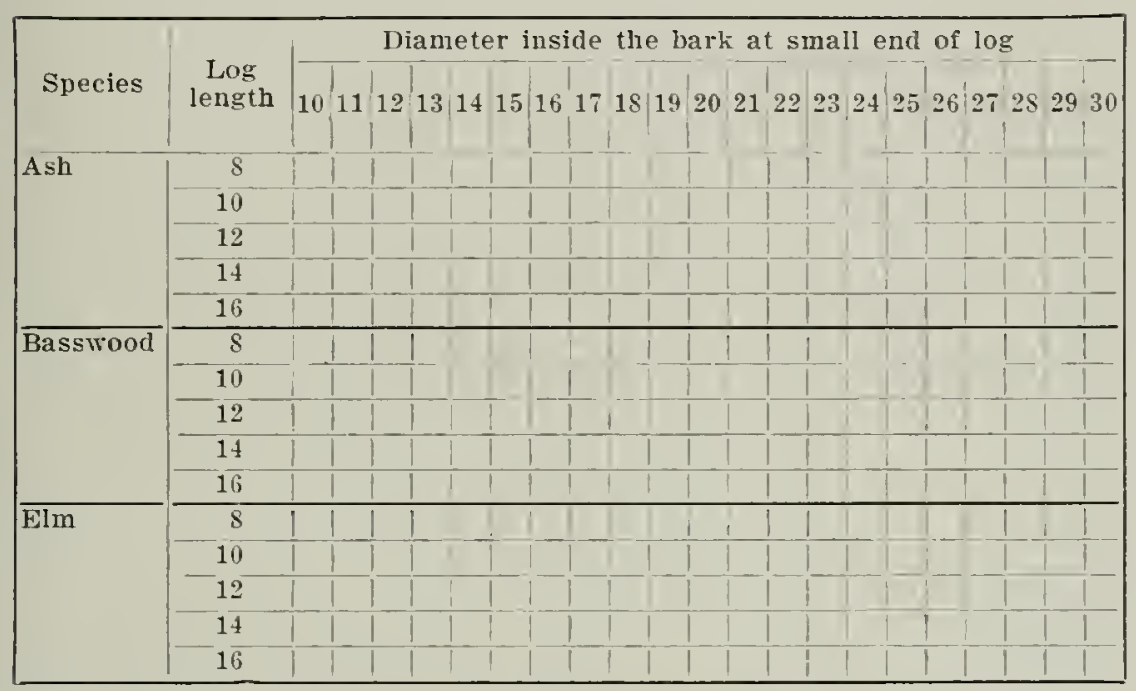

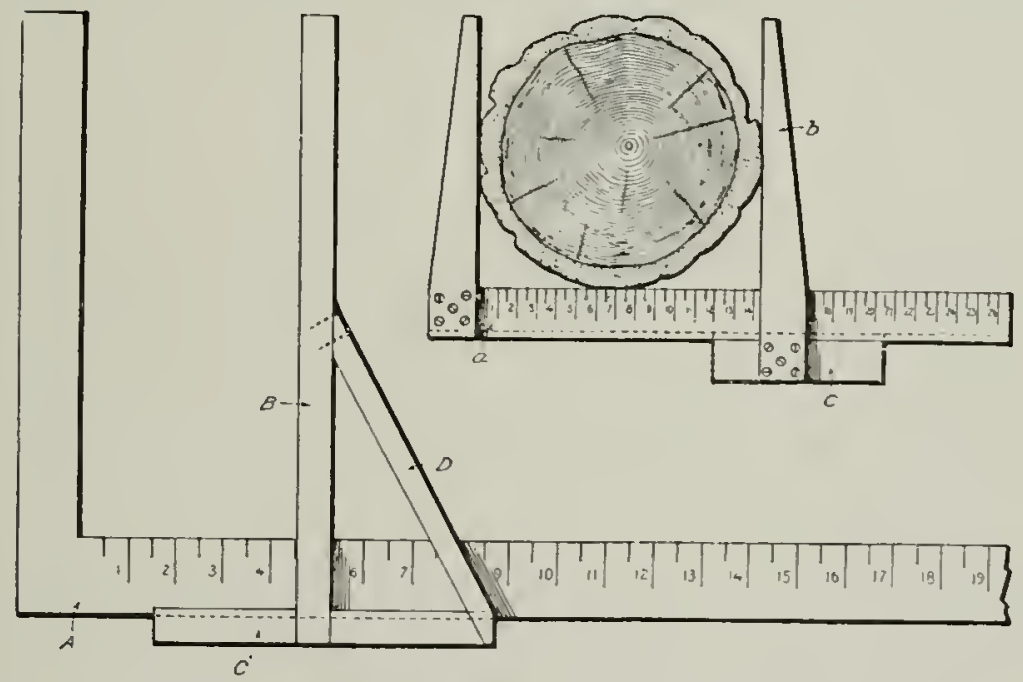

A simple homemade instrument, or calipers, for measuring the diameters of trees*

* Taken from L. S. Dent. Agr. Farmers' Bulletin No. 1210. 
The contents of large timber tracts are frequently estimated by measuring a percentage of a tract and applying the results to the entire tract. In ordinary woodlot work involving small areas, the contents of each tree should be estimated.

Uswally two work together. The estimator begins at a convenient side of the tract and estimates the trees in a strip 50 or 100 feet in width extending across the woodlot. He first measures the average diameter of the tree outside the bark at a point $4 \mathrm{~L} / 2$ feet from the ground. This is usually called the "diameter breast-high" (D. B. H.). This serves as a check and helps to estimate correctly the diameters of the logs into which he mentally divides the tree. He also marks the tree with the crayon at a given place where it will be visible as he works on the next strip. He then steps back to where he can get a clear view of the bole and lays off with his eye a $\log$ length $(8,10,12,14$, or 16 feet from the assumed stump) and estimates the diameter outside the bark at the upper end of the log. With a knowledge of average bark thiclinesses for trees of a given species and size, he mentally deducts the double bark thickness (D. B. T.), so as to get the diameter inside the bark (D. i. b.). See Table XVI for bark thickness of oaks. which can be used for most species.

He then calls the record to his companion; for example, "white oak, 14 feet, 18 inches." The tallyman places a single dot in the proper place on the form shown on page 83, to indicate a white oak log 14 feet long and 18 inches in cliameter inside the bark at the small end. Succeding logs are recorded by dots and lines until ten complete the figure, as follows:

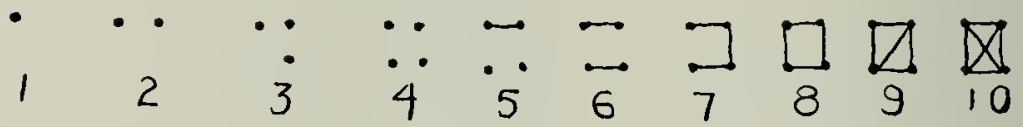

The estimator continues, mentally, to divide up the bole and estimate the $\log$ lengths and diameter of each $\log$ inside the barl at the small end, until he reaches a point in the crown where the material is unmerchantable. A ten-inch top is commonly taken as the minimum diameter for a log, but in large hardwoods the heavy limbs may prevent the economical use of logs of a diameter as small as this. Thus, in turn, all trees in the strip are estimated, and with succeeding strips the entire woodlot is covered.

The next step consists of computing the board-feet contained in the logs. For this, it is necessary to have a $\log$ rule. A log rule is a statement of the number of board feet contained in logs of different lengths and diameters. It may be marked on a stick or printed as a table.

Add up the total number of logs of each species having the same diameter and length, and multiply by the board-foot contents as shown for a $\log$ of this given length and top diameter inside the bark (D. i. b.). The summation for all logs gives the total for the woodlot. 
The many different log rules in use give quite different readings. The theory has been to construct a rule giving the number of board feet which could be sawed out of logs of a given region and under rather fixed marketing conditions. The early rules were made to fit conditions then in force, such as an abundance of large, defective trees and a demand for higl-quality material, and such rules do not give the quantity which is now cut from second-growth logs for a market ușing material formerly ummerchantable. Since they give a decided advantage to the buyer, these old rules have been retained in many instances. Thus, in Illinois practically all logs are scaled with the Doyle Rule. A comparison of the values for the Doyle and the International Rules, Table XVII, shows that the latter gives fully one-third greater amounts for 12-inch logs. In general, it may safely be said that there is sawed from ordinary-size timber 20 per cent more material than is scaled under the Doyle Rule.

If logs are to be sold, the buyer usually insists upon using the Doyle Rule: if the logs are to be sawed by the owner, a closer approximation of the yield can be secured by using the International Rule.

\section{TABLE XYI}

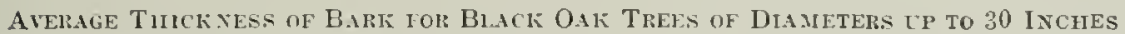

\begin{tabular}{|c|c|c|c|c|c|}
\hline $\begin{array}{c}\text { Diameter } \\
\text { breast-high } \\
\text { (D. B. H.) }\end{array}$ & $\begin{array}{l}\text { Double } \\
\text { bark } \\
\text { thickness } \\
\text { (D. B. T.) }\end{array}$ & D. B. H. & D. B. T. & D. B. H. & D. B. T. \\
\hline $\begin{array}{l}1 \\
2 \\
3 \\
4 \\
5 \\
6 \\
7 \\
S \\
9\end{array}$ & $\begin{array}{l}.1 \\
.1 \\
.2 \\
.3 \\
.4 \\
.5 \\
.6 \\
.7 \\
.5\end{array}$ & $\begin{array}{l}10 \\
11 \\
12 \\
13 \\
14 \\
15 \\
16 \\
17 \\
15 \\
19 \\
20\end{array}$ & $\begin{array}{r}.9 \\
1.0 \\
1.1 \\
1.2 \\
1.2 \\
1.3 \\
1.4 \\
1.5 \\
1.6 \\
1.6 \\
1.7\end{array}$ & $\begin{array}{l}21 \\
22 \\
23 \\
24 \\
25 \\
26 \\
27 \\
25 \\
29 \\
30\end{array}$ & $\begin{array}{l}1.8 \\
1.9 \\
2.0 \\
2.0 \\
2.1 \\
2.2 \\
2.3 \\
2.4 \\
2.5 \\
2.6\end{array}$ \\
\hline
\end{tabular}

\section{Scaling logs}

The process of scaling cut logs consists in measuring the average diameter inside the bark at the small enci, noting the log length, and looking up in a $\log$ rule the board-foot contents for a log of this diameter and length. The record can be kept in a form as shown on 1). 169. Where much scaling is done, a stick is used irom which can be read the contents of a $\log$ of specified length and diameter. W'hen the average diame- 
ter does not fall on the even inch, it is rounded off to the nearest inch class ; thus, 10.5 to 10 inches, 10.6 to 11 inches, etc. The values are for sound, straight logs, and if defects are present, a certain per cent is usually discounted. This rarely runs beyond 10 per cent, even for old-growth hardwood.

\section{Markets, Specifications, and Quotations}

Logs are valued according to species, size, and freedom from defects. Large, sound logs of a species suitable for high-grade veneer bring twice as much as those used for ordinary lumber, cooperage, or low-grade veneer such as goes into fruit containers and egg crating.

The leacling species used in high-grade veneers are black walnut, white oak, and red oak; and to a lesser extent tulip poplar, black cherry, and basswood are used. Sound logs of these species, with a D. i. b. of 16 inches and up, bring $\$ 50$ or more per M. B. F. at the points of consumption.

\section{TABLE XVII}

Board-Foot Contexts for Logs of Givex Dianeters and Lengths as Scaled by the INTernational RUle, (I) AND BY THE DOTLe RUle (D)

\begin{tabular}{|c|c|c|c|c|c|c|c|c|c|c|}
\hline \multirow{2}{*}{$\begin{array}{c}\text { Top } \\
\text { diameter } \\
\text { Inches }\end{array}$} & \multicolumn{10}{|c|}{ Length of the $\log$ in feet } \\
\hline & \multicolumn{2}{|c|}{8} & \multicolumn{2}{|c|}{10} & \multicolumn{2}{|c|}{12} & \multicolumn{2}{|c|}{14} & \multicolumn{2}{|c|}{16} \\
\hline & I & $\mathrm{D}$ & I & D & I & D & I & D & I & D \\
\hline 6 & 10 & 2.0 & 10 & 2.5 & 15 & 3.0 & 15 & 35 & 20 & 4.0 \\
\hline 7 & 10 & 4.5 & 15 & 5.0 & $\therefore 0$ & 7.0 & 25 & $s 0$ & 30 & 9.0 \\
\hline$\dot{8}$ & 15 & 8.0 & 20 & $10 . \mathrm{e}$ & 25 & 120 & 35 & 14.0 & 40 & 16.0 \\
\hline 9 & 20 & 12.0 & 30 & 16.0 & 35 & 19.0 & 45 & 22.0 & 50 & 25.0 \\
\hline 10 & 30 & 18.0 & 35 & 22.0 & 45 & 27.0 & 55 & 31.0 & 65 & 36.0 \\
\hline 11 & 35 & 24.0 & 45 & 310 & 55 & 370 & 70 & 43.0 & 80 & 49.0 \\
\hline 12 & 45 & 32.0 & 55 & 40.0 & 70 & 48.0 & $\$ 5$ & 560 & 95 & 64.0 \\
\hline 13 & 55 & 40.0 & 70 & 51.0 & รั & 61.0 & 100 & 71.0 & 115 & 81.0 \\
\hline 14 & 65 & 50.0 & so & 62.0 & 100 & 75.0 & 115 & $\$ 7.0$ & 135 & 100.0 \\
\hline 15 & 75 & 60.0 & 95 & 76.0 & 115 & 91.0 & 135 & 106.0 & 160 & 121.0 \\
\hline 16 & 85 & 72.0 & 110 & 90.0 & 130 & 108.0 & 155 & 126.0 & 180 & 144.0 \\
\hline 17 & 95 & $\$ 4.0$ & 125 & 106.0 & 150 & 127.0 & 180 & 148.0 & 205 & 169.0 \\
\hline 18 & 110 & 95.0 & 140 & 122.0 & 170 & 147.0 & 200 & 171.0 & 230 & 1960 \\
\hline 19 & 125 & 112.0 & 155 & 141.0 & 190 & 169.0 & 225 & 197.0 & 260 & 225.0 \\
\hline 20 & 140 & 128.0 & 175 & 160.0 & 210 & 1920 & 250 & 224.0 & 290 & 256.0 \\
\hline 21 & 155 & 141.0 & 195 & 181.0 & 235 & 217.0 & 280 & 253.0 & 320 & 289.0 \\
\hline 22 & 170 & 162.0 & 215 & 202.0 & 260 & $2 \pm 3.0$ & 305 & 283.0 & 355 & 3240 \\
\hline 23 & 185 & 180.0 & 235 & 226.0 & 285 & 271.0 & 335 & 316.0 & 390 & 361.0 \\
\hline 24 & 205 & 200.0 & 255 & 250.0 & 310 & 300.0 & 370 & 360.0 & 425 & 400.0 \\
\hline 25 & 220 & 220.0 & 280 & 276.0 & 340 & 331.0 & $\$ 00$ & 3860 & 460 & 441.0 \\
\hline 26 & 240 & 242.0 & 305 & 302.0 & 370 & 363.0 & 435 & 423.0 & 500 & 4840 \\
\hline 27 & 260 & 264.0 & 330 & 331.0 & 400 & 397.0 & 470 & 463.0 & 540 & 529.0 \\
\hline 28 & 280 & 288.0 & 355 & 360.0 & 430 & 432.0 & 510 & 504.0 & 5Sร̃ & 576.0 \\
\hline 29 & 305 & 312.0 & 385 & 391.0 & 465 & 469.0 & 545 & $5+7.0$ & 630 & 625.0 \\
\hline 30 & 325 & 338.0 & 410 & +22.0 & 495 & 5070 & 585 & 591.0 & 675 & 6760 \\
\hline 31 & 350 & 3640 & $4+0$ & 456.0 & 530 & $5+7.0$ & 625 & 638.0 & 720 & 729.0 \\
\hline 32 & 375 & 392.0 & 470 & 490.0 & 570 & 588.0 & 670 & 68.6 .0 & 770 & 784.0 \\
\hline 33 & +00 & +20.0 & 500 & 526.0 & 605 & 631.0 & 715 & 736.0 & 820 & $\$ 41.0$ \\
\hline 34 & 425 & 450.0 & 535 & 562.0 & 645 & 674.0 & 7.60 & 787.0 & 876 & 900.0 \\
\hline 35 & 450 & 480.0 & 565 & 601.0 & 686 & 721.0 & s05 & $S+1.0$ & 925 & 961.0 \\
\hline 36 & 475 & 512.0 & 600 & 610.0 & 725 & 7.68 .0 & $\$ 55$ & 896.0 & 980 & 1024.0 \\
\hline
\end{tabular}


Where local markets do not exist, it pays to market such logs at distant points. The prospective returns can be approxinated by getting specifications and quotations from buyers of the lind of logs in question. A list of dealers and consumers is given in appendix C. Get from the local freight agent the rates per 100 pounds on logs in carload lots to the markets in question. The number of pounds per M. B. F. of logs for various species is given in Table XTHII. The transportation cost per M. B. F. is found by multiplying the rate per 100 pounds by the number of hundred-weights shown in the table, and thus the best market may be determined. Full carload lots should be shipped to minimize the freight charge. Frequently it is advisable for several woodlot owners to cooperate in making carload shipments. From 1,000 to $:, 000 \mathrm{~B}$. F. (Doyle Rule) can be shipped per average car of 60,000 -pound capacity.

Logs should be cut in lengths of $8,10,12,14$, and 16 feet, and an allowance of from 3 to 6 inches should be mate for irregular saw-cut in working the tree "1], into logs. It is advisable to make long logs where possible, but the aim should be to get the most from the tree by making cuts so as to get the maximum amount of high-grale material.

Logs suitable for low-grade veneers used in the manufacture of containers for fruit, eggs, and vegetables, or for ordinary lumber, bring from $\$ 15$ to $\$ 30$ per M. B. F. at points of consumption. Specifications vary, but logs with a minimun diameter of 12 inclies are usually accepted. The manufacturers of fruit and vegetable containers use tulip poplar, sweet gum, tupelo gum, black gum, sycamore, cottonwood, willow, elm, cypress, birch, cucumber, hackberry, soft and hard maples. Egg crates are made chiefly from tupelo gum, sweet gum, and cottonwood. Local sawmills or wood-nsing industries in many regions offer a market for logs of practically all species listed above, as well as for ordinary oak and hickory. Prices paid usually range between $\$ 15$ and $\$ 30$ per 11 . B. F.

\section{LUMBER}

The efficient manufacture of lumber for special industries requires knowledge, experience, and capital not ordinarily at the command of the woodlot owner; consequently, he finds it difficult to manufacture to special sizes, grades, and quantities to meet the rerpirements of woodusing industries. The woodlot owner who decides to operate a sawmill will usually find a local narket for oak and hickory bridge plank and for linited amounts of mill-run rough lumber and dimension stock. This, with the tie market, usmally fumishes the chief outlet for such mills, but a better market can be developed for sound timber of the larger diameters. Narkets should be investigated even before the trees are cut, in order to determine the lengths and diameters required; and, if possible, contracts should be secured for the product before cutting a stick. 


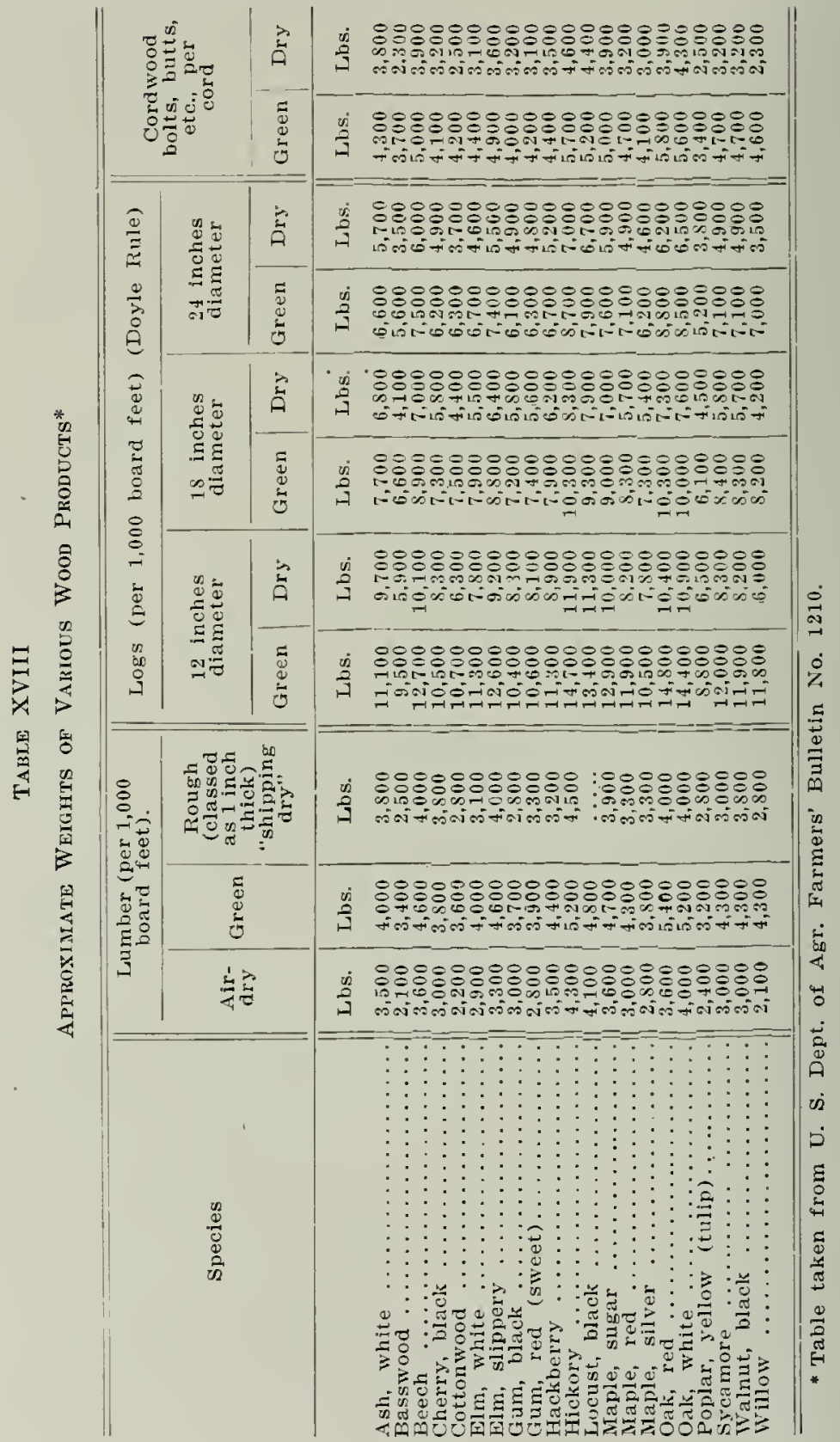


Grading hardwoods requires experience. The number of grades into which a given species is divided varies with different manufacturers, ranging from six to twenty or more grades for a single species. A description of the nuore standardized grades is given in grading rules which can be secured from the National Hardwood Lumber Association, McCornick Building, Clicago.

The weight of lumber per M. B. F. is given in Table XYIII. From 15 to 20 M. B. F. can be loaded to the car.

\section{rOSTS}

A great many posts are marketed locally to farmers or to retail lumber dealers. The steam ani electric lines also use large numbers and will furnish the specifications and puotations upon request. Some consmmers linit purchases to the few so-called durable woods; others use a greater variety. Ordinarily the specifications call for straight, sound, round posts having a top diameter ranging between 4 and 6 inches D. i. b. and a length of $i$ feet. cut square on both ends.

\section{TIES}

To estimate the ntmmber of ties in a tract of standing timber, there are required calipers, chalk, notebook, and pencil, as for estimating sawlogs. The following form is convenient.

\begin{tabular}{|c|c|c|c|c|}
\hline D.B.H. & $\begin{array}{l}\text { Black Oak } \\
\text { Height in feet }\end{array}$ & $\begin{array}{l}\text { White Oak } \\
\text { Height in leet }\end{array}$ & $\begin{array}{c}\text { Maple } \\
\text { Height in feet }\end{array}$ & $\begin{array}{l}\text { Elm } \\
\text { Height in feet }\end{array}$ \\
\hline & $\begin{array}{llll}50 & 60 & 70 & \mathrm{~S} 0\end{array}$ & $\begin{array}{llll}50 & 60 & 70 & 80\end{array}$ & $\begin{array}{llll}50 & 60 & 70 & 80\end{array}$ & $\begin{array}{llll}50 & 60 & 70 & S 0\end{array}$ \\
\hline 10 & & & & \\
\hline 11 & & & & \\
\hline 12 & & & & \\
\hline 13 & & & & \\
\hline 14 & & & & \\
\hline 15 & & & & \\
\hline 16 & & & & \\
\hline 17 & & & & \\
\hline 18 & & & & \\
\hline
\end{tabular}

When two work together, the estimator calipers each tree about $41 / 2$ feet from the ground, marks it, and estinates the total height, calling out, for instance, "white oak, $1 t$ inclies, to feet." His companion places a dot or line in the proper place on the form to record a white oak D. B. H. 14 inches, total height $: 0$ feet. The ustra] system of placing dots and lines as shown on p. 170, so that the closed figure records ten, is followed.

The total height can be estimated with the eye after a little practice, but at first the eye should be checked by measuring standing trees. A fairly accurate 
and simple method consists in using a straight stick having a length of about five feet. The estimator takes a position at a point he judges to be distant from the tree about the total height of the tree and on approximately the same level as the tree. He grasps the stick in the right hand and standing with his right side toward the tree holds the stick vertically at arm's length between his body and the tree and pivots it until the tip comes to his right eye. The stick is pivoted back again and held vertically at a full arm's length toward the tree, so that a line from the eye to the pivotal point of the stick cuts the base of the tree. He then advances or retreats until the tip of the stick and the tip of the tree are in line with his right eye, while the line from eye to hand cuts the base. The distance to the tree from the point where he now stands, equals the total height of the tree. With practice, this distance can be measured by pacing.

Heights should be recorded in the nearest height class, i. e., 55 feet in the 50 feet class, and 56 feet in the 60 feet class. When the field work is completed, the number and grades of ties can be approximated by reference to Table XIX.

\section{TABLE XIX}

Yield in Ties of Various Grades (No. 1-5) for Trees of Given Diameter AXD HETGHT

Based on studies of black oak

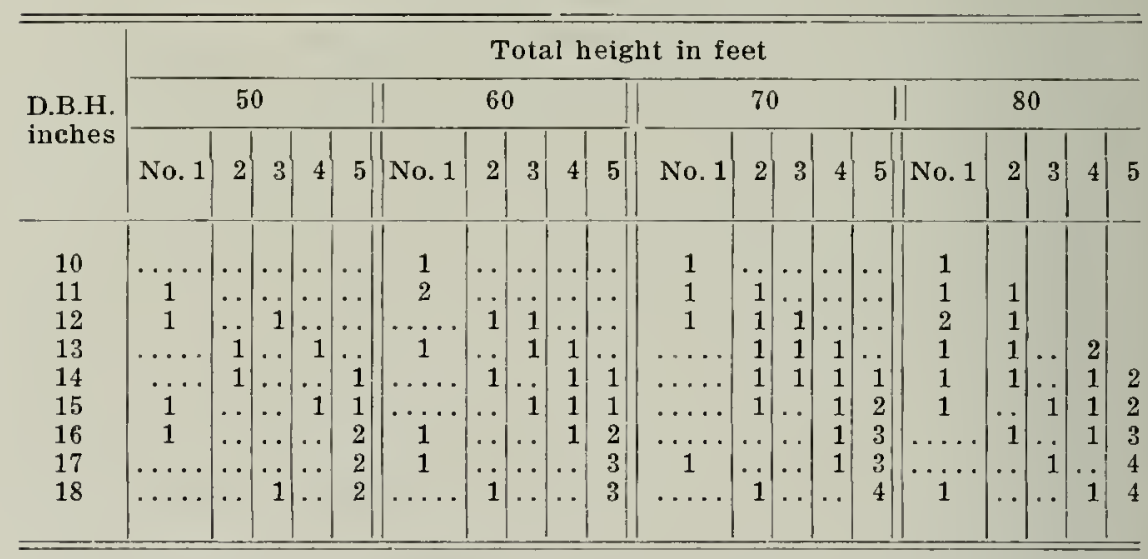

Ties are graded according to species and size. There is a slight variation in required length, some specifications calling for $8 \mathrm{r} / 2$ feet, others for 8 feet. Also, some roads use a wider range of species than others, or have special rules governing the cutting period and methods of delivery. For these reasons, it is advisable to get specifica- 
tions and quotations from the railroad where ties are to be marketed. This information can be secured through the local agent or by writing to the general purchasing agent. The quotations in Table $\mathrm{X}$ give a general idea of the relative values of the different species and grades.

TABLE XX

VAltes of TiEs (BASED ON AVerage QCotatioss)

\begin{tabular}{|c|c|c|c|c|c|c|c|}
\hline Grade & $\begin{array}{c}\text { Thick- } \\
\text { ness }\end{array}$ & Width & $\begin{array}{l}\text { "U A" } \\
\text { Black } \\
\text { locust, } \\
\text { White } \\
\text { oaks, } \\
\text { Black } \\
\text { walnut }\end{array}$ & $\begin{array}{c}\text { "U D" } \\
\text { Catalpa, } \\
\text { Red mul- } \\
\text { berry, } \\
\text { Sassafras }\end{array}$ & $\begin{array}{c}\text { "T A" } \\
\text { Ashes, } \\
\text { Hickories, } \\
\text { Honey } \\
\text { locust. } \\
\text { Red oalis }\end{array}$ & $\begin{array}{c}\text { "T C" } \\
\text { Beech, } \\
\text { Birch, } \\
\text { Cherry, } \\
\text { Hackberry, } \\
\text { Hard maple }\end{array}$ & $\begin{array}{l}\text { "T D" } \\
\text { Gums, } \\
\text { Soft } \\
\text { maples, } \\
\text { Sycamore, } \\
\text { White } \\
\text { walnut }\end{array}$ \\
\hline 1 & 6 & 6 & $\$ 0.55$ & $\$ 0.20$ & $\$ 0.45$ & $\$ 0.30$ & $\$ 0.20$ \\
\hline 2 & 6 & 7 & 0.75 & 0.30 & 0.65 & 0.50 & 0.40 \\
\hline 3 & $\left\{\begin{array}{l}7 \\
6\end{array}\right.$ & $\begin{array}{l}7 \\
\text { s }\end{array}$ & $\{1.00$ & 0.50 & 0.90 & 0.75 & 0.55 \\
\hline 4 & 7 & 8 & 1.25 & 0.65 & 1.15 & 1.00 & 0.65 \\
\hline 5 & $i$ & 9 & 1.35 & 0.75 & 1.25 & 1.10 & 0.75 \\
\hline
\end{tabular}

The steam railroads readily absorb grades 4 and $j$ but frequently local traction companies provicte a better market for the smaller ties.

\section{PILING}

Trees suitable for piling must be straight and must carry a long clear hole with relatively little taper. The woodtot owner who has tall straight trees ranging in diameter between 14 and 22 inches D. B. H. should investigate the possibilities of this market. Dealers in piling are given in the list in Appendix $C$. but in many cases the owner can market directly to consuners, such as railroad companies or contractors along the water front. Specifications vary, depending on the conditions under which the pile is to be used. The common sizes are 30 , 40 , and 50 feet in length with a minimum top diameter of 9,8 , and ; inches, respectively, and with a maximum butt diameter of 20 inches and a minimum of 12 inches. Prices depend not only upon the size but also upon the species, the more durable kinds, such as white oak, bringing a higher price. Species generally used are: black locust, white oaks, red gum, ash, beech, birch, cherry, elm, hickory, honey locust, naple, red oaks, and black gum. The approximate weights are given in Table XXI. 
To estimate the number of piles in a woodlot, there are required calipers, crayon, pencil, and notebook. A convenient form for recording material is given below:

\begin{tabular}{|c|c|c|c|c|c|c|c|}
\hline \multirow{2}{*}{ Species } & \multicolumn{7}{|c|}{ Length of pile in feet } \\
\cline { 2 - 4 } & 30 & 35 & 40 & 45 & 50 & $\mathbf{5 5}$ & 60 \\
\hline White oak... & & & & & & & \\
\hline Red oak..... & & & & & & \\
\hline Ash ........ & & & & & & & \\
\hline Elm ....... & & & & & & & \\
\hline
\end{tabular}

The estimator first determines if the tree has the required form, straightness, and size. Trees which have a D. B. H. between 14 and 22 inches are consmonly acceptable. He then marks the tree and estimates the maximum length which can be secured conforming with the top diameter requirements. The rule is to allow two inches for bark thickness. Consequently, for piling with a 7-inch top, a point in the stem must be selected which has a diameter of 9 incbes outside the bark. The estimator then jndges the distance from the stump to this point as the length of pile which can be cut. Some experience in estimating diameters and lengths is essential to accurate work. The tree is recorded by the dot-and-line system as for sawlogs.

\section{TABLE XXI}

Approximate Weights of Pllixg of Different Si/es, Green and Dry, for DIFFEREXT KINDS OF WOOD*

\begin{tabular}{|c|c|c|c|c|c|c|c|c|c|c|}
\hline \multirow{3}{*}{$\begin{array}{l}\text { Length } \\
\text { Feet }\end{array}$} & \multicolumn{2}{|c|}{ White Oak } & \multicolumn{2}{|c|}{ Black Oak } & \multicolumn{2}{|c|}{ Sugar Maple } & \multicolumn{2}{|c|}{ White Elm } & \multicolumn{2}{|c|}{ Black Gnm } \\
\hline & Green & $\begin{array}{l}\text { Air } \\
\text { dry }\end{array}$ & Greell & $\begin{array}{l}\text { Air } \\
\text { dry }\end{array}$ & Green & $\begin{array}{l}\text { Air } \\
\text { dry }\end{array}$ & Green & $\begin{array}{l}\text { Air } \\
\text { dry }\end{array}$ & Green & $\begin{array}{l}\text { Air } \\
\text { dry }\end{array}$ \\
\hline & \multicolumn{10}{|c|}{ Weight in pounds } \\
\hline 20 & 610 & 470 & 610 & 440 & 550 & 430 & 480 & 340 & 440 & 350 \\
\hline 25 & 770 & 590 & 770 & 550 & 690 & 530 & 600 & 430 & 550 & 450 \\
\hline 30 & 920 & 700 & 920 & 660 & 820 & 640 & 710 & 510 & 660 & 530 \\
\hline 35 & 1080 & 820 & 1080 & 770 & 960 & 750 & 840 & 600 & 770 & 620 \\
\hline 40 & 1580 & 1200 & 1590 & 1140 & 1410 & 1100 & 1230 & 880 & 1130 & 920 \\
\hline 45 & 1780 & 1360 & 1790 & 1280 & 1590 & 1240 & 1390 & 990 & 1270 & 1030 \\
\hline 50 & 1980 & 1500 & 1980 & 1420 & 1770 & 1370 & 1540 & 1090 & 1410 & 1140 \\
\hline
\end{tabular}

* From Farmers' Bulletin 1210, U. S. Dept. Agr., Washington, D. C. 


\section{MINE TIMBES}

The Illinois coal mines provide a market for large quantities of both rough and salvel wood. Wool in the round is used for jrops, legs, and hars. For ties. a face is hewed or sawed on one or more sides. For caps, inch boards alout one foot square are nued, and large quantities of sawed material are used in the louildings at the surface. The refuirements in sizes and lengths vary for the different seams minet. so that a list of specifications shonld be oltained from accessilsle maskets before cutting such imber. The latest coal report can be secured upon rerpuent at the Department of Mines and Minerals, Springheld, Illinois, which shows the location and tonnage produced from the operating mines. The list in appendix $C$ contains the addresses of most nine timber dealers and consumers.

Sticks, either split or round. such as are used for supporting the roof in temporary openings, are termed props. They are cut square at the ends from any hardwood, and the bark is left on. The minimum top diancer accepted nstlally varies between $t$ and $;$ inches. The mines in the I a Salle regrion require lengths from $3 \frac{1}{2}$ to $i$ feet: in Fulton Connty. 5 feet; in Sangamon County, 6 to $i$ feet; and in Milliamson Connty, $i / 2$ to 10 feet.

Legs are the upright posts used. together with the har across the top. to support the roof and walls in more permanent openings. For this work. white oak is ustally dennanded in lengths from s to 16 feet and in dianneters from 6 to $y$ inches.

Main-line, or motor, ties are usually oak from t to 6 feet long with a face of $t$ inches and a thickness of 5 inches. Roon ties are ustally lighter, having a face and dianeter an incl less. P'rices for props at the mine range from? to 3 cents per running foot, legs average + cents, and lars from $t$ to 10 cents. Motor ties bring about 25 cents each, and room ties from \& to 16 cents. Nine timlsers at these prices and under average costs of production (sce Table XIV. p). 1(i6) can be shipped up to 9.50 miles before all profit vanishes. Approximately 1200 mine ties constitute a carload, or from 800 to 1200 props, legs, or bars, depending upon the sizes. This market offers a very satisfactory outlet for the utilization of small materials such as usually come from thimnings or remain in the tops after a sawlog or milroad tie operation. The estinating of the amounts of mine timber per acre is complicated by the variety of products and specifications. No tables have been made to cover this material, but the general statenent can be made that ustually from one-fourth to one-half carload is cut per acre and that its requires an exceptionally well-stocked stand of thrifty polewood growth to produce a carload to the acre. 


\section{CORDWOOD}

Fuelwood and pulpwood are measured and marketed by the cord. Ordinarily the market price of cordwood does not justify any rail shipment. Local markets may be found among neighboring farmers, fuel dealers: bakers, and consumers of open-fireplace fuel. The meat packers offer a somewhat limited market for good hardwood at excellent prices, as they consume more than 5,000 cords annually. Charcoal plants in Johnson, Pulaski, Alexander, and Jersey counties furnish markets for cordwood located within short hauling distances. Limited amounts of pulpwood are also marketed from Illinois to Ohio.

The standard cord is a stack which measures 8 by + by + feet and contains 128 cubic feet. Ustrally the stack of green wood is piled 3 inches higher than 4 feet to allow for shrinkage in drying. An approximate estimate of the amount of cordwood in standing timber can be secured by calipering each tree in the plot and referring to Table XXII for the number of trees of each diameter required to yield one cord.

TABLE XXII

NuMber of Trees Required to Yield ONe Cord*

\begin{tabular}{c|r||c|c}
\hline $\begin{array}{c}\text { Diameter } \\
\text { of tree } \\
\text { breast-high }\end{array}$ & $\begin{array}{c}\text { Number of } \\
\text { trees }\end{array}$ & $\begin{array}{c}\text { Diameter } \\
\text { of tree } \\
\text { breast-high }\end{array}$ & $\begin{array}{c}\text { Number of } \\
\text { trees }\end{array}$ \\
\hline & 170 & 13 & \\
2 & 90 & 14 & 3.4 \\
3 & 50 & 15 & 3.0 \\
4 & 25 & 16 & 2.5 \\
5 & 17 & 17 & 2.0 \\
6 & 13 & 18 & 1.8 \\
7 & 9 & 19 & 1.5 \\
8 & 7 & 20 & 1.3 \\
9 & 6 & 21 & 1.2 \\
10 & 5 & 22 & 1.1 \\
11 & 4 & 23 & 1.0 \\
12 & & 24 & .9 \\
\hline
\end{tabular}
culture.

* Taken from Farmers' Bulletin No. 1210, United States Department of Agri-

The markets should be investigated before cutting. The requirements of the meat packers vary, but such species as oak and hickory in diameiers between $t$ and 8 inches are generally preferred. Quotations fall between $\$ 6$ and $\$ 16$ per cord for wood $\mathrm{f}$. o. b. destination. For wood pulp, the sticks must be $5 t$ inches in length, peeled, and of cottonwood, soft maple, or box elder. Sticks down to a 3-inch diameter are accepted, and the prices approximate $\$ 6.50$ per cord f. o. b. shipping point. Wood used in stoves and open fireplaces is usually cut into 16inch lengths and marketed locally by the short cord or by the pound, retailing in cities for about $\$ \%$ per short cord. A cord of air-dried hardwood weighs 4,000 pounds, and a box car holds from 15 to 18 cords. 


\section{Afrendir. A}

\section{Preseriatile Treatanent of Fexce Posts}

The practice of treating fence posts with preservatives permits the use of virtually all species. Posts which ordinarily would give service of from 3 to 10 years can be treated so as to serve 20 years or more, so that species which have rapid growth rates and immunity from destructive insect attacks may be chosen for post production. Cottonwood, silver maple, willow, and honey locust are very satisfactory post trees. Cottonwood will produce posts in five years on good bottomland soils, is a very suitable tree on upland prairie loams, makes growth acceptable for posts on upland sands, but does not make acceptable growth on hardpan soils. The cost of treatment increases with increase in the size of the post, and for this reason posts having a dianeter under five inches are preferable to larger ones. Split posts when properly treated have practically the same durability as round posts. The cost of treatment runs up to 20 cents per post.

Posts with a high percentage of sapwood. such as usually require preservative treatment, often check if cut in the summer, and for this reason it is preferable, although not essential, to cut them in the dormant season. They should be peeled, and it is important to carefully remove the inner as well as the outer bark. The posts should then be piled off the ground in such a manner as to give free air circulation. They should be left in this condition two or three months in order to season properly hefore being treated.

The application of preservatives to the surface is not effective; hence. the slight increase in durability secured by brush or dipping treatments of tars and paints does not warrant the expense. An effective treatment, practical for farm use, is called the onen-tank process.

The simplest equipment for this process is a single tank set over a fire pit. The tank should be deep enough to insure submergence of fully half the length of the post at a dipping. A large oil drum* has a capacity of 25 posts per day. Care should be exercised in selecting a location away from huildings. The pit should be partly below ground level in order to lieep the top of the tank as low as possible. It can be walled in with brich, hollow tile, or rock, leaving an aperture for the flue and an opening to stoke the fire. In a temporary

* A tank with a s-foot diameter and t-fool depth made from 20 gauge iron with angle iron reinforcements, all joints riveted and rivet holes soldered. 
set-up where cement is not used, earth should be banked about the outside of the foundation. Three or four lengths of ordinary stove pipe can be used for a flue. Four iron bars are laid across the top of the toundation as a support for the tank. Earth placed against the sides of the tank serves to hold the heat in the pit, while the opening in front and the flue furnish ample draft. Enough coal-tar creosote is placed in the tank so that with its charge of posts the tank is full. The creosote is heated to a temperature of at least $180^{\circ} \mathrm{F}$. but should not he heated above $200^{\circ} \mathrm{F}$., as there is then a loss of the oils through evaporation. The posts are placed in position with the larger end dowll, with at least 3 to $3 \frac{1}{2}$ feet submerged, and held in creosote at the above temperatures, as follows: Soft maple and cottonwood, 2 hours; willow, 4 hours. The butt treatment of yellow poplar aud sycamore requires about the same time as cottonwood, while fully 6 hours are required for good impregnation of white ash, elm, hackberry, hickory, hard maple, and black oak. The preservative should go into the wood at least a lialf-inch. The amount of creosote absorbed averages half a gallon per post. Keep the creosote at a uniform level by adding more as posts absorb it. The posts should be left in the tauk until the creosote cools, and the creosote should be kept at a uniform depth for this time also.

The tops should next be treated by inverting the posts so that all wood not previously reached is submerged, and leaving them in the tank while the creosote is being heated up to $180^{\circ} \mathrm{F}$. The posts should then be put in open piles. The excess creosote in the tank can be put back into a barrel and stored until needed again. It is important, in setting posts thus treated, that the top line of the butt treatment should be at least 6 inches above the ground line.

Where the number of posts to be treated justifies the installation of more elaborate equipment, a second tank* of cold creosote is used. After the butt treatment in the hot creosote, the posts are immediately transferred to the tank of cold creosote. These are beld in the cold creosote until the posts are thoroughly cooled, and by this process the preservative is drawn into the heated portion of the butt. The coating whicb the top receives is enough to safeguard it against ordinary decay.

* The best type of tank for the cold creosote is a $2 \frac{1}{2} \times 2 \frac{1}{2} \times 8$ foot stock tank. It should have ample capacity to hold completely submerged all posts from the hot tank. 


\section{Atpendi.. $B$}

Concerno Denhing in Tree Seedlixis and Transplants**

D. Hill Nursery, Dundee, Illinois.

Onarga Nursery Company, Onarga, Illinois.

Naperville Nurscries. Naperville, Illinois.

Betsie River Nursery, Thompsonville. Michigan.

Northeastern Nursery Company, Cheshire, Connecticut.

F. W. Kelsey Nursery Co., io Church Street, New York City.

Evergreen Nursery Company, Sturgeon Bay, Wisconsin.

Forest Nursery Co., Inc., Aledinnville, Tennessee.

\section{Tree SEed DElleks"}

T. Meehnn Sons, Dresher, Penneylvania.

Thomas J. Lane, Dresher, Pennsylyania.

Conyers B. Fleu, Ir., Germantown, Pennsythania.

Otto Katzenstem, i Cone St., Atlanta, Georgia.

J. M. Thorburn, : Be Barclay Avenue, New York City.

The Barteldes Seed Co., Lawrence, Kansas.

I. E. Williams, Exeter, New Hampshire.

The American Forestry Co. P'emtine. Wisconsin.

Frank N. Graass, Sturgeon Bay, Wisconsin.

* These lists have ben carefully mupared for the convenience of woodfot owners, but the State Natural History. Survey does not vouch for their completeness nor guarantee the responsibility of the concerns here named. 


\section{Appendix $C$ \\ List of CONSUMers and Dealers*}

\section{ADAMIS COUNTY}

Lumber

Electric Wheel Co., Quincy. Buy graded oak and hickory cut to special sizes.

Collins Plow Co., Quincy. Buy graded elm and oak.

Henry Knapsheide Wagon Co., Quincy. Buy graded oak.

Quincy Show Case Works, Quincy. Buy black walnut, oak and rough local lumber.

Alexander County

Logs

Peterson-Miller Box Co., Cairo. Buy cottonwood, sycamore, willow, and red gum.

Singer Mfg. Co., C'airo. Buy black walnut, white and red oak, and red Lumber gum.

Vehicle Supply Co., Cairo. Buy oak and hickory cut to special sizes. Piling

Solomon Tie \& Timber Co., Cairo. Buy ties.

Solomon Tie \& Timber Co., Cairo. Buy piling.

Cordwood

Solonon Tie \& Timber Co., Cairo. Buy cordwood at Tamms.

Alabama Charcoal Co., Kansas City, Mo. Buy cordwood at Cache and Sxwodust Olive Branch.

E. Bucher Packing Co., Cairo. Buy hardwood sawdust. standing timber

Solomon Tie \& Timber Co., Cairo.

Boone CounTy

Logs

National Sewing Machine Co., Belvidere. Buy walnut.

Buresu COUXTY

Mine timbers

Spring Valley Coal Co., No. 3. Springvalley.

Saint Paul Coal Co., No. 2, Cherry.

\section{Christian County}

Minc timbers

Penwell Coal Mining Co., Pana.

Springside Coal Co., Pana.

Pana Coal Co., No. 1 and 2, Pana.

Peabody Coal Co., No. 7, Kiucaid.

Peabody Coal Co., No. 8, Tovey.

Peabody Coal Co., No. 9, Taylorville.

Peabody Coal Co., No. 21, Stonington.

* The Natural History Survey does not vouch for the completeness of this list nor guarantee the responsibility of the concerns named here. 


\section{CLINTON CotNTY}

Mine timbers

Breese-Trenton Mining Co., Beckemeyer.

WT. W. Smith, lieyesport.

\section{Cook Cocivis}

Logs

R. S. Bacon Veneer Co., 213 X. Ann st., Clicago. Buy walnut.

Adolph Sturm Co., 542-44 W. Washington St., Chicago. Buy dogwood Lumber and persimmon.

Pullman Car \& Mfg. Corp., Pullman. Buy graded car stock.

Yellow Cab Mfg. Co., Clicago. Buy graded ash.

Marsh \& Truman Lumber Co., 332 S. Mich. Ave., Chicago. Buy car stock crossing plank, etc.

L. D. Leach \& Co.. $5 \mathrm{X}$. Wabash. Chicago. Buy locally sawed lumber.

Chicago Mill \& Lumber Co., Conway Bldg., Chicago. Buy locally sawed lumber.

Frank B. Stone. Maller's Bldg., Chicago. Buy local lumber.

Anguera Lumber \& Tie Co., $111 \mathrm{~W}$. Washington, Chicago. Buy local lumber.

Posts. Ties, and Pilin!

L. D. Leach \& Co., 5 . . Wabash. Chicago. Buy piling and ties.

Chicago Mill \& Lumber Co., Conway Bldg., Chicago. Buy piling poles and posts.

W. W. and A. J. Schultz, 1235 Colony Bldg., 37 W. Van Buren St., Chicago. Buy piling.

Ozark Timber Co.. $\$ 33 \mathrm{~W}$. Mashington. Chicago. Buy ties.

Frank B. Stone, Maller's Bldg., Chicago. Buy piling and ties.

Anguera Lumber \& Tie Co., $111 \mathrm{~K}$. Mashington, Chicago. Buy ties.

Bay, DeNouquet Co.. So E. Jackson Bldr.. Chicago, Buy ties.

W. B. Crane Co., 2:nd and Sangamon St.., Chicago. Buy ties.

Marsh \& Truman Lumber Co., 332 S. Michigan Ave., Chicago. Buy ties.

Lake Superior Piling Co., 22nd and Mlorgan St., Chicago. Buy piling.

C. B. \& Q. R. R. Co.. Burlington Bldg., Chicago. Buy ties aud piling.

C. Ml. \& St. Paul Ry., Exchange Bldg. Chicago Buy" piling, ties, and posts.

Cordurood anel sacdust

Swift \& Co., L'nion Stock Yards. Chicago. Buy cordwood and sawdust. Armold Bros., Inc., 660 W. Randolph St., Chicago. Buy hardwood sawdust.

Jourdan Packing Co., Chicago. Buy hardwood sawdust

Cudahy Packiug Co., 111 W. Monlee St.. Chicago. Buy oak hickory cordwood and sawdust.

Omaha Packing Co., 2320 W. Halsted St., Chicago. Buy oak hickory cordwood and sawdust.

Roherts \& Oaks, 45th and Racine Ave.. Chicago. Buy oak hiçory cordwood and sawdust.

Hately Bros. Co.. 3ith and Ha!sted Sts.. Chicago. Birch, maple, oak, hickory corảwood and sawdust.

William Dariess Co., Inc.. ['nion Stock Yards. Chicago. Birch, mavle. oak, lickory cordwood and sawdust.

Armcur \& MIorris, Lnion Stoch Yards, Chicago. Oak wood, oak and maple sawdust.

Libby, IlcNeil \& Libby, [nion Stock Yards, Chicago. Oak and lickory wood and sawdust.

Beiersdorf \& Bros., 932 W. 3Sth Place, Chicago. Buy oak. hickory, wood and samilust. 
Cook Countr-(Continued)

Covey Durham Co., 431 S. Dearboru St., Chicago. Buy cordwood and standing timber.

lllinois Fuel Co., 39 S. LaSalle St., Chicago. Fuelwood retailer.

Northern Wood Fuel Co., 310 S. Mich. Ave., Chicago. Fuelwood retailer.

W. A. Davis Hardwood Co., 122 S. Mich. Ave., Chicago. Fuelwood retailer.

Buesing Homan Coal Co., 2151 N. Lincoln St., Chicago. Fuelwood retailer.

Chicago Wood \& Coal Co., 4900 W. Chicago Ave., Chicago. Fuelwood retailer.

Wilson \& Co., 4100 S. Ashland Ave., Chicago. Naple and hichory wood and sawdust.

Chicago Butchers Packing Co., 216-222 N. Peoria St., Chicago. Buy maple and hickory wood and sawdust.

G. H. Hammond Co., Union Stock Yards, Chicago. Buy elm, maple, oak, hickory wood and sawdust.

Reliable Packing Co., 1446-1452 W. 47th St., Chicago. Buy hardwood sawdust.

Miscellancous

Hartwell Handle Co., 146th and Lincoln Ave., Harvey. Use sapling hickory.

H. R. Mosnat, 10, 910 Prospect Ave., MIorgan Park, Chicago. Buy walnut kernels.

DEWITT Cousty

Cordwood

Clinton Coal Co., Clinton.

C. E. Crang, Clintols.

Eugan County

Logs

T. A. Foley, Paris. Buys black walnut, cherry and high grade logs.

Lumber

Cummings Car \& Coach Co., Paris. Buys car stock.

EFFingham County

Lumber

John Boos, Effingham. Buys specially sawed soft maple.

Nine timbers

C. E. Hershey \& Co., Effingham.

FayetTe Covnty

Hine timbers

Sholmier Timber Co., Vandalia.

Franklin County

Mine timbers

Valier Coal Co., Valier.

Franklin County Coal Co. No. 7, Royalton.

Franklin County Coal Co., No. 5, Herrin.

Franklin County Miuing Co., Benton.

Old Ben Coal Corp. Nos. 8, 9, 19, West Frankfort.

Old Ben Coal Corp. Nos. 10, 11, 12, Christopher.

old Ben Coal Corp. No. 14, Buckner.

old Ben Coal Corp. No. 15, Ezra.

old Ben Coal Corp. No. 16, Sesser.

C. W. \& F. Orient No. 2, West Frankfort.

C. W. \& F. Orient No. 1, Orient.

Peabody Coal Co., No. 18, West Frankfort.

Bell \& Zoller Mining Co., No. 2, Zeigler. 
Filtox Cotaty

vine timbers

Canton Coal Co., Canton.

Bucklieart Coal Co., Canton.

Rawal Coal Co., Canton.

Iurphy \& Loftus, Canton.

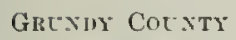

Nine timbers

Wilmington Star M. Co., Coal City.

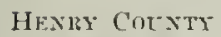

vine timbers

Shuler Coal Co., Alpha.

JACKsn Cotxit

Logs

Merchants Basket \& Box Co.. Grand Tower. Buy elm, gum, etc., logs Tics $16^{\prime \prime}$ and up.

Ayer \& Lord Tie Co., Carbondale.

Mine timbers

DeSoto-Peacock Coal Co., DeSoto.

Harsha \& Floyd. Vergennes.

Rector Bros., Hurphysloro.

H. M. Sellers, s00 S. Forest St., Carbondale.

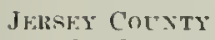

Corduood

Equitalle Powder Mfg. Co., E. Alton. L'se bottomland and hardwoods in charcoal plant at Grafton.

Johision Cot'xty

Corduood

Berger Bros., 1176 Cherry Ave., Chicago. Charcoal plant at Bellinap.

\section{FAXE COTNT}

Logs Lumber

Westgate Walnut Co., Aurora. Buy black walnut.

Appleton Mfg. Co.. Batavia. Buy graded oak.

\section{L.ISALE: COT'xTY}

Lumber Ties

King \& Hamilton Co., Ottawa. Graded oak.

Nortlwestern Timber Co.. Mendota. Also buy standing timber. vine timbers

LaSalle County Carbon Coal Co.. ['nion.

\section{ICLF.A. COUNTY}

Logs Lumber

J. O. Wheadon, Bloomington. Buys walnut logs, standing timber, ties, lumber, mine props and cordwood.

Paul O. Moratz. Bloomiugton. Buys log run oak and hard maple lumber.

Macon Cotxtr

Cordivood

Danzeisen Packing Co., Decatur. Buy oak hickory wood. 
MaCoupin County

Hine timbers

Madison Coal Corp. No. 5, Mt. Olive.

Madisox Countr

Lumber

American Car Foundry Co., Madison. Buy car stock.

Illinois Glass Co., Alton. Buy cottonwood lumber.

\section{MaRION COUNTY}

Mine timbers

L. S. Gray, Centralia.

\section{MARSIIALL COUNTY}

Mine timbers

F. A. Barr, Lacon.

\section{MASON COUNTY}

Lumber

Havana Metal Wheel Co., Havana. Buy graded oak, ash, hickory.

\section{Massac Countr}

Logs

E. C. Artman Lumber Co., Metropolis.

Ties

Roberts Liggett Co., Metropolis.

E. C. Artman Lumber Co., Netropolis.

Bennett-Field Tie Co., Tie plant at Brookport.

Mine timbers

Bennett-Field Tie Co., Brookport (main office 1406 Fisher Bldg., Chicago).

Montgonery County

Mine timbers

Hillsboro Coal Co., Hillshoro.

Morgan CoUNTY

Cordwood and sawdust

Powers Begg \& Co., Packers, Jacksonville. Buy hardwood and sawdust.

Walton \& Co., Jacksonville, cordwood retailers.

Rogerson \& Co., Jacksonville, cordwood retailers.

J. A. Paschall, Jacksonville, cordwood retailers.

\section{Peoria Countr}

Logs

National Cooperage \& Woodenware Co., Peoria. Buy red and white oak.

Moschell \& Whitfield, Marshall Block, Pekin. Buy black cherry and walnut logs.

Iine timbers

Crescent Coal Co., No. 6, Peoria.

Neusau Bros. Coal Co., Glasford.

Crescent Coal Co., No. 1, Peoria.

Hanna City Mining Co., Hanna City.

Bartonville Coal Co., Peoria.

Cordwood and sawdust

Wilson Provision Co., Peoria. Buy maple, oak, hickory wood and sawdust.

Godel \& Sons, Peoria. Buy oak, hickory wood. 


\section{Penky Couxty}

Mine timbers

Crear Clinch Coal Co., DuQuoin.

Willis Coal \& Mining Co., No. 7. Sparta.

\section{Puiaski Colity}

Logs

O. L. Bartlett, Mound City. Buys elm, gum, hackberry, maple. ash. and sycamore.

Geo. L. Kannapell, Mound City Veneer Nlils. Buys tulip and gum.

Portsmouth Veneer \& Panel Co., Mound City. Buy oak, poplar and gum.

Inman Veneer \& Panel Co., Mound City. Buy poplar, gum, and oak.

Main Bros. Box \& Lumber Co., Farnak. Buy sottwood logs locally. Corduoorl

B. E. Moses. Perks.

J. E. Black Charcoal Co., Ullin.

\section{Putyan Cotity}

Hine timbers

Barney Ernst, Granville.

A. Hecht, Magnolia.

\section{RAXDOLPII COI'XTY}

line timbers

Madison Coal Corp., Tilden.

\section{Rock Islaxp Cotxty}

Lumber

Strombek-Becker Mlg. Co., Box 74, Moline. Buy locally sawed basswood.

St. Chate Cotsty

Logs

W. L. Fletcher, I1l. Walnut Co., E. St. Louis. Buys walnut.

Iine timbers

B. B. Coal Co., Belleville.

Prairie Coal Co., O'Fallon.

Mulberry Hill Coal Co., Freeburg.

Southern Coal, Colke \& M. Co.. Nos. 1, 6. 7, S. Belleville.

Aluminum Ore Co., E. St. Louis.

Groom Coal Co., Belleville.

Lou Nash Coal Co., Freeburg.

Corduood and sawdust

Armour and Co., E. St. Louis. Buy hickory wood, hardwood sawdust.

Swift and Co., E. St. Louis. Buy hickory wood, hardwood sawdust.

SAINE COUXTY

Mine timbers

Dodds Coal Co.. Carriers Mills.

Harrisburg Coal M. Co. B. B., Harrisburg.

Saximox Corxty

line timbers

Madison Coal Corp., Divernon.

West End Coal Co., Springfield.

Sangamon Coal Co., No. 2. Spriugfield.

New Staunton Coal Co., Livingston.

C. W. \& F. Coal Co., No. 1, Thayer. 


\section{Saxgudo. Couxty-(Continued)}

Peabody Coal Co., No. 6, Sherman.

Peabody Coal Co., No. 51, Auburn.

Peabody Coal Co., No. 52, Riverton.

Peabody Coal Co., No. 53, Springfield.

Peabody Coal Co., No. 54, Auburn.

Peabody Coal Co., No. 55, Springfield.

Castleman Bros. Timber Co., 401 Ridgley, Springfield. Buys ties, stand. ing timber, mine timber.

Standard Tie \& Timber Co.. Reisch Bldg., Springfield.

\section{SIIELBY COUNTY}

Mine timbers

Moweaqua Coal M. Co., Moweaqua.

J. J. Patterson, Trowbridge, R. R. 1

\section{TAZEWELL County}

Nine timbers

Groveland Coal M. Co., Pekin.

Ubben Coal Co., Pekin.

\section{Lxiox County}

Logs

H. A. DuBois, Cobden. Buys gum, sycamore, maple, poplar, cottonwood, willow, elm, and hackberry.

Julius Rendelman, Alto Pass. Buys poplar, gum, beech, sycamore, etc.

Ed. Karraker, Jonesboro. Buys poplar, gum, beech, sycamore, etc.

C. M. Sampson, Jonesboro. Buys oak and poplar veneer logs.

R. L. Lawrence, Cobden. Buys basket veneer logs.

Dongola Box Factory, Dongola. Buy softwood and oak logs.

Fruit Growers Package Co., Jonesboro. Buy maple, beech, sycamore, etc.

C. M. Sampson, Jonesboro.

\section{Vermilion Colite}

Logs

Pierson-Hollowell Walnut Co., 520 Section St., Danville. Buy walnut. Mine timbers

Peabody Coal Co., No. 24, Danville.

\section{WARREN CounTY}

Lumber

Western Stoneware Co., Monmouth. Buy rough local lumber.

Mine timbers

Dennis Howard, Monmouth.

\section{WasingGtor County}

Logs

J. J. Pool, Richview. Buy cooperage stock.

\section{WiIte CounTY}

Mine timbers

C. A. Fitch, Norris City.

\section{WHITESIDE COUNTY}

Logs

Illinois Refrigerator Co., Morrison. Buy ash, basswood, elm, maple $\log$ s and lumber. 
Will, Colsti

Logs

Federal Match Corp., Joliet. Basswood logs.

WILLAMSOX CoUxt

Mine timbers

Sincerity Coal Co., Marion.

Crear Clinch Coal Co., Herrin.

Sincerity Coal Co., Carterville.

Crear Clinch Coal Co., Johnson City.

St. Lonis Coal \& Irom Co., No. 1, Johnson City.

Consolidated Coal Co., No. 7, Herrin.

Freeman Coal M. Co., Herrin.

Old Ben Coal Corp. No. 18, Johnson City.

old Ben Coal Corp. No. 20. Herrin.

C. W. \& F. Mining Co., Mine A. Herrin.

Peabody Coal Co., No. 3, Mlarion.

Southerll Timber Co., Marion.

Wincenato Coñt

$\log s$

Litton Veneer Co., Rockforl. Buy walnut, basswood, and elm.

1llinois Veneer Co., Rockford. Buy walnut, basswoor, and elm. Lumber

Rockford Furniture Co., Rockford. Buy walnut and basswood.

lllinois Sewing Machine Co., Rockford. Buy walnut and basswood.

Old Colony Chair Co., Rockford. Buy walnut.

Continental Desk Co., Rockford. Buy cedar.

Rockford Eagle Furniture Co., lnc., Rockford. Buy red cedar.

Rockford Reed \& Fibre Co., Rockfori. Buy rock elm.

lockford Cedar Furniture Co., Rockford. Buy red cedar.

WOOHFORD ConTtr

Mine timbers

Banta Bros., Lowpoint.

Rudolph Durst., Metamora. 


\section{Appendi.x $D$}

\section{United States Departaent of Agriculture}

\section{Publications Relating to Woodlot Management and Ornamental Tree Culture}

For the following publications, address the U. S. Department of Agriculture, Washington, D. C.

Trees for shade and ornament

Planting and care of street trees. (Farmers' Bulletin 1209) 5 cents.

Street trees-kinds, description, culture, and care. (Department Bulletin 816) 15 cents.

Tree Surgery. (Farmers' Bulletin 1178) 5 cents.

Trees for town and city streets. (Farmers' Bulletin 1208) 5 cents. Planting the roadside. (Farmers' Bulletin 1481).

Trees for roadside planting. (Farmers' Bulletin 1482).

Beautifying the farmstead. (Farmers' Bulletin 108i).

Insects injurious to deciduous shade trees and their control. (Farmers' Bulletin 1169) 15 cents.

Trees for wood production

Cottonwood in the Mississippi Valley. (Department Bulletin 24) 10 cents.

Protection from the locust borer. (Department Bulletin $78 \%$ ) 5 cents.

White pine under forest management. (Department Bulletin 13) 15 cents.

Black walnut for timber and nuts. (Farmers' Bulletin 1392) 5 cents.

Black walnut, its growth and nanagement. (Department Bulletin 933) 20 cents.

Selling black walnut timber. (Farmers'Bulletin 1459.)

Basket willow culture. (Farmers' Bulletin 622) 5 cents.

Basket willow, with chapter on insects injurious to basket willow. (Forest Bulletin 46) 15 cents.

Farm forestry

Care and improvement of the farm woods. (Farmers' Bulletin $117 \%) 5$ cents.

Cooperative marketing of woodland products. (Farmers' Bulletin 1100) 5 cents. 
Forestry and farm incone. (Farmers Bulletin 111i) j cents.

Forestry lessons on home woodlands. (Department Bulletin 863) 15 cents.

Measuring and marketing farm timber. (Farmers' Bulletin 1210) 5 cents.

Preserving treatment of farm timbers. (Farmers' Bulletin it4) 5 cents.

Machinery for cutting firewood. (Farmers' Bulletin 10:3) 5 cents. Use of wood for fuel. (Department Bulletin i53) 10 cents.

Wasteland and wasted land on farms. (Farmers' Bulletin it5). Second-growth hardwoods in Comecticut. (Forest Service Bulletin 96$) 15$ cents.

Growing and planting hardwood scedlings on the farm. (Farmers' Bulletin 112:3).

Growing and planting coniferons trees on the farm. (Farmers' Bulletin 1+53).

\section{Appondi.r $E$}

\section{Illinois State Nitural Historl Survey \\ I'UBLICATIONS ON Forestry}

Sent free upon request

Hall, R. C., and Ingall, O. D.

1911. Forest conditions in Illinois. Vol. 1X, Art. $t$.

Forbes, S. A.

1920. Concenning a forestry survey and a forester for Illinois. Forestry Circular No. 1.

Miller, Robt. B.

19:(). Fire prevention in Illinois forests. Forestry Circular No. ?.

1923. First report on a forestry survey of Illinois. Tol. XIV, Art. S.

Chapman, Herman H., and Miller, Robert B.

1924. Second report on a forest survey of Illinois. The economics of forestry in the state. Vol. XV, Art. 3.

Telford, C. I.

1926. Thind report on a forest survey of lllinois. (A woodland inventory, including growth and yield studies). Tol. XVI. Art. 1.

19:6. Brownfield Woods: at remmant of the original Illinois forest. Forestry Circular No. 3.

1926. Wood as a crop in lllinois. Forestry Circular No. $t$. 


\section{Appendi.x $F$}

\section{Services Offered to Woodland OWNers in Illinois}

The Natural History Survey, as a branch of the State Government, is prepared to help farmers and other woodland owners in the following ways:

(1) Instruction through correspondence, or by personal visit if necessary, in proper methods of thinning and developing natural woodlands to their highest productive capacity.

(2) Advice as to cutting trees to the best advantage for various purposes.

(3) Information on means of marketing wood products from any point in the State to such users as furniture factories, veneer plants, railroads, mines, car shops, pulpwood factories, companies using piling, dealers in cordwood, and others.

(4) Estimation of costs of manufacturing various wood products and costs of transportation to various markets.

(5) Identification of tree diseases and insect enemies, when specimens are sent to the Natural History Survey, and advice on methods of eradicating pests.

(6) Advice through correspondence, or by personal visit if necessary, to those who desire to plant waste lands, as to the proper species of trees suited to the soils and to the special purposes of the plantations.

(7) Suggestions for solving problems in the protection of woodlands against fire.

(8) Co-operation with other State agencies in all matters related to forestry.

In this connection, the Natural History Survey also pursues the following aims :

(a) To take account of the value of woodlands, existing or proposed. for recreational uses, not only by the inhabitants of the larger cities of the State, but also by the country people and the inhabitants of the smaller towns, whose home surroundings are often oppressively monotonous.

(b) To consider the uses of forests as preserves of the primitive life of the State, of great interest and value to the stuclent of science and his teacher and to the lovers of wild life.

(c) To co-ordinate the forest policy of the State with the novement for the establishment of a system of State parks.

Address inquiries to: Forester, State Natural History Survey, Urbana, Illinois. 